University at Buffalo School of Law

Digital Commons @ University at Buffalo School of Law

\title{
The Constitutionalization of Parole: Fulfilling the Promise of Meaningful Review
}

Alexandra Harrington

University at Buffalo School of Law

Follow this and additional works at: https://digitalcommons.law.buffalo.edu/journal_articles

Part of the Criminal Procedure Commons, Juvenile Law Commons, and the Law Enforcement and Corrections Commons

\section{Recommended Citation}

Alexandra Harrington, The Constitutionalization of Parole: Fulfilling the Promise of Meaningful Review, 106 Cornell L. Rev. 1173 (2021).

Available at: https://digitalcommons.law.buffalo.edu/journal_articles/1031

\section{C) ${ }_{\text {COPYRIGHT }}^{\text {N }}$}

This Article is brought to you for free and open access by the Faculty Scholarship at Digital Commons @ University at Buffalo School of Law. It has been accepted for inclusion in Journal Articles by an authorized administrator of Digital Commons @ University at Buffalo School of Law. For more information, please contact lawscholar@buffalo.edu. 


\title{
THE CONSTITUTIONALIZATION OF PAROLE: FULFILLING THE PROMISE OF MEANINGFUL REVIEW
}

\author{
Alexandra Harrington $\dagger$
}

Almost 12,000 people in the United States are serving life sentences for crimes that occurred when they were children. For most of these people, a parole board will determine how long they will actually spend in prison. Recent Supreme Court decisions have endorsed parole as a mechanism to ensure that people who committed crimes as children are serving constitutionally proportionate sentences with a meaningful opportunity for release. Yet, in many states across the country, parole is an opaque process with few guarantees. Parole decisions are considered "acts of grace" often left to the unreviewable discretion of the parole board.

This Article suggests a way to bring the current reality of parole closer to the Court's promise that parole can render life sentences constitutional. This Article considers how the Supreme Court's decisions in Graham, Miller, and Montgomery work to constitutionalize parole and change the conventional understanding of the board's determination. The Article also details the current standards of judicial review of parole board decisions. Because parole is now operating to make constitutional the sentences of people who were children at the time of the offense, the Eighth Amendment task placed on parole boards' shoulders necessitates substantive standards for the parole board, as well as judicial scrutiny of the board's determinations.

The Article proposes two essential reforms: first, a presumption of release on parole for people who were children at the time of the crime, absent a determination by clear and convincing evidence that they have not rehabilitated; and second, independent judicial review of the parole board decision to determine if the evidence supports defeating the presump-

$\dagger$ Associate Professor of Law and Director, Criminal Justice Advocacy Clinic, University at Buffalo School of Law. Thank you to Kristen Bell, Kiel BrennanMarquez, Renée Burbank, Fiona Doherty, Paul Linden-Retek, Judith Resnik, Sarah Russell, Emma Sokoloff-Rubin, Anna VanCleave, and Carly Zubrzycki for assistance in developing this project and for comments on earlier drafts. I am also grateful for feedback provided at the AALS Clinical Conference Works in Progress session-and in particular by Professor Kim Thomas, the Clinical Law Review Writers' Workshop, and the Yale ACS Progressive Scholarship Workshop. 
tion that life in prison is disproportionate for the vast majority

of people who committed crimes as children.

INTRODUCTION ............................ 1174

I. BACKGROUND ON RECENT JUVENILE SENTENCING LAW AND LEGISLATION ...................... 1179

A. Overview of Supreme Court Decisions on Sentencing Juveniles in Adult Court ........ 1179

B. Overview of State Responses: Fixing Sentences Through the Courts or Through Parole Review ........................... 1184

II. The TRAditional Understanding of PAROLE AND Judicial REVIEW of PAROlE DECISIONS . . . . . . . . . 1190

A. Parole as a Discretionary, Subjective Determination...................... 1190

B. Judicial Review of Traditional Parole Release Decisions ............................ 1194

III. GRAHAM, MiLler, MontGomery, AND THE ChANGing NATURE OF THE PAROlE DETERMINATION .......... 1199

A. The Constitutional Interest in the Parole Board's Decision ......................... 1199

B. A Hope of Release .................... 1202

C. How the Eighth Amendment Interest in Parole Changes the Nature of the Hearing. ......... 1204

D. Proposed Standard for Parole Board Review of Juvenile Parole Hearings: Presumption of Release ............................ 1204

IV. JUdiCIAL REVIEW OF JUVENILE PAROLE DETERMINATIONS ..................... 1215

A. The Case for Judicial Review ........... 1215

B. Review Beyond Procedural Due Process Compliance ....................... 1220

C. Proposed Standard for Judicial Review: Independent Review .................. 1225

\section{INTRODUCTION}

Almost 12,000 people in the United States are serving life sentences for crimes that occurred when they were children. ${ }^{1}$ Most of those people are reliant on the parole system to ensure that they will not in fact spend the rest of their lives in prison. In other words, an administrative parole board, rather than a

1 Youth Sentenced to Life Imprisonment, SENTENCING PROJECT (Oct. 8, 2019), https://www.sentencingproject.org/publications/youth-sentenced-life-imprisonment/ [https://perma.cc/L4PP-UJAQ]. 
sentencing or reviewing court, will determine how long they will actually spend behind bars. The Supreme Court has endorsed parole as a mechanism to ensure that people who committed crimes as children are serving constitutionally proportionate sentences with a meaningful opportunity for release. Yet, in many states across the country, parole is an opaque process with few guarantees. Individuals may be denied parole for reasons-for example, the nature of the offense-that were set in stone at the time the crime took place. Parole applicants may have no recourse for hearings that fail to provide meaningful consideration and may be denied access to judicial review. This Article suggests a way to bring the current reality of parole closer to the Court's promise that parole can render life sentences constitutional. I propose a presumption of release on parole for people who were children at the time of the crime, as well as judicial review of parole board denials to ensure that these individuals are not forced to serve a disproportionate sentence in prison.

In the last decade, the Supreme Court issued a series of decisions giving children sentenced to life in prison hope of a future beyond bars. First, in 2005 the Court in Roper v. Simmons held that the Eighth and Fourteenth Amendments forbid the death penalty for individuals who were under age eighteen at the time of their crime. ${ }^{2}$ Then, in 2010 in Graham $v$. Florida, the Court found that life without parole is an unconstitutional sentence for someone under age eighteen convicted of a nonhomicide crime, concluding that the State must "give defendants like Graham some meaningful opportunity to obtain release based on demonstrated maturity and rehabilitation." 3 Following closely on the heels of Graham, in 2012 the Court in Miller $v$. Alabama prohibited mandatory life without parole for juveniles, regardless of the offense. ${ }^{4}$

In 2016, Montgomery $v$. Louisiana made Miller's prohibition retroactive, holding that "Miller announced a substantive rule of constitutional law." 5 The Court continued: "A State may remedy a Miller violation by permitting juvenile homicide offenders to be considered for parole, rather than by resentencing them." 6 The Court asserted, without further analysis, that "[a]llowing those offenders to be considered for parole ensures

2 Roper v. Simmons, 543 U.S. 551, 578 (2005).

3 Graham v. Florida, 560 U.S. 48, 74-75 (2010).

4 Miller v. Alabama, 567 U.S. 460, 465 (2012).

5 Montgomery v. Louisiana, 136 S. Ct. 718, 736 (2016).

6 Id. 
that juveniles whose crimes reflected only transient immaturity-and who have since matured-will not be forced to serve a disproportionate sentence in violation of the Eighth Amendment." 7 This statement appears to presume that someone who demonstrates to a parole board that his juvenile crimes reflected only transient immaturity will not serve a sentence of life in prison. Yet, the Court's vague promise leaves unanswered the important question of what standards, if any, juvenile parole hearings must satisfy in order to comply with Miller's constitutional requirements.

The Court's most recent decision in Jones $v$. Mississippi complicates the landscape. In that case, the Court held that a finding of permanent incorrigibility is not required before sentencing a juvenile to life without parole. ${ }^{8}$ In some ways perhaps Jones changes little: the Court explicitly said that it leaves Miller and Montgomery intact. ${ }^{9}$ The decision did not address parole or back-end review of sentences but rather focused on the front-end sentencing decision. ${ }^{10}$ Yet, Jones also hollowed the earlier precedent into an unrecognizable shell of itself, insisting that sentencing discretion is all that is constitutionally required. ${ }^{11}$ This Article proceeds by taking the Court at its word that it did not overrule Miller and Montgomery ${ }^{12}$ and by asking what those decisions might have to say about parole release determinations. This Article proposes that, notwithstanding the Jones decision, states take seriously the call to make sentencing and parole meaningful for people who were children at the time of the crime.

Jurisdictions have reacted to the Supreme Court's decisions in varied ways. Many states have responded by providing parole eligibility for individuals convicted as juveniles. ${ }^{13}$ Despite variations in parole standards and procedures, courts across the country have treated parole eligibility as a curative fix for sentences that fail to account for the defendant's youth and youth-related mitigation. Indeed, the availability of parole resulted in the dismissal of one of the most recent juvenile sentencing case in which the Supreme Court granted certio-

7 Id.

8 Jones v. Mississippi, 141 S. Ct. 1307, 1319 (2021).

9 Id. at 1321.

10 See, e.g., id. at 1313 (concluding that a "discretionary sentencing system is both constitutionally necessary and constitutionally sufficient”).

11 Id.

12 This takes up the invitation of the dissent to "hold this Court to its word." Id. at 1337 (Sotomayor, J., dissenting).

13 See infra subpart I.B. 
rari. ${ }^{14}$ In Mathena $v$. Malvo, the Court took up the question whether Montgomery can appropriately be understood as expanding Miller. ${ }^{15}$ After the Virginia legislature reinstated parole for people who were under age eighteen at the time of the crime, ${ }^{16}$ the Court dismissed the case, ${ }^{17}$ affirming the idea that the availability of parole fixes constitutional violations inherent in a life sentence for someone who was a child at the time of the crime. Other courts have similarly rejected, based on parole eligibility, claims regarding the constitutionality of a defendant's sentence. ${ }^{18}$

Courts have been loath to interfere in parole boards' decision making. This Article compiles, in all fifty states, the standards for courts' review of parole board decisions. These standards skew heavily towards deference to the boards' "expertise." 19 I question whether the same deference that courts give to parole board determinations generally ought to apply in the context of juvenile parole hearings. For individuals who were juveniles at the time of the crime, the parole board is now making a constitutional determination-whether life in prison is a proportionate punishment for this individual. I argue that reasons for deferring to the boards' expertise do not apply in the juvenile parole context.

What, then, should a court's review of a parole release determination look like? One possible means to vindicate rights at a juvenile parole hearing would be to rely on procedu-

14 See Malvo v. Mathena, 893 F.3d 265 (4th Cir. 2018), cert. granted, 139 S. Ct. 1317 (2019) (mem.), and cert. dismissed, 140 S. Ct. 919 (2020) (mem.).

15 See Petition for Writ of Certiorari at i, Mathena v. Malvo, 139 S. Ct. 1317 (2019), cert. granted, 139 S. Ct. 1317 (2019) (mem.), and cert. dismissed, $140 \mathrm{~S}$. Ct. 919 (2020) (mem.) (No. 18-217) (framing the question presented as whether Montgomery can "properly be interpreted as modifying and substantively expanding" the rule in Miller).

16 VA. Code AnN. § 53.1-136 (West), VA. CodE AnN. § 53.1-165.1 (West), 2020 Va. Acts ch. 2.

17 Mathena v. Malvo, 140 S. Ct. 919, 919 (2020) (mem.).

18 For example, in Connecticut, where I practiced, the state supreme court relied on the availability of parole under newly enacted state legislation to determine that the defendant's sentence "no longer falls within the purview of Miller." State v. Delgado, 151 A.3d 345, 351-52 (Conn. 2016); see also State v. McCleese, 215 A.3d 1154, 1197 (Conn. 2019) (rejecting a related claim on state constitutional grounds). Other states have adopted similar analyses. See, e.g., People v. Franklin, 370 P.3d 1053, 1054 (Cal. 2016) (finding that eligibility for parole after twenty-five years in prison mooted constitutional claim under Miller); State ex rel. Jenkins v. State, 2017-0302, p. 1 (La. 8/31/18); 252 So. 3d 476, 476 (concluding that no resentencing necessary because relator was parole-eligible); Manley v. State, No. 63120, 2016 WL 1335379, at*1 (Nev. Apr. 1, 2016) (concluding that parole eligibility provides any relief afforded by Miller).

19 See infra subpart II.B. 
ral protections. Indeed, some jurisdictions have instituted rights to counsel, to an in-person hearing, to present evidence, and to receive a list of reasons for denial. These are important protections, to be sure. But, alone, they do not prevent the board from forcing someone who demonstrates maturity and rehabilitation to serve life in prison.

This Article proposes that the Eighth Amendment has something to say about the substance of the parole board's decision and not only about the process by which it reaches its determination. Montgomery means that if the State chooses not to resentence someone serving life in prison for a crime committed as a juvenile, it must provide an opportunity for parole. Similarly, if a juvenile was sentenced or resentenced to life-which in some states includes long, term-of-year sentences-with parole, the availability of parole is ostensibly what makes the sentence Graham- and Miller-compliant. In these instances, the law presumes that parole eligibility prevents the sentence from being unconstitutional.

The question, then, is whether the opportunity for something called "parole" is sufficient to fulfill the intent of these decisions or whether we must critically revise the conventional concept of parole. This Article proposes an understanding of Graham, Miller, and Montgomery as together signifying that people who were juveniles at the time of the crime have a constitutional interest in the parole board's determination. In order for juvenile parole hearings to perform the constitutional function the Court assigns to them, the board should grant release unless it determines by clear and convincing evidence that the juvenile parole applicant has not matured and rehabilitated. A court must be able to review this decision to independently determine whether the evidence justifies a denial-that is, whether the constitutional question was answered correctly.

This Article is divided into the following parts. Part I provides an overview of the recent Supreme Court decisions on juvenile sentencing as they address the importance of rehabilitation, the need for a meaningful opportunity for release, and the possibility of parole as a constitutional remedy for a sentencing violation. This section also details the state legislative and judicial responses to the Court's decisions. Part II assesses the traditional understanding of the parole board's decision and presents research on the standards of judicial review of parole board decisions in all fifty states. Part III makes the case that Graham, Miller, and Montgomery constitutionalize parole and transform it from a discretionary, subjective determi- 
nation into a vindication of a substantive, Eighth Amendment right. This Part proposes a presumption of release for juvenile parole applicants. Part IV examines the case for heightened judicial review of juvenile parole determinations and proposes a standard of review that focuses on the board's decision and whether the evidence supports overcoming the presumption of rehabilitation.

\section{I}

BACKGROUND ON RECENT JUVENILE SENTENCING LAW AND

\section{LEGISLATION}

A. Overview of Supreme Court Decisions on Sentencing Juveniles in Adult Court

Since the Court issued its decision in Roper $v$. Simmons over a decade ago, much attention has been given to the Court's line of cases addressing juvenile sentencing. This subpart provides a brief overview of the cases and focuses particularly on the aspects that address the possibility for rehabilitation and the need for an opportunity for release.

In 2005 the Court decided Roper $v$. Simmons, holding the death penalty unconstitutional for those whose crimes occurred when they were under age eighteen. ${ }^{20}$ The Court reasoned that juveniles "cannot with reliability be classified among the worst offenders" because of certain characteristics inherent in youth: immaturity, heightened vulnerability to peer pressure and negative influences, and capacity for change. ${ }^{21}$ The Court emphasized that youth is mitigating particularly because the "signature qualities of youth are transient." 22 In other words, as people age, their propensity for impulsive and reckless behavior, as well as their susceptibility to outside pressures, will diminish.

In 2010 in Graham v. Florida, the Court held that life without parole is unconstitutional for a juvenile convicted of a nonhomicide crime. ${ }^{23}$ While analyzing the penological justifications for a life without parole sentence, the Court reasoned that such a penalty forecloses the possibility of rehabilitation. ${ }^{24}$ The Court explained: "By denying the defendant the right to reenter the community, the State makes an irrevocable judgment about that person's value and place in society. This judg-

20 Roper v. Simmons, 543 U.S. 551, 578 (2005).

21 Id. at 569-70.

22 Id. at 570.

23 Graham v. Florida, 560 U.S. 48, 74-75 (2010).

24 See id. at 74. 
ment is not appropriate in light of a juvenile nonhomicide offender's capacity for change and limited moral culpability." 25 The Court ultimately concluded that because of juveniles' diminished culpability and capacity for rehabilitation, the State cannot incarcerate a juvenile convicted of a nonhomicide offense without a meaningful chance at life outside of prison. While the State need not "guarantee eventual freedom," it must provide "some meaningful opportunity to obtain release based on demonstrated maturity and rehabilitation." 26

In 2012 Miller $v$. Alabama expanded on the Graham decision and prohibited mandatory life without parole for juveniles, regardless of the offense. ${ }^{27}$ The Court emphasized that Graham's pronouncements about children's inherent characteristics and vulnerabilities apply to all children regardless of the offense of conviction. ${ }^{28}$ The Court concluded that sentencing courts must consider youth-related mitigation "before imposing the harshest possible penalty for juveniles." 29 A sentencing scheme that fails to account for youth "poses too great a risk of disproportionate punishment."30

In 2016 in Montgomery $v$. Louisiana, the Court held that Miller's prohibition applied retroactively because it was "a substantive rule of constitutional law." 31 The Court reasoned that Miller's rule is that a sentence of life without parole "is excessive for all but 'the rare juvenile offender whose crime reflects irreparable corruption." "32

The Court went on to address the states' concerns that they would be subject to a flood of resentencing hearings should Miller apply to convictions that were final. ${ }^{33}$ The Court reassured states that they would not be required to relitigate every single life-without-parole sentence. Rather, states could remedy the constitutional violation that occurred at sentencing by providing people who were children at the time of the crime with parole eligibility. The Court explained:

Allowing those offenders to be considered for parole ensures that juveniles whose crimes reflected only transient immaturity-and who have since matured-will not be forced to

$25 I d$.

26 Id. at 75.

27 Miller v. Alabama, 567 U.S. 460, 465 (2012).

28 See id. at 471-73.

29 Id. at 489.

30 Id. at 479.

31 Montgomery v. Louisiana, 136 S. Ct. 718, 736 (2016).

32 Id. at 734 (quoting Miller, 567 U.S. at 479-80).

33 See id. at 736. 
serve a disproportionate sentence in violation of the Eighth Amendment. . . . Those prisoners who have shown an inability to reform will continue to serve life sentences. The opportunity for release will be afforded to those who demonstrate the truth of Miller's central intuition-that children who commit even heinous crimes are capable of change. ${ }^{34}$

So, the Court assumed, someone who demonstrates to the parole board that they have indeed reformed will not "continue to serve [a] life sentence[ ]." 35 The Court concluded that people who were children at the time of the crime "must be given the opportunity to show their crime did not reflect irreparable corruption; and, if it did not, their hope for some years of life outside prison walls must be restored." 36 The Court thus sanctioned the spate of state legislative fixes granting parole eligibility to individuals who were sentenced to life in prison for crimes committed as juveniles.

In Mathena $v$. Malvo, which has been referred to colloquially as the "D.C. sniper case" because of the infamous crime for which the petitioner was convicted,37 the Supreme Court seemed poised to explain how Montgomery ought to be interpreted. ${ }^{38}$ The Court was presented with the question whether Montgomery can "properly [be] interpreted as modifying and substantially expanding the very rule whose retroactivity was in question."39 Mathena $v$. Malvo involved a juvenile who was sentenced to life without parole in Virginia, where the sentencing options for capital murder were death or life imprisonment. ${ }^{40}$ The Fourth Circuit held that Mr. Malvo was entitled to resentencing, under an interpretation of Miller that "the Eighth Amendment bars life-without-parole sentences for all but those rare juvenile offenders whose crimes reflect permanent incorri-

34 Id.

35 Id.

36 Id. at 736-37.

37 See, e.g., Amy Howe, Argument Analysis: "D.C. Sniper" Case Could Hinge on Kavanaugh, SCOTUSBLOG (Oct. 16, 2019, 4:28 PM), https:// www.scotusblog.com/2019/10/argument-analysis-d-c-sniper-case-could-hingeon-kavanaugh/ [https://perma.cc/Y4V5-YVDZ] (using "D.C. sniper case" to refer to Mathena $v$. Malvo).

38 See Petition for Writ of Certiorari, supra note 15, at i (presenting the question whether Montgomery can "properly be interpreted as modifying and substantively expanding" the rule in Miller).

39 Brief for Petitioner at i, Mathena v. Malvo, 193 S. Ct. 1317 (2019), cert. granted, 139 S. Ct. 1317 (2019) (mem.), and cert. dismissed, 140 S. Ct. 919 (2020) (mem.) (No. 18-217).

40 Brief for Respondent at 8-10, Mathena v. Malvo, 193 S. Ct. 1317 (2019), cert. granted, 139 S. Ct. 1317 (2019) (mem.), and cert. dismissed, 140 S. Ct. 919 (2020) (mem.) (No. 18-217). 
gibility." 41 The court reasoned that the jury had no option to impose "a sentence less than life without parole" and was never instructed to determine whether the crimes "reflected irreparable corruption," which, the court explained, is a "prerequisite to imposing a life-without parole sentence[.]" 42 The Supreme Court granted certiorari and the Court heard argument in October 2019.43 In early 2020, however, the Virginia legislature enacted a law that reinstated parole, previously defunct in the Commonwealth, for people who were under age eighteen at the time of the crime. ${ }^{44}$ Based on this change, the parties filed a stipulation of dismissal and the Court dismissed the case on February 26, 2020. ${ }^{45}$ While postponing the question of how the Court might clarify its earlier decisions, the dismissal in Malvo affirms the idea that the availability of parole can fix the Eighth Amendment violations inherent in a life sentence for someone who was under age eighteen at the time of the crime. As soon as Mr. Malvo became eligible for parole, the parties and the Court agreed that the constitutional arguments were moot.

Most recently, the Supreme Court addressed whether Miller and Montgomery require a judge to make a finding of permanent incorrigibility before sentencing a juvenile to life without parole. ${ }^{46}$ In Jones $v$. Mississippi, decided in 2021 , the Court rejected the petitioner's argument and held that a finding of permanent incorrigibility was not required. ${ }^{47}$ The Court asserted that a discretionary sentencing scheme is both "constitutionally necessary and constitutionally sufficient." 48 In rendering its decision, the Court emphasized that it was not overruling prior precedent; rather its decision "carefully follow[ed] both Miller and Montgomery." 49

Yet, while claiming fidelity to earlier precedent and citing to portions of Montgomery that address Miller's substantive requirements, ${ }^{50}$ the Court's decision reduced Miller to a procedu-

41 Malvo v. Mathena, 893 F.3d 265, 274 (4th Cir. 2018), cert. granted, 139 S. Ct. 1317 (2019) (mem.), and cert. dismissed, 140 S. Ct. 919 (2020) (mem.).

42 Id. at 275.

43 Mathena v. Malvo, 193 S. Ct. 1317 (2019), cert. granted, 139 S. Ct. 1317

(2019) (mem.), and cert. dismissed, 140 S. Ct. 919 (2020) (mem.).

442020 Va. Acts ch. 2.

45 Mathena v. Malvo, 140 S. Ct. 919 (2020) (mem.).

46 Jones v. Mississippi, 141 S. Ct. 1307 (2021).

47 Id. at 1319.

48 Id. at 1313.

49 Id. at 1321.

50 See, e.g., id. at 1315 n.2 (quoting Montgomery, 577 U.S. at 211 , "False That Miller did not impose a formal factfinding requirement does not leave States free to sentence a child whose crime reflects transient immaturity to life without parole. 
ral requirement that youth be considered at sentencing. ${ }^{51}$ The Court did so without addressing Miller's or Montgomery's pronouncements about the disproportionality of a life-without-parole sentence for the vast majority of people who were children at the time of the crime. Instead, the Jones Court magnified the role of discretion. Discretion, the Court explained, "allows the sentencer to consider the defendant's youth, and thereby helps ensure that life-without-parole sentences are imposed only in cases where that sentence is appropriate in light of the defendant's age." 52 Indeed, as the Court clarified, as long as the sentencer has discretion to consider youth, "the sentencer necessarily will consider the defendant's youth." 53

The decision occasioned both a forceful concurrence and dissent. In his concurrence Justice Thomas observed that the majority "[o]verrule[d] Montgomery in substance but not in name." ${ }^{4}$ While rebuking the Court for not going far enough in rejecting Montgomery, Justice Thomas lamented that Jones "fail[ed] to condemn Montgomery's expansion of Miller to an entire category of individuals." 55 By contrast, the dissent penned by Justice Sotomayor censured the Court for "distort[ing] Miller and Montgomery beyond recognition" and failing to address "Montgomery's clear articulation of Miller's essential holding." 56 Discretionary sentencing cannot be constitutionally sufficient, argued the dissent, because "[n]o set of discretionary sentencing procedures can render a sentence of LWOP constitutional for a juvenile whose crime reflects 'unfortunate yet transient immaturity'."57

What remains is a decision asserting that the holdings of Miller and Montgomery are intact while seeming to defang them

To the contrary, Miller established that this punishment is disproportionate under the Eighth Amendment.").

51 See, e.g., Jones, 141 S. Ct. at 1314 (quoting Miller as requiring "only that a sentencer follow a certain process"; Id. at 1316 (explaining that "Miller cited Roper and Graham for a simple proposition: Youth matters in sentencing."); Id. at

52 Id. at 1318.

53 Id. at 1319. This illustrates one of the decision's fundamental flaws: an ignorance-perhaps intentional-of the realities of sentencing. A sentencer given discretion could certainly choose to disregard youth-related mitigation, as appears to be happening in a number of states post-Montgomery. See Id. at 1333 (Sotomayor, J., dissenting) (citing Mississippi's greater-than-25\% life-without-parole resentencing rate and Louisiana's practice of imposing the sentence on most of the juvenile defendants sentenced since Miller was decided).

54 Id. at 1327 (Thomas, J., concurring).

55 Id. at $1327-28$.

56 Id. at 1330-31 (Sotomayor, J., dissenting).

57 Id. at 1332. 
entirely. ${ }^{58}$ This Article takes the Jones Court at its word that it did not overrule earlier decisions and offers a path forward to states who seek to provide meaning to Miller's and Montgomery's assertion that life in prison is disproportionate for the vast majority of juveniles.

\section{B. Overview of State Responses: Fixing Sentences Through the Courts or Through Parole Review}

Since the Supreme Court issued its decisions in Graham, Miller, and Montgomery, twenty-two states ${ }^{59}$ and the District of

58 Compare Id. at 1321 (asserting that the decision "carefully follows both Miller and Montgomery" and does not overrule them), and Id. at 1318 (seeming to affirm the substantive requirement of Miller: discretionary sentencing "helps ensure that life-without-parole sentences are imposed only in cases where that sentence is appropriate in light of the defendant's age"), with Id. at 1313 (asserting that discretion at sentencing is constitutionally sufficient to meet Eighth Amendment guarantees), and Id. at 1319 (implicitly rejecting the idea that a life without parole sentence may be disproportionate for certain people; explaining that one sentencer may decide youth-related mitigation requires a sentence less than life without parole while another sentencer on the same facts may "decide that life without parole remains appropriate").

59 Those states are Arkansas, California, Colorado, Connecticut, Delaware, Hawaii, Iowa, Kansas, Kentucky, Massachusetts, Nevada, New Jersey, North Dakota, Oregon, South Dakota, Texas, Utah, Vermont, Virginia, Washington, West Virginia, and Wyoming. See H.B. 2668, 83rd Leg., Reg. Sess. (Kan. 2010); State v. Sweet, 879 N.W.2d 811, 839 (Iowa 2016); State v. Bassett, 428 P.3d 343, 346 (Wash. 2018); S.B. 294, 91st Gen. Assemb., Reg. Sess. (Ark. 2017) (codified as amended at ARK. CODE ANN. § 5-4-108 (2017)); S.B. 394, 2017-2018 Reg. Sess. (Cal. 2017); S.B. 16-181, 70th Gen. Assemb., 2d Reg. Sess. (Colo. 2016); S.B. 796, 2015 Gen. Assemb., Jan. Sess. (Conn. 2015); S.B. 9, 147th Gen. Assemb., Reg. Sess. (Del. 2013); H.B. 2116, 27th Leg., Reg. Sess. (Haw. 2014); H. 4307, 188th Gen. Court (Mass. 2014); A.B. 267, 78th Sess. Assemb., Reg. Sess. (Nev. 2015); A. 373, 217th Leg. Assemb. (N.J. 2017); H.B. 1195, 65th Leg. Assemb., Reg. Sess. (N.D. 2017); S.B. 1008, 80th Legis. Assemb., Reg. Sess. (Or. 2019); S.B. 140, 2016 Leg., Reg. Sess. (S.D. 2016); S.B. 2, 83d Leg. (Tex. 2013); H.B. 405, 2016 Gen. Sess. (Utah 2016); H. 62, 73d Sess. (Vt. 2015); H.B. 35, 2020 Gen. Assemb., Reg. Sess. (Va. 2020); H.B. 4210, 81st Leg., 2d Sess. (W. Va. 2014); H.B. 23, 62d Leg., Gen. Sess. (Wyo. 2013). In addition, Alaska does not (and did not even before 2012) authorize a life without parole sentence. See AlaskA STAT. AnN. $\S \S 12.55 .015,12.55 .125$ (West 2020) (authorizing determinate sentences up to ninety-nine years for felony convictions). Someone convicted of first-degree murder under certain circumstances can be sentenced to a mandatory term of ninetynine years in prison, which does not carry parole eligibility. See ALASKA STAT. AnN. $\S \S$ 12.55.125(a), 33.16.090(a)(1)(A) (West 2020). However, no one in the state has been sentenced to life without parole for a crime committed as a juvenile. See No Life Sentences Without Parole for Juveniles in Alaska, AP NEWs (July 31, 2017), https://apnews.com/article/ad7e9c6756744b21b757d65cce39e6fb [https:// perma.cc/9GMZ-SATP]. Maine, New Mexico, New York, and Rhode Island do not impose the sentence in practice. See Maine Has Long Avoided Life Sentences for Juveniles, AP NEws (July 31, 2017), https://apnews.com/article/ 85fla838418543ebb299b218920a9903 [https://perma.cc/K28S-P55B] (reporting that the state attorney general's office is unaware of any juvenile life without parole sentences in the state); Lawyer: New Mexico Man Serving De Facto Life 
Columbia 60 have prohibited imposition of a life-without-parole sentence on someone who was under age eighteen at the time of the crime. Six of those states have made the prohibition retroactive, ${ }^{61}$ while in most of the states the ban on life without parole operates only prospectively.

Some states have elected to have courts review long sentences for people who were children at the time of the offense. Thirteen states have provided for automatic resentencing of juveniles who were previously sentenced to life without parole. ${ }^{62}$ The following five jurisdictions allow people who were under age eighteen at the time of the offense to petition the court for review of their sentence after they have served a cer-

Without Parole, AP NEws (July 31, 2017), https://apnews.com/article/ce3b3ba 805b04e24alff86daf07704fl [https://perma.cc/5U7E-8F4S] (stating that corrections officials report no one serving life without parole for juvenile offenses); New York Now Considers Youth as a Factor for Inmates' Parole, AP NEWs (July 31, 2017), https://apnews.com/article/3ad299fe4cd04150806c84aa 1378eed 1 [https://perma.cc/9E5Y-FMJH] (reporting that "New York has not sentenced juveniles to life in prison without parole"); Rhode Island's Try to Ban Juvenile Life Without Parole Fails, AP NEWs (July 31, 2017), https://apnews.com/article/ 23440555f419449e8f374102d321ccae [https://perma.cc/ES52-QFQB] (reporting that Rhode Island "has never sought life without parole for a juvenile").

6063 D.C. Reg. 15312 (Dec. 16, 2016) (effective Apr. 4, 2017).

61 Those states are Arkansas, California, Colorado, Connecticut, Delaware, and Nevada. See Ark. S.B. 294; Cal. S.B. 394; Colo. S.B. 16-181; Conn. S.B. 796; Del. S.B. 9; Nev. A.B. 267.

62 The states that have provided for automatic resentencing are Alabama, Colorado, Florida, Illinois, Michigan, Mississippi, Nebraska, New Jersey, North Carolina, Pennsylvania, South Carolina, Tennessee, and Washington. Six state courts-Florida, Illinois, Mississippi, Nebraska, South Carolina, and Tennesseehad held before Montgomery was decided that Miller was retroactive. See Falcon v. State, 162 So. 3d 954, 964 (Fla. 2015); People v. Davis, 6 N.E.3d 709, 722 (Ill. 2014); Jones v. State, 122 So. 3d 698, 703 (Miss. 2013); State v. Mantich, 842 N.W.2d 716, 731 (Neb. 2014); Aiken v. Byars, 765 S.E.2d 572, 575 (S.C. 2014); Ex parte Maxwell, 424 S.W.3d 66, 75 (Tex. Crim. App. 2014). Five states decided, post-Montgomery, to resentence juveniles whose mandatory life-without-parole sentences had been final. Alabama and North Carolina did so through state supreme court decisions. See Ex parte Williams, 244 So. 3d 100, 101 (Ala. 2017); Wynn v. State, 246 So. 3d 163, 187-89 (Ala. Crim. App. 2016); State v. Perry, 794 S.E.2d 280, 281-82 (N.C. 2016). Colorado, Michigan, and Washington enacted legislation to provide for resentencing of those who were juveniles at the time of the crime. WASH. REV. CODE § 10.95.035(1) (2020) (noting that Washington also prospectively eliminated life without parole for individuals who were under age eighteen at the time of the offense); Colo. S.B. 16-181 (noting that Colorado also retroactively eliminated life without parole for people who were juveniles at the time of their crimes); S.B. 319, 97th Leg., Reg. Sess. (Mich. 2014). New Jersey and Pennsylvania have relied on resentencing without explicitly addressing Miller's remedy for individuals sentenced to life without parole. See, e.g., State v. Zuber, 152 A.3d 197, 202 (N.J. 2017) (remanding case involving life-without-parole sentence for resentencing); Commonwealth v. Jones, 135 A.3d 175, 175 (Pa. 2016) (per curiam) (remanding life-without-parole case on collateral review to trial court for resentencing); Commonwealth v. Williams, 133 A.3d 4, 4 (Pa. 2016) (per curiam) (same). 
tain number of years in prison. ${ }^{63}$ Florida provides for sentence review after fifteen to twenty-five years for people convicted of certain offenses. ${ }^{64}$ California allows some people sentenced to life without parole to petition the court for resentencing after fifteen years. ${ }^{65}$ Delaware allows juveniles sentenced to more than twenty years in prison to petition for sentence modification after twenty or thirty years, depending on the crime. ${ }^{66}$ North Dakota provides petitions for sentence reduction after twenty years in prison. ${ }^{67}$ The District of Columbia allows for sentence modifications after fifteen years. ${ }^{68}$

Meanwhile, other states have placed the responsibility for reviewing how long people should be in prison in the hands of the parole board. Seventeen states have responded to the $\mathrm{Su}-$ preme Court decisions by providing parole eligibility for juveniles. ${ }^{69}$ The timing for parole eligibility ranges from fifteen

63 This number includes Florida, which also provides for resentencing hearings for those serving mandatory life-without-parole sentences for crimes that occurred when they were juveniles. See Falcon, 162 So. 3d at 964. In addition, even before the recent Supreme Court decisions, Oregon provided "second look" hearings for individuals who were convicted in adult court of crimes that occurred when they were under age eighteen. OR. REV. STAT. ANN. § 420A.203(1) (West 2020). The statute provides that after the individual has served half the prison term, they are eligible for sentence review to determine if they should continue to serve the remainder of their term or should be conditionally released. Id.

64 FLA. STAT. ANN. § $921.1402(2)(\mathrm{a})-(\mathrm{c})$ (West 2020).

65 CAL. PENAL CODE \& 1170(2)(A)(i) (West 2020). California has also enacted parole provisions, as described below, specific to people who were under age eighteen at the time of the crime. See Cal. S.B. 394.

66 DEL. CoDE ANN. tit. 11, § 4204A(d)(1)-(2) (West 2020). The state also passed legislation providing for resentencing of juveniles serving mandatory life without parole sentences. Del. S.B. 9, § 6 .

67 N.D. CEnT. CODE ANn. § 12.1-32-13.1(a) (West 2020).

68 D.C. Code Ann. § 24-403.03 (West 2020). D.C. Act 21-568, which became effective April 4, 2017, provided for sentence review after the individual had served twenty years in prison. 63 D.C. Reg. 15312 (Dec. 16, 2016) (effective Apr. 4, 2017). The law was amended in 2018 to allow sentence modifications after fifteen years rather than twenty years. 66 D.C. Reg. 1627 (Jan. 30, 2019) (effective May 10, 2019). The amendments also changed the statutory language from the "court may" reduce a term of imprisonment to the "court shall" reduce a term of imprisonment. Id. (emphasis added).

69 Those states are Arizona, Arkansas, California, Colorado, Connecticut, Hawaii, Iowa, Louisiana, Massachusetts, Minnesota, Missouri, Nevada, Oregon, Virginia, Washington, West Virginia, and Wyoming. The most recent of these bills in Virginia was passed in February 2020. See CONN. GEN. STAT. § 54-125a(f) (2020); HAW. REV. STAT. §§ 706-656(1), 706-669(1) (West 2020); LA. STAT. ANN. § 15:574.4 (2020); LA. CODE CRIM. PROC. ANn. art. 878.1 (2020); WASH. REv. CODE ANN. $\S$ 9.94A.730 (LexisNexis 2020); Jackson v. State, 883 N.W.2d 272, 282 (Minn. 2016); State v. Mares, 335 P.3d 487, 498 (Wyo. 2014); H.B. 2593, 51st Leg., 2d Reg. Sess. (Ariz. 2014); S.B. 294, 91st Gen. Assemb., Reg. Sess. (Ark. 2017); S.B. 394, 2017-2018 Reg. Sess. (Cal. 2017); S.B. 16-180, 70th Gen. Assemb., 2d Reg. Sess. (Colo. 2016); S. File 448, 86th Gen. Assemb., 1st Sess. (Iowa 2015); S.B. 16, 2017 Leg., Reg. Sess. (La. 2017); H. 4307, 188th Gen. Court (Mass. 
to thirty years, depending on the state and the crime of conviction. Eight states have created new rules specific to juvenile parole hearings. Arkansas requires the parole board to consider, among other things, "[t]he hallmark features of youth . . . [s]ubsequent growth and increased maturity . . . [i]mmaturity . . . at the time of the offense."70 California's juvenile parole legislation was intended to require the board to "give great weight to the diminished culpability of youth as compared to adults, the hallmark features of youth, and any subsequent growth and increased maturity." 71 Colorado allows individuals with felony convictions for crimes committed as juveniles to petition for admission to a Department of Correction program, after which they can apply for early parole and will be presumed to meet the criteria for release if they have served a certain amount of time in prison. ${ }^{72}$ Connecticut requires the parole board to consider evidence of rehabilitation, taking into account, among other things, "the age and circumstances of such person as of the date of the commission of the crime or crimes, whether such person has demonstrated remorse and increased maturity."73 Missouri passed legislation mandating parole board consideration of "[e]fforts made toward rehabilitation" and "[t]he subsequent growth and increased maturity of the person." 74 Oregon directs the board to "consider and give substantial weight to the fact that a person under 18 years of age is incapable of the same reasoning and impulse control as an adult and the diminished culpability of

2014); S.B. 590, 98th Gen. Assemb., 2d Reg. Sess. (Mo. 2016); A.B. 267, 78th Sess. Assemb., Reg. Sess. (Nev. 2015); S.B. 1008, 80th Legis. Assemb., Reg. Sess. (Or. 2019); H.B. 35, 2020 Gen. Assemb., Reg. Sess. (Va. 2020); H.B. 4210, 81st Leg., 2d Sess. (W. Va. 2014); H.B. 23, 62d Leg., Gen. Sess. (Wyo. 2013). Colorado and Washington also provide for resentencing hearings for juveniles with mandatory life sentences. See § 9.94A.730; S.B. 16-180, 70th Gen. Assemb., 2d Reg. Sess. (Colo. 2016).

70 ARK. CODE ANN. § 16-93-621(b)(2)(B), (C), (E) (West 2020). Note that the Arkansas Supreme Court had previously held that Miller applies retroactively and mandates resentencing for juveniles sentenced to mandatory life without parole. See Kelley v. Gordon, 465 S.W.3d 842, 846 (Ark. 2015); Jackson v. Norris, 426 S.W.3d 906, 910-11 (Ark. 2013). The new parole legislation does not apply to defendants whose sentences were vacated for resentencing under Kelley and Jackson at the time of the legislation's enactment. See Harris v. State, 547 S.W.3d 64, 70-71 (Ark. 2018).

71 S.B. 394, 2017-2018 Reg. Sess. (Cal. 2017); see also CAL. PENAL CodE $\S 3051(\mathrm{f})(1)$ (West 2020) (requiring any evaluations or risk assessments used by the board to consider "the diminished culpability of youth as compared to that of adults, the hallmark features of youth, and any subsequent growth and increased maturity of the individual").

72 See Colo. Rev. STAT. ANN. § 17-34-102(4), (8)(a) (West 2020).

$73 \S 54-125 \mathrm{a}(\mathrm{f})$.

74 S.B. 590, 98th Gen. Assemb., 2d Reg. Sess. (Mo. 2016). 
minors as compared to that of adults." 75 Washington created a mechanism for individuals to petition for early release after twenty years in prison with a presumption that they will be released unless the board finds they are likely to violate the law. ${ }^{76}$ West Virginia enacted a statute that requires a parole board to consider "the diminished culpability of juveniles as compared to that of adults, the hallmark features of youth, and any subsequent growth and increased maturity of the prisoner during incarceration." 77

In states that have created parole eligibility provisions for people with juvenile offenses, some courts have explicitly held that such parole eligibility is a sufficient remedy for a Miller violation such that resentencing is not required. The California Supreme Court held in People $v$. Franklin that the legislative provision of parole after twenty-five years in prison mooted the juvenile defendant's constitutional claim under Miller. ${ }^{78}$ Significantly for the court, the California statute in question "requires the Board not just to consider but to "give great weight to the diminished culpability of juveniles as compared to adults, the hallmark features of youth, and any subsequent growth and increased maturity ...."79 The legislation, the court found, was "designed to ensure Ipeople who committed crimes as juveniles] will have a meaningful opportunity for release." 80 In analyzing Franklin's claim that a court rather than the administrative parole board should consider the relevance of his youth to sentencing, the court concluded that "Miller did not restrict the ability of states to impose life with parole sentences on juvenile offenders; such sentences necessarily contemplate that a parole authority will decide whether a juvenile offender is suitable for release." 81 In State $v$. Vera, the Arizona Appellate Court reached a similar conclusion, determining that legislation that reintroduced the possibility of parole for individuals who were under age eighteen at the time of the offense provided the "'meaningful opportunity' for release contemplated by Miller and Graham." 82 Parole had been eliminated in Arizona for crimes committed after 1994, but 2014 legislation rein-

\footnotetext{
75 OR. REV. STAT. ANN. § 144.397 (West 2019).

76 See WASH. REV. CODE ANN. § 9.94A.730 (LexisNexis 2020).

77 H.B. 4210, 81st Leg., 2d Sess. (W. Va. 2014).

78370 P.3d 1053, 1054 (Cal. 2016).

79 Id. at 1060 (quoting CAL. PENAL CODE § 4801(c) (West 2018)).

80 Id.

81 Id. at 1064.

82334 P.3d 754, 761 (Ariz. Ct. App. 2014) (quoting Graham v. Florida, 560 U.S. 48,75 (2010)).
} 
stated parole for individuals who were under age eighteen at the time of the crime. ${ }^{83} \mathrm{Mr}$. Vera argued that the new legislation was insufficient to cure the Miller violation that occurred when the sentencing court failed to consider his youth. ${ }^{84}$ The appellate court disagreed, finding that the legislation remedied Arizona's sentencing scheme sufficiently to comply with Miller and Graham. ${ }^{85}$ The court reasoned that "an opportunity for parole" was consistent with a "'meaningful opportunity' for release." 86

Yet, the question remains whether an opportunity for parole, without more, is sufficient to fulfill the Supreme Court's promise that only the rare, irreparably corrupt juvenile will serve life in prison, or whether the constitutionally mandated "meaningful opportunity to obtain release" 87 must look different-in process, in consideration, or in standard of reviewthan a traditional parole release determination. An examination of the traditional conception of parole can shed light on how the Court's recent decisions might alter that conventional understanding.

83 See H.B. 2593, 51st Leg., 2d Reg. Sess. (Ariz. 2014); S.B. 1049, 41st Leg., 1st Reg. Sess. (Ariz. 1993).

84 Vera, 334 P.3d at 756.

85 Id. at 761.

86 Id. (quoting Graham, 560 U.S. at 75); see also State v. McCleese, 215 A.3d 1154,1173 (Conn. 2019) (explaining that parole eligibility "is a meaningful, practical, and constitutionally sufficient remedy in light of the fact that no remedy can travel back in time and provide the defendant with a Miller compliant sentencing hearing at the time of his original sentencing”); State v. Delgado, 151 A.3d 345, 352 (Conn. 2016) (explaining that, under Miller, courts are only required to consider youth-related mitigation when imposing a sentence of life without parole); State ex rel. Jenkins v. State, 2017-0302, p. 1 (La. 8/31/18), 252 So. 3d 476, 476 (concluding that no resentencing necessary because parole eligibility remedies any Miller violation); Manley v. State, No. 63120, 2016 WL 1335379, at*1 (Nev. Apr. 1, 2016) (concluding that providing parole eligibility during petitioner's lifetime satisfies the relief afforded by Miller); Stevens v. State, 422 P.3d 741, 750-51 (Okla. Crim. App. 2018) (implicitly determining in post-conviction proceeding that if the State agrees to sentence with parole eligibility, resentencing is not required); State v. Scott, 416 P.3d 1182, 1187 (Wash. 2018) (relying on Montgomery, concluding that "the Washington Miller fix statute's parole provision cures the Miller violation in Scott's case").

87 Graham, 560 U.S. at 75. 
II

The Traditional Understanding of PAROle AND JUdiCIAL REVIEW OF PAROLE DECISIONS

\section{A. Parole as a Discretionary, Subjective Determination}

Parole emerged in the United States as a way "to encourage good behavior and to foster rehabilitation." 88 The earliest American experiment with parole dates to 1876 when administrators at the Elmira Reformatory in New York rewarded resident juveniles and young adults for good behavior with movement through progressive classification grades. ${ }^{89}$ Release to the community-under supervision of the institution's authorities-was possible upon demonstrating continued good behavior in the first classification. ${ }^{90}$ Beginning in the early twentieth century, states started to adopt indeterminate sentencing and parole regimes, and by 1942 every state and the federal government operated under such a scheme. ${ }^{91}$ These new systems allowed parole boards to determine when prisoners should be released from incarceration, while at the same time providing incentives for prisoners to "earn" early release. ${ }^{92}$ Parole was considered a matter of "special expertise," involving "release under supervision at a time that maximizes both the protection of the public and the individual's rehabilitation." 93 Though, in practice, parole often operated more as a system for reducing prison overcrowding and prisoner violence than as a system designed to encourage rehabilitation. ${ }^{94}$ At the peak of parole's ubiquity in 1977, seventy-two percent of U.S. prisoners who were released from prison were released on parole. ${ }^{95}$

A sea change came in the late 1970s, when critics challenged indeterminate sentencing and parole release as inconsistent, discriminatory, and ineffectual at reducing recidivism. ${ }^{96}$ Scholars advocated for a system with less focus on rehabilitation, which they argued was ineffective, and with

88 Kimberly Thomas \& Paul Reingold, From Grace to Grids: Rethinking Due Process Protection for Parole, 107 J. CRIM. L. \& CRIMINOLOGY 213, 217 (2017).

89 See Joan Petersilia, Parole and Prisoner Reentry in the United States, 26 CRIME \& JUST. 479, 488-89 (1999).

90 See id.

91 See id. at 489.

92 Thomas \& Reingold, supra note 88, at 217-18.

93 Jon O. Newman, William J. Genego, Peter D. Goldberger, \& Vicki C. Jackson, Parole Release Decisionmaking and the Sentencing Process, 84 YALE L.J. 810, 815 (1975) [hereinafter Parole Release Decisionmaking].

94 See Petersilia, supra note 89, at 490.

95 See id. at 489.

96 See id. at 492-93; Parole Release Decisionmaking, supra note 93, at 816. 
less parole board discretion, which they claimed led to disparities in sentencing among people convicted of the same offenses. ${ }^{97}$ Between 1976 and 1999, seventeen states entirely eliminated discretionary parole release. ${ }^{98}$ This change was accompanied by a move towards determinate sentencing and

97 See Petersilia, supra note 89 , at 494.

98 Arizona abolished parole for offenses committed on or after January 1, 1994, but reinstated parole for people who committed crimes as children. S.B. 1049, 41st Leg., 1st Reg. Sess. (Ariz. 1993); see also ARIZ. REV. StAT. AnN. $\S 13-716$ (2014) (asserting that a person sentenced to life imprisonment with the possibility of release for an offense committed before the person was eighteen years old is eligible for parole after reaching the minimum sentence "regardless of whether the offense was committed on or after January 1, 1994"); ARIZ. REV. STAT. ANN. § 41-1604.09 (2019) (providing that parole eligibility certification applies to "a person who commits a felony offense before January 1, 1994" and to a person "who is eligible for parole pursuant to § 13-716"). Delaware abolished parole for offenses committed after 1990. Del. Admin. Code Par 2 (2020) (Uncodified). Florida abolished parole for offenses committed after 1983. See Release Types: Parole, FLA. COMMISSION ON OFFENDER REV., https://www.fcor.state.fl.us/releasetypes.shtml [https://perma.cc/2R7B-EKHP] (last visited Sept. 16, 2020). Illinois abolished parole in 1978. See 38 ILL. COMP. STAT. 730/3-3-3(b) (2020). Indiana abolished parole for offenses committed after October 1977. See Indiana Parole Board, IND. DEP'T CORRECTION, https://www.in.gov/idoc/parole-services/paroleboard/ [https://perma.cc/U6KS-8Q4P] (last visited Sept. 16, 2020). Kansas abolished parole for those offenses committed on or after July 1, 1993. KAN. STAT. ANN. § 22-3717(d)(1) (2020). Maine abolished discretionary parole in 1976. ME. REV. STAT. ANN. tit. 34-A, § 5801 (1983). Minnesota abolished its discretionary parole system in 1980. See MinN. DEP'T OF CORRECTIONS, CORRECTIONS RETROSPECTIVE 1959-1999, at 12 (1999), https://mn.gov/doc/assets/docretro_tcm1089276272.pdf [https://perma.cc/Z9NL-KDCE] (last visited Oct. 17, 2020). North Carolina does not have parole for crimes that occurred after 1994. An Act to Provide for Structured Sentencing in North Carolina, 1993 N.C. Sess. Laws 2298, 2336. Ohio does not have discretionary parole for offenses committed on or after July 1, 1996. OHIO REv. CODE ANN. § 2967.13 (West 2020). Oregon abolished discretionary parole for offenses committed after November 1, 1989. OR. REV. STAT. ANN. \& 144.050 (West 2020). In 2019 Oregon reinstated parole for people who were under age eighteen at the time of the crime. S.B. 1008, 80th Legis. Assemb., Reg. Sess. (Or. 2019). Virginia abolished discretionary parole in 1995 and currently has a system of geriatric parole for prisoners over age sixty. S.B. 3001, 1994 Gen. Assemb., 2d Spec. Sess. (Va. 1994); see also VA. CODE ANN. § 53.1-40.01 (2020) (providing means for incarcerated people older than sixty to obtain parole). Virginia also reinstated parole for people who were under age eighteen at the time of the crime. H.B. 35, 2020 Gen. Assemb., Reg. Sess. (Va. 2020). Washington does not have parole for crimes committed after 1984 except in the cases of people who were under age eighteen at the time of the crime and for people convicted of certain sex offenses that occurred on or after September 1, 2001. WASH. REV. CODE ANN. §§ 9.94A.730, 9.95.110-9.95.116, 9.95.190 (West 2020). Wisconsin abolished parole for crimes committed after 1999. See Parole Information, ST. WIS. DEP'T CORRECTIONS, https://doc.wi.gov/Pages/VictimServices/ParoleInformation.aspx [https://perma.cc/84D3-QDXU] (last visited Oct. 17, 2020). I am also counting Connecticut, Colorado, and Mississippi, which abolished discretionary parole but later reinstated it for at least some offenses. See Andres F. Rengifo \& Don Stemen, The Unintended Effects of Penal Reform: African American Presence, Incarceration, and the Abolition of Discretionary Parole in the United States, 61 CRIME \& DELINQ. 719, 736 (2012). 
longer prison terms. ${ }^{99}$ All states now operate with mandatory minimum sentencing schemes, and most states require people convicted of violent offenses to serve eighty-five percent of their sentence in prison, limiting the discretion of the parole boards. ${ }^{100}$

Currently, forty states ${ }^{101}$ have some form of discretionary parole available for at least some people. ${ }^{102}$ Discretionary parole release still accounts for at least thirty percent of all prison releases in 2012.103 Efforts to limit inconsistent parole decisions persist: most modern parole boards rely on guidelines or other decision-making tools in making release decisions. ${ }^{104}$ The board's inquiry generally focuses on the parole applicant's dangerousness should they be released. ${ }^{105}$

Traditionally, courts have understood parole as a discretionary, subjective, equity-like process. It has been termed "an act of grace." 106 In its 1979 Greenholtz decision, the Supreme

99 See Petersilia, supra note 89, at 494.

100 See id. at 497.

101 Alabama, Alaska, Arizona, Arkansas, California, Colorado, Connecticut, Georgia, Hawaii, Idaho, Iowa, Kentucky, Louisiana, Maryland, Massachusetts, Michigan, Mississippi, Missouri, Montana, Nebraska, Nevada, New Hampshire, New Jersey, New Mexico, New York, North Dakota, Oklahoma, Oregon, Pennsylvania, Rhode Island, South Carolina, South Dakota, Tennessee, Texas, Utah, Vermont, Virginia, Washington, West Virginia, and Wyoming.

102 I am including in this count states that only have parole eligibility for people who were under eighteen years old at the time of the crime. Those states are Arizona, Oregon, Virginia, and Washington (in addition to having parole eligibility for people who were juveniles at the time of the offense, Washington also excepts people convicted of certain sex offenses that occurred after 2001 from its post-1984 parole ban). I am also including states that seriously limit discretionary parole eligibility based on the offense of conviction. These states are California and New Mexico. New Mexico has not had discretionary parole since 1979 except for prisoners serving life sentences. N.M. STAT. ANN. § 31-21-10(A) (West 2020). Similarly, California limits discretionary parole consideration to individuals sentenced to indeterminate life in prison and for a few other specified offenses. CAL. PENAL CODE § 3046 (West 2020).

103 See E. ANn CARson, U.S. Dep’t of Justice: Bureau of Justice Statistics, PRISONERS IN 2018, at 13 (2020), https://www.bjs.gov/content/pub/pdf/p18.pdf [https://perma.cc/NC26-JQX6] (showing 614,844 prisoners released in 2018 from state and federal facilities); DANIELLE KAEBLE \& MARIEL ALPER, U.S. DEP'T OF Justice: Bureau of Justice Statistics, Probation and Parole in the United States, 2017-2018, at 23 (2020), https://www.bjs.gov/content/pub/pdf/ppus 1718.pdf [https://perma.cc/MJ55-Q9ZA] (showing 192,296 discretionary parole releases in 2018 from state and federal facilities); see also Thomas \& Reingold, supra note 88, at 239 ("Discretionary release by parole boards still accounts for at least onethird and possibly close to half of all prison releases.").

104 See Thomas \& Reingold, supra note 88, at 242.

105 See Richard A. Bierschbach, Proportionality and Parole, 160 U. PA. L. REV. 1745, 1751 (2012).

106 See, e.g., Daniel S. Medwed, The Innocent Prisoner's Dilemma: Consequences of Failing to Admit Guilt at Parole Hearings, 93 IowA L. REV. 491, 493 
Court explained that states may provide parole but are not obliged to do so. ${ }^{107}$ The Court described parole as a system in which "few certainties exist" and in which "the choice involves a synthesis of record facts and personal observation filtered through the experience of the decisionmaker and leading to a predictive judgment as to what is best both for the individual inmate and for the community." 108 In other words, the Court understood that the parole determination depends very much on the subjective assessments of the individual board members. Such subjectivity and lack of certainty about the parole process results in few guarantees about outcomes. Indeed, the Court emphasized that "[t]here is no constitutional or inherent right of a convicted person to be conditionally released before the expiration of a valid sentence." 109 Parole is an "equity' type judgment that cannot always be articulated in traditional findings." 110

In Greenholtz, the Court addressed whether the Fourteenth Amendment's Due Process Clause applies to parole release decisions. Nebraska prisoners who had been denied parole filed a $\S 1983$ class action alleging that the parole board's procedures violated due process requirements. ${ }^{111}$ The question was whether individuals appearing before the Nebraska parole board have a liberty interest in parole that would trigger a due process analysis. The Court of Appeals for the Eighth Circuit had found that prisoners seeking parole had a liberty interest akin to the liberty interest held in Morrissey $v$. Brewer ${ }^{12}$ to be at stake in parole revocation decisions. ${ }^{113}$ The Supreme Court reversed. Parole revocation decisions, the Court explained, involve a deprivation of liberty that discretionary parole decisions do not. ${ }^{114}$

In reaching this decision, the Court highlighted the contrasts between discretionary parole and parole revocation decisions. These distinctions centered on the idea that parole is more subjective and that, generally speaking, there is nothing a

(2008) ("The granting of parole in the criminal justice system is often viewed as an act of grace: the dispensation of mercy by the government to an individual prisoner deemed worthy of conditional release prior to the expiration of his sentence.").

107 Greenholtz v. Inmates of Neb. Penal \& Corr. Complex, 442 U.S. 1, 7 (1979).

108 Id. at 8.

109 Id. at 7.

110 Id. at 8.

111 Id. at 3-4.

112408 U.S. 471,480 (1972).

113 Greenholtz, 442 U.S. at 5-6, 16.

114 Id. at 9. 
parole applicant can prove that would require he be released. ${ }^{115}$ The protections required at parole revocation hearings are necessary to ensure that revocation determinations are "based on verified facts" and "an accurate knowledge of the parolee's behavior."116 By contrast, "the possibility of parole provides no more than a mere hope that the benefit will be obtained," and such hope, the Court held, falls outside the protections of due process. ${ }^{117}$ In so holding, the Court relied on the subjective, discretionary nature of the parole decisionmaking process. The parole determination, the Court explained, "is more subtle" and depends on many "purely subjective appraisals by the Board members based upon their experience with the difficult and sensitive task of evaluating the advisability of parole release." 118 "The decision turns on a "discretionary assessment of a multiplicity of imponderables, entailing primarily what a man is and what he may become rather than simply what he has done." 119 Unlike revocation, "there is no set of facts which, if shown, mandate a decision favorable to the individual." 120

The Greenholtz description and evaluation of the nature of parole has endured in courts' current analyses. Because parole has been understood as a wholly discretionary assessment entrusted to the wisdom of the parole board, courts have been reluctant to interfere with the boards' determinations. ${ }^{121}$ As David Ball wrote, "a parole board is free to deny parole for whatever reason, on whatever facts, for however long." 122 The next subpart analyzes the standards of review for parole denials in all fifty states. While the analysis does not quite bear out that boards can deny parole for any reason, reviewing courts do impose few restrictions on the manner of and reasons for parole denial.

\section{B. Judicial Review of Traditional Parole Release Decisions}

Access to judicial review of a parole board's decision and the standard for the court's review vary across states. Informa-

\footnotetext{
115 See id. at 9-10.

116 Morrissey, 408 U.S. at 484.

117 Greenholtz, 442 U.S. at 11.

118 Id. at $9-10$.

119 Id. at 10 (quoting Sanford H. Kadish, The Advocate and the Expert-Counsel in the Peno-Correctional Process, 45 MinN. L. REV. 803, 813 (1961)).

120 Id.

121 See infra subpart II.B.

122 W. David Ball, Heinous, Atrocious, and Cruel: Apprendi, Indeterminate Sentencing, and the Meaning of Punishment, 109 COLUM. L. REV. 893, 944 (2009).
} 
tion about these standards has not been compiled elsewhere. This subpart presents an overview-relying on state statutes, regulations, and caselaw-of the standards of review of parole board decisions in all fifty states. The Table in the Appendix contains a full description of the states' parole systems, mechanisms for review, and standards for judicial oversight of parole board determinations. ${ }^{123}$

Twenty-seven states exempt parole determinations from judicial review or severely limit the scope of review. ${ }^{124}$ Of that number, eight states appear to entirely prohibit review. ${ }^{125}$ The other nineteen states allow review only for constitutional claims; claims that the parole board's decision violated the governing statute, relevant regulations, or procedural due process requirements; or some combination thereof. ${ }^{126}$

The cases holding that parole board decisions are not at all subject to judicial review reflect the traditional understanding of parole as an act of grace, a privilege, and a decision left entirely to the discretion of the parole board. The Colorado Supreme Court, for example, in addressing whether a prisoner can seek judicial review of a parole denial, explained, "The decision of the Board to grant or deny parole is clearly discretionary since parole is 'a privilege, and no prisoner is entitled to

123 The Robina Institute's Profiles in Parole Release and Revocation provided a helpful starting point. Profiles in Parole Release \& Revocation, ROBINA INST. CRIM. L. \& CRIM. JUST., https://robinainstitute.umn.edu/areas-expertise/paroleprofiles [https://perma.cc/L7EV-2RL5] (last visited Sept. 20, 2020).

124 Those states are Arizona, Arkansas, Colorado, Connecticut, Delaware, Illinois, Indiana, Kentucky, Louisiana, Michigan, Mississippi, Missouri, Montana, Nebraska, Nevada, New Mexico, North Carolina, North Dakota, Ohio, Oklahoma, Pennsylvania, South Dakota, Texas, Utah, Vermont, Virginia, and Wyoming. In Michigan, appeal of a parole board's decision is only allowed by the prosecutor or crime victim, so I have counted this as a state prohibiting the parole applicant from appealing the parole decision. See MicH. Comp. LaWS ANN. § 791.234(11) (West 2020); Morales v. Mich. Parole Bd., 676 N.W.2d 221, 227 (Mich. Ct. App. 2003).

125 Colorado, Illinois, Louisiana, New Mexico, Oklahoma, Pennsylvania, South Dakota, and Wyoming prohibit judicial review of parole board determinations. See Table in Appendix.

126 For example, Arkansas precludes judicial review of an administrative adjudication regarding a prisoner but will review a prisoner's parole decision if the complaint asserts an infringement of constitutional rights. See ARK. CODE ANN. § 25-15-212(a) (West 2020). Delaware courts review parole decisions only to determine whether the board followed the governing statutes and regulations. See Bradley v. Del. Parole Bd., 460 A.2d 532, 534 (Del. 1983). In Indiana, the courts review parole decisions only for procedural due process compliance and to determine whether the board acted within the scope of its own powers. See Murphy v. Ind. Parole Bd., 397 N.E.2d 259, 261 (Ind. 1979). Utah courts will only review the process by which the court reaches its decision but not the decision itself. See Preece v. House, 886 P.2d 508, 512 (Utah 1994). 
it as a matter of right."'127 A Pennsylvania court explained, "[p]arole is nothing more than a possibility, and, when granted, it is nothing more than a favor granted upon a prisoner by the state as a matter of grace and mercy." 128

An Illinois case denying review of a parole denial provides a useful illustration of a court's deference to the parole board's entirely discretionary decision. In Hanrahan $v$. Williams, the Illinois Supreme Court examined Homer Hanrahan's challenge to his parole denial. ${ }^{129}$ Hanrahan was convicted of murder, aggravated kidnapping, aggravated battery, and conspiracy and was sentenced to 50 to 100 years in prison. ${ }^{130}$ After being denied parole, Hanrahan filed a complaint alleging, in part, that the denial "was 'arbitrary and capricious, [and] an abuse of discretion[.]" 131 The court, summarizing Illinois' parole scheme, noted that there were no conditions under which the board must grant parole. ${ }^{132}$ The court invoked the Greenholtz characterization of parole as a "purely subjective appraisal."133 As the court explained, "The Board is free to consider any available relevant information" in making its decision. ${ }^{134}$ For these reasons, the court determined that there were no sufficiently objective criteria on which it could evaluate the parole board's decision and therefore that the legislature must have intended the parole board to have complete discretion. ${ }^{135}$ The court held it could not review the board's decision. ${ }^{136}$

Among the states that allow review only for constitutional claims, procedural due process issues, or statutory or regulatory violations, the decisions reflect a similar understanding of the "almost absolute discretion" of the parole board.137 For example, the Indiana Supreme Court has explained that its courts "cannot act as a 'Super-Parole Board." 138 However, the courts have required "judicial review be available to insure [sic] that the requirements of Due Process have been met and that

127 In re Question Concerning State Judicial Review of Parole Denial Certified by U.S. Court of Appeals for Tenth Circuit, 610 P.2d 1340, 1341 (Colo. 1980) (quoting Silva v. People, 407 P.2d 38, 39 (1965)).

128 Weaver v. Pa. Bd. of Prob. \& Parole, 688 A.2d 766, 770 (Pa. Commw. Ct. 1997).

129673 N.E.2d 251, 252 (Ill. 1996).

130 Id.

131 Id. at 253.

132 Id. at 255.

133 Id. at 256.

134 Id. at 255.

135 Id.

136 Id. at 257.

137 See Holland v. Rizzo, 872 N.E.2d 659, 663 (Ind. Ct. App. 2007).

138 Murphy v. Ind. Parole Bd., 397 N.E.2d 259, 261 (Ind. 1979). 
the Parole Board has acted within the scope of its powers."139 Thus, Indiana courts have entertained claims that parole applicants were not provided with sufficient notice of the reasons for denial or that the board did not consider all relevant information in reaching its decision but will not review the actual decision of the parole board. ${ }^{140}$ The Kentucky Appellate Court has similarly described parole as "a matter of legislative grace" with which the courts will not interfere except to assess whether the board complied with the requirements of due process. ${ }^{141}$ Other states have recognized narrow jurisdiction to review constitutional claims, like race discrimination or retaliation for First Amendment activities, even where review of parole board decisions is otherwise prohibited or narrowly proscribed. ${ }^{142}$

Even in the states that do allow judicial review of the parole board's decision for more than procedural or constitutional compliance, review remains highly deferential to the board. Twenty-two states provide for general review of the parole board's decision under some variation of an arbitrary and capricious or abuse of discretion standard. ${ }^{143}$ In these states, decisions of reviewing courts generally reflect an understanding that parole is a subjective process best left to the discretion

139 Id.

140 See id.; see also Holleman v. State, 27 N.E.3d 344, 346 (Ind. Ct. App. 2015) (noting the limited nature of the court's review).

141 Belcher v. Ky. Parole Bd., 917 S.W.2d 584, 587 (Ky. Ct. App. 1996) (noting that Kentucky's parole statute does not create a liberty interest but acknowledging Belcher's "legitimate interest in a decision rendered in conformity with the established procedures and policies").

142 See, e.g., Mangum v. Miss. Parole Bd., 76 So. 3d 762, 768 (Miss. Ct. App. 2011) (noting that while the parole board has "absolute discretion . . . where constitutional issues are raised, a trial court asserts jurisdiction over those claims"); Cooper v. Mo. Bd. of Prob. \& Parole, 866 S.W.2d 135, 137 (Mo. Ct. App. 1993) (en banc) (addressing prisoner's claim that denial of parole violated the Equal Protection Clause); Woodson v. Ohio Adult Parole Auth., No. 02AP-393, 2002 WL 31722278, *2 (Ohio Ct. App. 2002) ("Because appellant does not allege that his parole was denied for a constitutionally impermissible reason, the OAPA's decision to deny parole is not subject to judicial review . . . .").

143 Those states are Alabama, Alaska, California, Florida, Georgia, Hawaii, Idaho, Iowa, Kansas, Maryland, Massachusetts, Minnesota, New Hampshire, New Jersey, New York, Oregon, Rhode Island, South Carolina, Tennessee, Washington, West Virginia, and Wisconsin. See Table in Appendix. Maine is missing from the total count in this subpart. In that state, which abolished parole in 1976, the courts have recognized a right to petition for post-conviction review of a parole board's decision but the standard of review is unclear. See, e.g., Mahaney v. State, 610 A.2d 738, 741 (Me. 1992) (placing the burden on the petitioner to prove the defect claimed as well as prejudice); Fernald v. Me. State Parole Bd., 447 A.2d 1236, 1239 (Me. 1982) (holding the post-conviction review statute is the "exclusive mode of review of the matters that it covers," which include parole board release decisions, without clarifying the standard of review). 
of the parole board unless the board acts so far outside the bounds of its authority that the courts must step in.

New York provides an example of the common reluctance to interfere with the parole board's discretion. As that state's highest court explained, "To require the Parole Commission to act in accordance with judicial expectations, would substantially undermine the congressional decision to entrust release determinations to the Commission and not the courts." 144 New York courts have interpreted the arbitrary and capricious standard as warranting judicial intervention "only when there is a "showing of irrationality bordering on impropriety." 145 This standard has meant that reviewing courts afford the board a great deal of deference. ${ }^{146}$ For example, in one case, the appellate court concluded that the board had properly denied parole to a "model prisoner" based on the failure of the prisoner, who maintained his innocence, to demonstrate remorse. ${ }^{147}$ The court explained that in many cases New York courts have "reached the same result, on the same basis, when reviewing denials of parole to petitioners whom we recognized as having exemplary records and as being compelling candidates for release." 148 In other instances New York courts have affirmed the Board's decision to "place a greater emphasis on the gravity of [the] crime," so long as the board considered all statutorily required factors. ${ }^{149}$ Courts have also upheld parole board's decisions where the determinations were based on public or political pressure to "get tough" on people who committed violent offenses. ${ }^{150}$ In sum, as long as the parole board demonstrates consideration of statutorily required factors, New York courts are loath to second-guess the board's decision. Many other courts that provide some substantive review of parole board decisions are similarly wary. ${ }^{151}$

144 In re Russo v. N.Y. State Bd. of Parole, 405 N.E.2d 225, 228 (N.Y. 1980).

145 In re Silmon v. Travis, 741 N.E.2d 501, 504 (N.Y. 2000) (quoting In re Russo, 405 N.E.2d at 229).

146 See id. at 504-05.

147 In re Hamilton v. N.Y. State Div. of Parole, 990 N.Y.S.2d 714, 717 (App. Div. 2014).

148 Id. at 718 (listing decisions upholding parole denial despite model institutional records).

149 Id. at 717-18 (alteration in original) (listing decisions upholding denial based on giving greater weight to the seriousness of the crime).

150 See Robles v. Dennison, 745 F. Supp. 2d 244, 278 (W.D.N.Y. 2010), affd, 449 F. App'x 51 (2d Cir. 2011) (citing decisions upholding parole denials resulting from public pressure).

151 See, e.g., Justice v. State Bd. of Pardons \& Paroles, 218 S.E.2d 45, 46 (Ga. 1975) (finding that the parole board members as public officers have absolute discretion unless there is gross abuse); Ybarra v. Dermitt, 657 P.2d 14, 15 (Idaho 
Graham, Miller, and Montgomery provide reason to question this traditional understanding of parole and of the court's role with regard to parole release determinations. With those decisions, the Supreme Court announced that parole is something more than a "discretionary assessment of a multiplicity of imponderables"; ${ }^{152}$ parole is a mechanism that converts an unconstitutional sentence that condemns a juvenile to die in prison into a sentence that complies with Eighth Amendment proportionality principles.

\section{III}

GRAHAM, MILleR, MONTGOMERY, AND THE CHANGing NATURE OF THE PAROLE DETERMINATION

\section{A. The Constitutional Interest in the Parole Board's Decision}

The Court's recent trilogy of juvenile sentencing cases, Graham, Miller, and Montgomery, works to constitutionalize juvenile parole hearings. Graham set the stage with its proclamation that the State must "give defendants like Graham some meaningful opportunity to obtain release based on demonstrated maturity and rehabilitation." 153 The Court explained that its categorical rule prohibiting life without parole for juveniles convicted of nonhomicide offenses gives those individuals "a chance to demonstrate maturity and reform" while life without parole "gives no chance for fulfillment outside prison walls, no chance for reconciliation with society, no hope."154 The Eighth Amendment problem with Mr. Graham's sentence, the Court asserted, is that the "State has denied him any chance to later demonstrate that he is fit to rejoin society based solely on a nonhomicide crime that he committed while he was a child in the eyes of the law." ${ }^{155}$ The Court emphasized the role that parole plays in differentiating between a constitutional sentence and an unconstitutional one: parole provides a

\footnotetext{
1983) (concluding that a "court may not substitute its judgment for that of the Board" and that the scope of review is limited to determining whether there is a "sufficient . . . factual basis" for denial); Kelsey v. State, 283 N.W.2d 892, 894 (Minn. 1979) (stating that traditionally parole was an "act of grace" not subject to judicial review but courts can ensure "legal adequacy of procedures followed" in denying parole); Bussiere v. Cunningham, 571 A.2d 908, 912 (N.H. 1990) (explaining that parole board's decision "must stand if it is supported by a 'modicum of evidence"” (quoting Superintendent v. Hill, 472 U.S. 445, 455 (1985))).

152 Greenholtz v. Inmates of Neb. Penal \& Corr. Complex, 442 U.S. 1, 10 (1979) (quoting Kadish, supra note 119, at 813).

153 Graham v. Florida, 560 U.S. 48, 75 (2010).

154 Id. at 79.

155 Id.
} 
"meaningful opportunity to obtain release," a chance for life outside of prison. ${ }^{156}$ Without such a chance, the Eighth Amendment forbids a sentence of life in prison for a juvenile convicted of a nonhomicide offense. ${ }^{157}$

Graham's categorical bar on life without parole sentences applied only to juveniles convicted of nonhomicide crimes, but Miller made clear that what Graham said about children was not "crime-specific"; rather, the Court's reasoning "implicates any life-without-parole sentence imposed on a juvenile."158 The Court asserted that appropriate circumstances for the imposition of a life without parole sentence "will be uncommon," particularly because of the difficulty in differentiating the individual "whose crime reflects unfortunate yet transient immaturity, and the rare juvenile offender whose crime reflects irreparable corruption." 159

Montgomery completed the circle, explicitly bringing the parole release decision into the realm of the Eighth Amendment. The Court first held that Miller announced a substantive rule that "life without parole [is] an unconstitutional penalty for ... juvenile offenders whose crimes reflect the transient immaturity of youth." 160 The Court explained:

Miller drew a line between children whose crimes reflect transient immaturity and those rare children whose crimes reflect irreparable corruption. The fact that life without parole could be a proportionate sentence for the latter kind of juvenile offender does not mean that all other children imprisoned under a disproportionate sentence have not suffered the deprivation of a substantive right. ${ }^{161}$

The Court made clear that for children whose crimes reflect transient immaturity, a sentence of life without parole is a disproportionate sentence. Serving such a sentence deprives this category of individuals who committed offenses as juveniles - "the vast majority of juvenile offenders"162 - of a substantive, Eighth Amendment right.

The Court reassured states that they could remedy a Miller violation by giving people whose youth was not considered at sentencing an opportunity for parole. ${ }^{163}$ This would ensure,

156 Id. at 75.

157 See id.

158 Miller v. Alabama, 567 U.S. 460, 473, 501 (2012).

159 Id. at 479-80 (quoting Roper v. Simmons, 543 U.S. 551, 573 (2005)).

160 Montgomery v. Louisiana, 136 S. Ct. 718, 734 (2016).

161 Id.

162 Id. at 736.

163 Id. 
the Court asserted, "that juveniles whose crimes reflected only transient immaturity-and who have since matured-will not be forced to serve a disproportionate sentence in violation of the Eighth Amendment." 164 By sanctioning the use of a parole hearing to remedy this violation, the Court placed in the hands of the parole board the task of vindicating an individual's substantive, Eighth Amendment right to a proportionate sentence under Miller and Montgomery. Parole is what transforms a life sentence for someone who was a juvenile at the time of the crime into a constitutional sentence. Without parole, the life sentence is unconstitutional. With it, the sentence passes constitutional muster. ${ }^{165}$

In Jones the Court seemingly backed away from the proportionality language in Miller and Montgomery, repudiating Miller's substantive requirements. ${ }^{166}$ Yet, Jones says very little about parole or what ought to happen after sentencing. The decision is squarely focused on the process required for a front-end sentencing determination. ${ }^{167}$ The crucial point for the Jones Court was that the sentencer have discretion to consider youth. ${ }^{168}$ The Court did not address the substantive determination that a certain category of punishment was unconstitutional for a category of defendants; it addressed "the precise question before [the Court]", i.e. whether Miller requires a finding of permanent incorrigibility before a sentencer may impose life without parole. ${ }^{169}$

164 Id.

165 See also Kristen Bell, A Stone of Hope: Legal and Empirical Analysis of California Juvenile Lifer Parole Decisions, 54 HARV. C.R.-C.L. L. REV. 455, 458-59 (2019) (describing how the "task of providing the constitutionally required 'meaningful opportunity to obtain release' has [ ] been passed into the hands of parole boards"); Laura Cohen, Freedom's Road: Youth, Parole, and the Promise of Miller v. Alabama and Graham v. Florida, 35 CARDOZO L. REV. 1031, 1058-59 (2014) (critically evaluating the assumption that parole eligibility in and of itself renders an invalid sentence constitutional); Matthew Drecun, Note, Cruel and Unusual Parole, 95 TEX. L. REV. 707, 728-29 (2017) (analyzing cases interpreting Graham and finding that Graham creates new standards for parole boards that, if not met, can turn a constitutional life with parole sentence into an unconstitutional sentence that is the functional equivalent of life without parole); Sarah French Russell, Review for Release: Juvenile Offenders, State Parole Practices, and the Eighth Amendment, 89 IND. L.J. 373, 414 (2014) (explaining that "simply making juvenile offenders eligible for parole under existing practices will not guarantee compliance with Eighth Amendment requirements").

166 See, e.g., Jones, 141 S. Ct. at 1311, 1314 (explaining that Miller requires "only that the sentencer follow a certain process" (internal quotation marks omitted)); Id. at 1317 (reducing Miller to a requirement for a "discretionary sentencing procedure").

167 Id.

168 Id. at 1313.

169 Id. at 1322. 
Jones has little if anything to say about a back-end determination of how long a person ought to serve in prison or what might be required in a parole proceeding. Nor about what strictures might bind administrative, as opposed to judicial, decision-makers. Indeed, it leaves unanswered the question whether the constitution demands something different when an administrative body decides, years into a sentence, how long someone who was a child at the time of the crime ought to spend in prison. The Jones Court's proclamation that a sentencer given discretion will reach the right decision ${ }^{170}$ leaves unanswered what Miller and Montgomery mean for parole determinations. The question remains whether parole eligibility alone is sufficient to transform an unconstitutional sentence into a constitutional one or whether parole for people who were children at the time of the crime must do something more.

\section{B. A Hope of Release}

Montgomery's pronouncements-that parole consideration "ensures that juveniles whose crimes reflected only transient immaturity ... . will not be forced to serve a disproportionate sentence," and that "[t]he opportunity for release will be afforded to those who demonstrate . . . [they] are capable of change," 171 -reflect an understanding that juvenile parole applicants have an Eighth Amendment interest in the outcome of their hearing. Without such an interpretation, these statements lose meaning.

Nevertheless, the Court's words could be read to mean simply that someone who was under age eighteen at the time of the crime has an interest in the hope of release. Under such a reading, the individual has an interest in being afforded a parole hearing but not in the board's ultimate decision. This interpretation of the constitutional interest as one in the possibility of parole comes from language in Montgomery, and especially in Graham, describing the need to provide a chance at release. The Montgomery Court stated that if an individual can show that their crime did not reflect incorrigibility, then "hope for some years of life outside prison walls must be restored."172 The Graham Court meanwhile specified that the State was "not required to guarantee eventual freedom" and that "[t]he Eighth Amendment does not foreclose the possibility that persons convicted of nonhomicide crimes committed before adulthood will

$170 \quad$ Id. at 1318.

171 Montgomery, 136 S. Ct. at 736.

172 Id. at 737 (emphasis added). 
remain behind bars for life."173 In other words, the Court seemingly sanctioned the idea that some people will never be granted parole. ${ }^{174}$ Indeed, the Massachusetts Supreme Court picked up on this theme in its Diatchenko decision, emphasizing that the constitutional right of the juvenile parole applicant "is not a guarantee of eventual release, but an entitlement to a meaningful opportunity for such release based on demonstrated maturity and rehabilitation." 175

Yet, to conclude from these statements that juvenile parole applicants are entitled only to hope, to no more than a chance at release, would belie the Court's conclusion about people who commit crimes as children: that the vast majority of them should not be forced to die in prison. ${ }^{176}$ An interest only in the possibility of parole would mean that someone who demonstrates that their crime was the result of transient immaturity and that they have subsequently matured could still be forced to serve a lifetime in prison. They could be given parole hearings, fulfilling the requirement for an opportunity to be released, but could be denied release and forced to serve life in prison, regardless of evidence of rehabilitation. ${ }^{177}$ Reading the Court's decisions to require opportunities for parole with no guarantee of actual release if the individual demonstrates maturity and reform would ignore Graham's requirement of a "meaningful opportunity to obtain release based on demonstrated maturity and rehabilitation." 178 It would render empty "Miller's conclusion that the sentence of life without parole is disproportionate for the vast majority of juvenile offenders." 179 And it would flout Montgomery's promise that those individuals will not be forced to serve a disproportionate sentence. ${ }^{180}$

Reducing these cases to a hope of release would also ignore the Court's underlying analysis. Graham does not require a guarantee of release from prison. However, the Court reasoned

173 Graham v. Florida, 560 U.S. 48, 75 (2010).

174 As perhaps did the dissent in Jones, reasoning that Mr. Jones sought only "the possibility of parole" and that he "recognizes that the parole board may ultimately decide he must spend his entire life behind bars." Jones, $141 \mathrm{~S}$. Ct. at 1340 (Sotomayor, J., dissenting).

175 Diatchenko v. Dist. Att'y for Suffolk Dist., 27 N.E.3d 349, 365 (Mass. 2015) (emphasis added).

176 See Montgomery, 136 S. Ct. at 736.

177 See Cohen, supra note 165, at 1062 ("The oft-illusory hope for release, then, does not in and of itself ease the experiential severity of a life prison term. Something more than 'hope' is necessary to render an otherwise disproportionate sentence constitutional.").

178 Graham, 560 U.S. at 75 (emphasis added).

179 Montgomery, 136 S. Ct. at 736.

180 Id. 
that a guarantee was not required because there might be some small minority of people for whom life in prison is a proportionate punishment. As the Court explained, "[t]hose who commit truly horrifying crimes as juveniles may turn out to be irredeemable, and thus deserving of incarceration for the duration of their lives." 181 In other words, states need not guarantee release to everyone because some very small number of juveniles might turn out to be irredeemable. Yet, the Court's statement also assumes that those who are not irredeemable are not deserving of incarceration for the rest of their lives. For this reason, "a lifetime in prison is a disproportionate sentence for all but the rarest of children . . . ."182

As the Court has repeatedly echoed from Roper to Montgomery, it is "the rare juvenile offender whose crime reflects irreparable corruption."183 In Montgomery the Court warned, "Miller's conclusion that the sentence of life without parole is disproportionate for the vast majority of juvenile offenders raises a grave risk that many are being held in violation of the Constitution." 184 If the constitutional violation is that the vast majority of people who committed crimes as children are held in prison in violation of the Eighth Amendment, a mere hope of parole does not remedy that violation. Only release from prison upon demonstration of subsequent maturity and reform would satisfy the Court's promise that parole can cure the unconstitutionality of a life sentence. Thus, for people who committed crimes as children, the substance of the parole board's decision-and not only the opportunity for release-assumes constitutional significance.

\section{How the Eighth Amendment Interest in Parole Changes the Nature of the Hearing}

In the case of juvenile parole hearings, the parole board is making a constitutional determination-a determination that is meant to bring the sentence into compliance with the Eighth Amendment. Without parole, a sentence of life in prison is invalid for someone who was a child at the time of the crime. With parole, the sentence becomes valid. Parole is performing a constitutionalizing function that transforms the board's deci-

\footnotetext{
181 Graham, 560 U.S. at 75.

182 Montgomery, 136 S. Ct. at 726.

183 Roper v. Simmons, 543 U.S. 551, 573 (2005); Montgomery, 136 S. Ct. at 726, 734; Miller v. Alabama, 567 U.S. 460, 479-80 (2012); Graham, 560 U.S. at 68.

184 Montgomery, 136 S. Ct. at 736 (emphasis added).
} 
sion from a discretionary act of grace into a constitutionally required consideration of maturity and rehabilitation.

In the context of juvenile parole hearings, the parole decision is no longer a purely subjective appraisal. Rather, there is a "set of facts which, if shown, mandate a decision favorable to the individual." 185 Demonstrated maturity and rehabilitation must allow a prisoner to gain release from prison. ${ }^{186}$ Juvenile parole applicants "whose crimes reflected only transient immaturity" and who show subsequent maturity cannot "be forced to serve a disproportionate sentence." 187 A lifetime in prison is disproportionate "for all but the rarest of children, those whose crimes reflect 'irreparable corruption." 188 If a juvenile parole applicant demonstrates that their crime was not the result of irreparable corruption, that it was an indication of transient immaturity, and that they have subsequently matured and rehabilitated, they cannot be denied parole and forced to spend the rest of their life in prison.

The focus of the juvenile parole hearing will, then, be on rehabilitation rather than on the nature of the underlying crime, as is typical in most modern parole reviews. A parole board's determination often turns on an assessment of the seriousness of the offense and the parole applicant's ability to live in the community without violating the law. ${ }^{189}$ While the latter consideration can map onto an understanding of rehabilitation and reform, the former is a static understanding of the nature of the crime that does not account for children's heightened capacity for rehabilitation. ${ }^{190}$ Focus on the offense emphasizes retribution over rehabilitation. But Graham cautioned:

Society is entitled to impose severe sanctions . . . to express its condemnation of the crime and to seek restoration of the moral imbalance caused by the offense. But "[t]he heart of

185 Greenholtz v. Inmates of Neb. Penal \& Corr. Complex, 442 U.S. 1, 10 (1979).

186 See Graham, 560 U.S. at 75.

187 Montgomery, 136 S. Ct. at 736.

188 Id. at 726.

189 See Brown v. Precythe, No. 2:17-cv-04082-NKL, 2018 WL 4956519, at *9 (W.D. Mo. Oct. 12, 2018) ("All parole decisions must be attributed to one of two concededly 'barebones, boilerplate' reasons: the seriousness of the offense or inability to live and remain at liberty without aga in [sic] violating the law."); Hawkins v. N.Y. State Dep’t of Corr. \& Cmty. Supervision, 30 N.Y.S.3d 397, 398 (App. Div. 2016) (denying parole because release "would so deprecate the seriousness of [his] offense as to undermine respect for the law").

190 See Sarah Russell, The Role of the Crime at Juvenile Parole Hearings: A Response to Beth Caldwell's Creating Meaningful Opportunities for Release, 41 HARBINGER 227, 231 (2016) ("[T]he severity of the crime should carry no weight in a parole board's release decision in juvenile cases."). 
the retribution rationale is that a criminal sentence must be directly related to the personal culpability of the criminal offender." And as Roper observed, "[w]hether viewed as an attempt to express the community's moral outrage or as an attempt to right the balance for the wrong to the victim, the case for retribution is not as strong with a minor as with an adult."191

Roper recognized the risk that the nature of the crime would overwhelm youth-related mitigation. The Court explained, "[a]n unacceptable likelihood exists that the brutality or coldblooded nature of any particular crime would overpower mitigating arguments based on youth as a matter of course, even where the juvenile offender's objective immaturity, vulnerability, and lack of true depravity should require a sentence less severe than death." 192 Although Roper addressed the capital context, Graham explicitly correlated juvenile life-without-parole sentences to the death penalty. ${ }^{193}$ Roper's concern that a brutal crime might overwhelm consideration of youth and redemptive capacity is just as apt in the context of life without parole. Indeed, Miller's "central intuition" was "that children who commit even heinous crimes are capable of change." 194 A parole board decision, then, that allows the seriousness of the crime to trump considerations of change and rehabilitation does not comport with the Supreme Court's assessment that the nature of the crime cannot overpower a youth's lessened culpability and greater capacity for change.

Instead, the juvenile parole process is intended to prioritize rehabilitation. From its earliest iterations in this country, parole has been understood as "a regular part of the rehabilitative process." 195 In Graham, the Court asserted that rehabilitation is "a penological goal that forms the basis of parole systems." 196 This rehabilitative focus becomes central to the juvenile parole hearing. Ignoring rehabilitation and "denying the defendant the right to reenter the community" is "an irrevocable judgment about that person's value and place in society" that "is not

191 Graham, 560 U.S. at 71 (citation omitted).

192 Roper v. Simmons, 543 U.S. 551, 573 (2005).

193 Graham, 560 U.S. at 69.

194 Montgomery v. Louisiana, 136 S. Ct. 718, 724 (2016).

195 Solem v. Helm, 463 U.S. 277, 300 (1983); see also Mistretta v. United States, 488 U.S. 361, 363 (1989) ("Both indeterminate sentencing and parole were based on concepts of the offender's possible, indeed probable, rehabilitation, a view that it was realistic to attempt to rehabilitate the inmate and thereby to minimize the risk that he would resume criminal activity upon his return to society.").

196 Graham, 560 U.S. at 73. 
appropriate in light of a juvenile['s] . . . capacity for change and limited moral culpability." 197 The board cannot deny release in its discretion if it finds the crime was the result of transient immaturity and that the parole applicant has subsequently matured.

Courts reviewing parole hearings post-Graham, Miller, and Montgomery have recognized the constitutional nature of juvenile parole determinations. These decisions reveal an understanding that parole hearings for people who were children at the time of their crimes require consideration different from traditional parole hearings for incarcerated adults.

In Greiman v. Hodges, the U.S. District Court for the Southern District of Iowa analyzed, in the context of a prisoner's § 1983 claim, whether a parole hearing provided a "meaningful opportunity for relief" under Graham. ${ }^{198}$ The Iowa legislature had created parole eligibility after twenty-five years in prison for people incarcerated for a Class A felony that occurred when they were younger than eighteen years old. ${ }^{199}$ The plaintiff, who was originally sentenced to life without parole, was resentenced under the new law to life with the possibility of parole. ${ }^{200}$ The parole board twice denied him parole based on the seriousness of the crime, and the Plaintiff brought a $\S 1983$ action alleging that the board failed to provide a meaningful opportunity for parole and to consider his youth, demonstrated maturity, and rehabilitation. ${ }^{201}$ The parole board (IBOP) filed a motion to dismiss, arguing that the plaintiff was claiming a right to an enhanced, "super" parole review beyond the normal parole process, and that Graham is limited to sentencing rather than parole considerations. ${ }^{202}$ The court denied the IBOP's motion to dismiss, explaining that an opportunity to prove that the plaintiff should be released before the expiration of his life sentence could only reasonably exist during parole review. ${ }^{203}$ As the court elaborated:

[T] he ultimate length of Plaintiff's prison sentence will be determined by the IBOP, because it alone has the authority to grant Plaintiff release. . . . Thus . . . the responsibility for

197 Id. at 74. See Russell, supra note 190, at 231 (arguing that the focus of juvenile parole hearings should be on whether the parole applicant has demonstrated maturity and rehabilitation).

19879 F. Supp. 3d 933, 935-36 (S.D. Iowa 2015).

199 Id. at 935.

200 Id. at 935-36.

201 Id. at 936.

202 Id. at 942.

203 Id. at 943. 
ensuring that Plaintiff receives his constitutionally mandated 'meaningful opportunity to obtain release based on demonstrated maturity and rehabilitation' lies squarely with [the parole board] and the other State-actor Defendants. ${ }^{204}$

In rejecting the board's argument, the court implicitly acknowledged that juvenile parole hearings do entail a sort of "super" parole hearing that will differ from a normal parole proceeding.

Similarly, in Diatchenko v. District Attorney for Suffolk District, the Massachusetts Supreme Court reasoned that because juvenile parole hearings have a constitutional dimension, they must be accompanied by certain procedural protections. ${ }^{205}$ In that case, juvenile parole applicants argued that, in order for parole review to be meaningful, they must have access to counsel, expert witnesses, and an opportunity for judicial review of the parole board's decision. ${ }^{206}$ The court first determined that "in light of the fact that the offender's opportunity for release is critical to the constitutionality of the sentence," juvenile parole applicants must have access to counsel, as well as to funds for expert witnesses. ${ }^{207}$ The court then held that juvenile parole hearings must be subject to judicial review. The court explained, "[T]he parole hearing acquires a constitutional dimension for a juvenile homicide offender because the availability of a meaningful opportunity for release on parole is what makes the juvenile's mandatory life sentence constitutionally proportionate." 208 Therefore, the court must be allowed to ensure that the "right of a juvenile homicide offender to a constitutionally proportionate sentence is not violated."209

Greiman and Diatchenko reflect an analysis that the juvenile parole hearing serves a function different than a typical adult parole hearing: the juvenile hearing provides the constitutionally required opportunity to demonstrate that the juvenile parole applicant should not be imprisoned for the rest of their life. ${ }^{210}$ This constitutional function mandates standards to ensure the parole applicants' rights are vindicated.

\section{Id.}

20527 N.E.3d 349, 369 (Mass. 2015).

206 Id. at 353.

207 Id. at 361.

208 Id. at 365.

209 Id.

210 See also Brown v. Precythe, No. 2:17-cv-04082-NKL, 2017 WL 4980872, at *13 (W.D. Mo. Oct. 31, 2017) (denying motion to dismiss and granting leave to amend). In that case, the U.S. District Court for the Western District of Missouri considered whether Missouri's parole procedures and practices for individuals who were juveniles at the time of the offense violated the state and federal constitutions. Under the new law, the board was required to consider, among other 


\section{Proposed Standard for Parole Board Review of Juvenile Parole Hearings: Presumption of Release}

Based on the Court's reasoning in Graham, Miller, and Montgomery, the parole board ought to presume maturity and rehabilitation and, therefore, release for juvenile parole applicants. $^{211}$ Only if the evidence establishes by clear and convincing evidence that the crime was not the result of transient immaturity and that the parole applicant has not matured and rehabilitated should the board deny release.

Such a standard comports with the understanding that for the "vast majority" of people who committed crimes as children, the crime will be the result of transient immaturity, and life in prison would be a disproportionate punishment. ${ }^{212}$ Children, the Court has determined, but for a few "incorrigible[s]," have a unique "capacity for change." 213 In other words, a juvenile parole applicant whose crime is not the result of transient immaturity and who has not subsequently matured and reformed is the exception, not the rule. Given this understanding, it does not make sense to task juvenile parole applicants with proving that they are not the exception to the rule. The board

factors, the applicant's rehabilitation, growth and maturity, and risk to society. Id. at *3. The plaintiffs were denied parole at their initial hearings and scheduled for a five-year setback. Id. at*1. Plaintiffs alleged that the new parole legislation failed to provide the constitutionally required meaningful opportunity for release. Id. at *6. The court rejected defendant's motion to dismiss, relying on the alleged facts that, inter alia, the board granted parole in only two of twenty hearingsmost denials cite only the seriousness of the offense, while plaintiffs' "prison records may show maturity and rehabilitation." Id. at *10. The court thus acknowledged that a meaningful opportunity for release may require more than a statutory requirement that the board consider growth and maturity.

211 Some scholars have suggested that presumptions, with certain limitations, should apply to juvenile parole hearings. See Sarah Sloan, Note, Why Parole Eligibility Isn't Enough: What Roper, Graham, and Miller Mean for Juvenile Offenders and Parole, 47 COLUM. HUM. RTS. L. REV. 243, 275-76 (2015) (arguing for a presumption of release for juvenile parole applicants with exceptions for "objective, easily documented, and easily verified" circumstances, which would be statutorily enumerated, and could include a "major disciplinary infraction in the past year," "recent threats," or failure to express remorse). See also Beth Caldwell, Creating Meaningful Opportunities for Release: Graham, Miller and California's Youth Offender Parole Hearings, 40 N.Y.U. REv. L. \& Soc. CHANGE 245, 297 (2016) (proposing that a presumption against current dangerousness could apply if a parole applicant demonstrates their crime was the result of transient immaturity or outside influence or that they have matured since the time of the crime); Cohen, supra note 165, at 1087 (recommending a presumption of release on parole upon completion of a minimum term and "if current dangerousness is not established").

212 Montgomery v. Louisiana, 136 S. Ct. 718, 734 (2016).

213 Graham v. Florida, 560 U.S. 48, 77 (2010). 
should give credit to the expectation, grounded in science 214 and in the law, that the vast majority of people who were children at the time of the crime will rehabilitate.

A presumption of release would both work to ensure that juvenile parole hearings meet the constitutional task set for them, and to create a clear, workable standard for the parole board to apply. The presumption would also give life to Montgomery's promise that parole will ensure that those who have matured "will not be forced to serve a disproportionate sentence," 215 in part by preventing blanket or knee-jerk denials, and by setting a clear expectation that juvenile parole applicants should be granted parole in most circumstances. Such an expectation is necessary to counteract boards' reluctance to grant release, particularly to individuals serving long sentences for serious crimes. ${ }^{216}$ In addition, a presumption of release gives the parole board a clear baseline from which to assess the case before them, rather than requiring the board to weigh a laundry list of factors in order to determine suitability for release.

A few jurisdictions provide examples of a presumption of release in practice. In 2014 the Washington State legislature enacted changes to the state's parole statutes, allowing individuals convicted of crimes committed before age eighteen to petition for early release after serving twenty years in prison. ${ }^{217}$ The legislation provides that the parole board "shall order the person released . . . unless the board determines by a preponderance of the evidence that, despite such conditions, it is more likely than not that the person will commit new criminal law violations if released." 218 As the Washington Appellate Court has explained, the legislation "expressly contemplates that the offender will not serve more than 20 years of their sentence

214 See, e.g., Terrie E. Moffitt, Adolescent-Limited and Life-Course-Persistent Antisocial Behavior: A Developmental Taxonomy, 100 PSYCHOL. REV. 674, 685-86, 690 (1993) (finding that the majority of teenagers who engage in delinquent activities engage in this antisocial behavior only temporarily during adolescence); Laurence Steinberg \& Elizabeth S. Scott, Less Guilty by Reason of Adolescence: Developmental Immaturity, Diminished Responsibility, and the Juvenile Death Penalty, 58 AM. PSYCHOLOGIST 1009, 1014-15 (2003) (summarizing science that demonstrates that juveniles have a deficient capacity for decision-making, heightened vulnerability to coercion, and less-developed characters).

215 Montgomery, 136 S. Ct. at 736.

216 See Sharon Dolovich, Creating the Permanent Prisoner, in LiFE WITHOUT PAROle: AMERICA's NEW DEATH PENALTY? 96, 110-11 (Charles J. Ogletree, Jr. \& Austin Sarat eds., 2012).

217 S.B. 5064 § 10, 63rd Leg., 2014 Reg. Sess. (Wash. 2014).

218 Id. 
unless they are likely to reoffend." 219 Colorado has also created a presumption in favor of parole for individuals who complete a recently enacted Department of Corrections program for anyone convicted of a felony committed as a juvenile. ${ }^{220}$ The program provides participants with "more independence in daily life," and requires employment and programming to "support the offender's successful reintegration."221 Anyone who completes this program is eligible for early parole and, if they have served at least twenty-five or thirty years in prison (depending on the crime), "it is presumed" that they have met the requirements for a grant of parole. The presumed requirements are: 1) that there are "extraordinary mitigating circumstances," and 2) that release "is compatible with the safety and welfare of society." 222

California's parole scheme operates under a presumption of release for parole applicants regardless of their age at the time of the crime. The governing statute provides that the board "shall grant parole to an inmate unless it determines that the gravity of the current convicted offense or offenses, or the timing and gravity of current or past convicted offense or offenses, is such that consideration of the public safety requires a more lengthy period of incarceration." 223 As the California Supreme Court has explained, "parole applicants in this state have an expectation that they will be granted parole unless the Board finds, in the exercise of its discretion, that they are unsuitable." 224 In other words, release on parole is "the rule, rather than the exception." 225 The juvenile parole statute

219 In re Brashear, 430 P.3d 710, 715 (Wash. Ct. App. 2018), review granted sub nom., 448 P.3d 764 (Wash. 2019) (emphasis omitted).

220 See Colo. REV. STAT. ANN. § 17-34-102(8) (2020).

221 Id. § 17-34-102(2). This program appears to recognize what some advocates have urged: a meaningful opportunity for release must entail access to meaningful opportunities to rehabilitate while in prison. See, e.g., Caldwell, supra note 211, at 286-91 (2016) (arguing that access to rehabilitative programs in prison is "fundamental" to providing a meaningful opportunity for release); Sally Terry Green, Realistic Opportunity for Release Equals Rehabilitation: How the States Must Provide Meaningful Opportunity for Release, 16 BERKELEY J. CRIM. L. 1, 37 (2011) (arguing that the "meaningfulness" of the opportunity for release for juveniles serving life in prison "is directly related to participation in whatever rehabilitative programs are available”); Marsha L. Levick \& Robert G. Schwartz, Practical Implications of Miller and Jackson: Obtaining Relief in Court and Before the Parole Board, 31 LAW \& INEQ. 369, 393-401 (2013) (arguing that programing in prison must be both available and meaningful for juveniles who are now eligible for parole).

222 § 17-34-102(7)-(8).

223 CAL. PENAL CODE § 3041(b)(1) (West 2020).

224 In re Rosenkrantz, 59 P.3d 174, 203 (Cal. 2002).

225 In re Hunter, 141 Cal. Rptr. 3d 350, 361 (Ct. App. 2012). 
incorporates this presumption of parole, and requires consideration of "the diminished culpability of youth," "the hallmark features of youth," and "any subsequent growth and increased maturity" in order to provide for "a meaningful opportunity to obtain release." 226 Recent Board of Parole Hearings regulations more explicitly condition denial upon a finding that the parole applicant's current risk to public safety outweighs "the youth offender factors." 227

These states provide examples of a presumption of release for juvenile parole applicants, but two caveats bear emphasizing. First, given the constitutional right at stake, the evidence required to rebut the presumption ought to be held to a higher standard than some evidence or a preponderance of the evidence. Second, the evidence ought to be current and actually reflective of the parole applicant's lack of rehabilitation and current danger to the public if released.

Because the parole applicant's constitutional right to a proportionate sentence is at stake, there should be a fairly high threshold for the evidence that would overcome the presumption of release. The Supreme Court has explained, "The function of a standard of proof . . . is to instruct the factfinder concerning the degree of confidence our society thinks he should have in the correctness of factual conclusions for a particular type of adjudication.'" 228 In this instance, given that the parole board's determination that the applicant has not rehabilitated would mean precluding someone imprisoned as a child from reentering society, the board ought to have a firm conviction in the accuracy of such a determination. Further, the standard of proof "serves to allocate the risk of error between the litigants and to indicate the relative importance attached to the ultimate decision." 229 Here, the risk to the State is releasing someone who might not be rehabilitated and who might commit another offense. The risk to the individual is being forced to serve a lifetime in prison and to suffer a disproportionate sentence. A clear and convincing standard would reflect the gravity of the interests at stake and reduce the risk that an individual's Eighth Amendment rights would be vio-

226 CAL. PENAL CODE § 3051(d)-(f) (West 2020).

227 CAL. CODE REGS. tit. $15 \S 2445$ (d) (2020).

228 Addington v. Texas, 441 U.S. 418,427 (1979) (addressing the standard of proof required in civil commitment hearings and determining that something more than a preponderance of the evidence was necessary).

229 Id. at 423. 
lated. ${ }^{230}$ It would not set an unreasonably high barrier to finding a lack of rehabilitation, but would ensure that the presumption of rehabilitation and release, based in science and in the Court's pronouncements, would not be overcome lightly.

Second, the requirement to overcome the presumption of release should be focused on current evidence of the parole applicant's lack of rehabilitation. Broad assessment of potential risk to public safety-often the concern of parole boards ${ }^{231}$-ought not be the standard. Such emphasis hazards being disconnected from current rehabilitation and actual danger because of reliance on the underlying offense and other static factors. ${ }^{232}$ For example, California's general parole statute allows the board to consider "the gravity of the current convicted offense or offenses" in assessing whether the presumption of parole should be overcome. ${ }^{233}$ Yet, as discussed in section III.C., supra, a parole decision based on a crime committed decades earlier does not give credit to children's capacity for change. And the underlying offense neither speaks to whether the person has since rehabilitated, nor whether they pose any current danger. As Professor Sarah Russell has noted, the sentencing judge has already accounted for the nature of the crime, and by the time of the parole hearing, "the sentence has served its retributive purpose, and the relevant question should be whether the individual has demonstrated rehabilitation and can be safely released into society."234 Nor do disciplinary violations from the individual's early years in prison reflect their current rehabilitation. ${ }^{235}$

230 This is the standard required by some states in parole or probation revocation hearings. See MinN. R. 27.04 (2020) (providing that revocation hearing is held to determine whether "clear and convincing evidence of a probation violation exists and whether probation should be revoked"); NEB. REV. STAT. § 29-2267 (2016) (providing that violation of probation must be established by clear and convincing evidence); N.J. STAT. ANN. § 30:4-123.63(d) (West 2020) (providing that parole board may revoke parole if "there is clear and convincing evidence that a parolee has violated the conditions of his parole").

231 See, e.g., CAL. PENAL CODE $\S 3041(\mathrm{~b})(1)$ (West 2020) (providing for a presumption of release unless public safety requires continued incarceration); 61 PA. CONS. STAT. § 6102 (2021) (requiring that the parole board shall "first and foremost seek to protect the safety of the public"); WASH. REV. CODE. $§ 9.95 .009$ (2011) (emphasizing that public safety considerations should be given highest priority). 232 See, e.g., CAL. PENAL CODE § 3041(b)(1) (West 2020) (providing that consideration of public safety is judged based on "gravity of the current convicted offense or offenses").

233 Id.

234 Russell, supra note 190, at 231.

235 See Attapol Kuanliang, Jon R. Sorensen \& Mark D. Cunningham, Juvenile Inmates in an Adult Prison System: Rates of Disciplinary Misconduct and Violence, 35 CRIM. JUST. \& BEHAV. 1186, 1196-97 (2008) (reporting that in a study of 
Further, assessment of potential risk based on static and unchangeable factors is problematic in its potentially racially disparate impact. ${ }^{236}$

As an example of a standard focused-at least in policyon the parole applicant's current rehabilitation, California's juvenile parole regulations require the board to grant parole unless the hearing panel determines that youth-related mitigation is "outweighed by relevant and reliable evidence that the youth offender remains a current, unreasonable risk to public safety."237 This focus on a "current, unreasonable risk" asks the board to examine not decades old information, and not any suggestion of potential risk, but rather reliable evidence of current danger.

A reliance on rehabilitation in juvenile parole determinations may be subject to the critique that it is too vague a benchmark to practically apply. As the Graham Court has noted, "The concept of rehabilitation is imprecise." ${ }^{338}$ Yet, a presumption of release would task the board with determining if someone has not rehabilitated, and it is a more practical standard to assess what is not rehabilitation than what is. For example, while an unremarkable institutional record with evidence of neither good nor bad behavior might pose a difficulty in determining whether it demonstrates reform, such a record would be uncomplicated with a presumption of release in place. Meanwhile, evidence that an individual was recently convicted for another criminal offense while in prison, or that they received recent disciplinary reports for serious misbehavior could support a determination that someone has not, in fact, reformed.

A robust standard for the parole board that sets a clear expectation that the board should presume release would work

prisoners in a Florida institution, compared to older prisoners, juveniles were far more likely to receive disciplinary violations, including for violent behavior); Margaret E. Leigey \& Jessica P. Hodge, And Then They Behaved: Examining the Institutional Misconduct of Adult Inmates Who Were Incarcerated as Juveniles, 93 PRISON J. 272, 285-86 (2013) (noting that, over time, individuals convicted as juveniles become indistinguishable in terms of misconduct from individuals convicted as adults).

236 See Cecilia Klingele, The Promises and Perils of Evidence-Based Corrections, 91 NOTRE DAME L. REV. 537, 561 (2015) (“Hunches about 'risk' are often rooted in misinformation and subconscious biases about race, class, and culture that often bear only passing resemblance to actual dangerousness."); Bernard E. Harcourt, Risk as a Proxy for Race: The Dangers of Risk Assessment, 27 FED. SENT'G. REP. 237, 237 (2015) (risk assessment tools exacerbate racial disparities in criminal justice system).

237 CAL. CODE. REGS. tit. $15 \S 2445$ (d) (2020).

238 Graham v. Florida, 560 U.S. 48, 73 (2010). 
to ensure juvenile parole hearings meet their constitutional task. Alone, however, it would not fulfill the Court's promise that those who demonstrate maturity and reform will not be forced to spend their lives in prison. Parole boards are, as described in section IV.A., infra, administrative bodies often comprised of politically well-connected individuals with little criminal justice experience. They are risk averse, and often loath to grant parole, particularly in cases involving serious crimes and long sentences. ${ }^{239}$ In some states parole grant rates are as low as 0.5 percent, even for people who were under age eighteen at the time of the offense, and grant rates are often lower for serious offenses. ${ }^{240}$ Moreover, given the Court's pronouncement that it is the rare, irreparably corrupt juvenile who should be forced to spend their life in prison, ${ }^{241}$ any parole denials should be carefully scrutinized. A meaningful opportunity for release must, therefore, include judicial review of the parole board's decisions.

\section{IV}

\section{Judicial ReVIEW of JuVEnile PaROle Determinations}

\section{A. The Case for Judicial Review}

Juvenile parole hearings can serve as a filter that relieves states of the task of resentencing every individual subject to life without parole for an offense that occurred when they were children. As Montgomery promised, states need not resentence every person who has been sent to prison for life for a juvenile offense. ${ }^{242}$ Parole boards, rather than courts, can take on the heavy task of assessing the rehabilitation of juvenile parole applicants. The boards may in many cases affirm Montgomery's promise and grant parole to those who demonstrate maturity and rehabilitation. And a presumption of release would help ensure that individuals who demonstrate their crime was the result of transient immaturity are not subject to spend the rest of their lives in prison. But judicial review should be available to assure that, if an individual's Eighth Amendment right to a proportionate sentence is not vindicated, the violation is

239 See Dolovich supra note 216, at 111-12.

240 Sarah Mehta, AClU, False Hope: How Parole Systems Fail Youth Serving EXTREME SENTENCES 45-46, (2016) (citing, inter alia, Florida parole grant rates in FY 2013-2014; Missouri 2015 grant rate of $81 \%$ generally compared to $29 \%$ for individuals serving a juvenile life sentence; Maryland general grant rate of $40 \%$ while no juvenile lifers have been granted parole in the past twenty years).

241 See Montgomery v. Louisiana, 136 S. Ct. 718, 734, 736-37 (2016).

242 Id. at 736. 
remedied. The courts, rather than an administrative agency, should be the ultimate forum for determining whether there has been a violation of a constitutional right.

Parole board members are typically political appointees without legal experience. In most states, parole board members are appointed by the governor. ${ }^{243}$ For this reason, board composition is shaped by the political process, and board members tend to be politically well-connected. ${ }^{244}$ A minority of states require that board members have experience in the criminal justice system or a related field. ${ }^{245}$ Nineteen states have no baseline requirements for parole board membership. ${ }^{246} \mathrm{~Pa}-$ role systems responding to a recent Robina Institute Survey counted $10 \%$ of members with a high school diploma as their highest educational achievement, $38 \%$ of members with a bachelor's degree, and $21 \%$ with a juris doctorate. ${ }^{247}$ Information about parole board chairs in particular reflects that almost $20 \%$ have never worked in a criminal justice related field, almost half had been police, probation, or corrections officers, about $20 \%$ were lawyers, and about $3 \%$ had been judges. ${ }^{248}$ In short, parole board members are extremely unlikely to have a background in constitutional law, are almost certainly unfamiliar with making constitutional determinations, and are not likely to have experience with the criminal system.

The Court has recognized a strong presumption of judicial review of agency actions. ${ }^{249}$ In the federal context, "judicial review of a final agency action . . . will not be cut off unless there is persuasive reason to believe that such was the purpose of Congress," 250 or unless the action is committed by law to the discretion of the agency. ${ }^{251}$ As described above, Graham,

243 EBONy L. RUHLAND, EdWARD E. RHINE, JASON P. ROBEy \& KELly LyN MitCHELl, RoBina INST. OF CRIM. L. \& CRIM. J., THE CONTINUING LEVERAGE OF RELEASING AUTHORITIES: FindingS FROM A NATIONAL SURVEY 18 (2017), https://robinainstitute.umn.edu/sites/robinainstitute.umn.edu/files/

final_national_parole_survey_2017.pdf [https://perma.cc/BM7N-MAEE] [hereinafter ROBINA RELEASING AUTHORITIES SURVEY].

244 See Cohen, supra note 165, at 1072.

245 ROBINA RELEASING AUTHORITIES SURVEY, supra note 243, at 17.

246 Id.

247 Id. at 20.

248 Jason P. Robey \& EdWARd E. Rhine, Robina InST. OF CRIM. L. \& CRim. J., PAROLE BOARD MEMBERS: STATUTORY REgUIREMENTS, EDUCATIONAL ACHIEVEMENTS, AND INSTITUTIONAL STRUCTURE 3-4 (2017), https://robinainstitute.umn.edu/newsviews / parole-board-members-statutory-requirements-educational-achievements-and-institutional [https://perma.cc/HX3F-95AQ].

249 Abbott Labs v. Gardner, 387 U.S. 136, 140 (1967), abrogated by Califano v. Sanders, 430 U.S. 99 (1977).

250 Id.

2515 U.S.C. $§ 701(a)(2)(2011)$ 
Miller, and Montgomery have changed the discretionary nature of parole for juvenile parole hearings. No longer is the decision committed to the agency's discretion. Rather, the board is making a determination about the proportionality of the parole applicant's sentence. Particularly where constitutional claims are at stake, the Court is loath to "deny any judicial forum for a colorable constitutional claim." 252

The Supreme Court has recognized the problem of leaving the vindication of a constitutional right exclusively in the hands of a non-judicial actor. In 1986, the plurality in Ford $v$. Wainwright noted that the Court was aware of no circumstance in which "the vindication of a constitutional right [is] entrusted to the unreviewable discretion of an administrative tribunal."253 In that case, the Court was tasked with determining whether the Constitution forbids the execution of the insane. ${ }^{254}$ The Court held that such a practice ran afoul of the Eighth Amendment. ${ }^{255}$

The plurality opinion addressed the sufficiency of Florida's procedures for assessing competency, including the Governor's final approval of the competency determination. Florida had sentenced Alvin Ford to death in 1974. ${ }^{256}$ In 1982 he began to show signs of serious mental disturbance: he became obsessed with the Ku Klux Klan and was convinced that he was a target of a conspiracy by them and others to force him to kill himself; he believed that correctional officers were killing people and hiding the bodies in prison beds; he thought that his female relatives were being abused and tortured within the prison and that his friends and family were being held hostage in the prison; he wrote to the Attorney General of Florida to announce that he had ended the hostage crisis and "reported having appointed nine new justices to the Florida Supreme Court." 257 A psychiatrist hired by defense counsel found Ford suffered from a disease that resembled paranoid schizophrenia, and another doctor determined that Ford could not understand the connection between his crime and the death penalty-believing instead that he would not be executed because "he owned the prisons and could control the Governor through mind

252 Webster v. Doe, 486 U.S. 592, 603 (1988) (holding that statute did not preclude judicial review of respondent's claims that termination of employment violated his constitutional rights).

253 Ford v. Wainwright, 477 U.S. 399, 416 (1986).

254 Id. at 401.

255 Id. at 410.

256 Id. at 401

257 Id. at 402. 
waves." 258 Defense counsel initiated the state procedures for determining whether Ford was competent. ${ }^{259}$ Under these procedures, three psychiatrists interviewed Ford together for a half hour and filed three separate reports to the Governor. "One doctor concluded that Ford suffered from "psychosis with paranoia' but had 'enough cognitive functioning to understand the nature and the effects of the death penalty, and why it is to be imposed on him'"; the second doctor concluded that Ford was "psychotic" but knew "what can happen to him"; and the third "concluded that Ford had a 'severe adaptational disorder', but did 'comprehend his total situation including being sentenced to death,' and that Ford's disorder "seemed contrived."260 According to Florida procedures, the governor had final decision on the competency determination. He made his decision by signing a warrant for Ford's execution. ${ }^{261}$

It was this executive determination, without possibility of judicial review, to which the plurality opinion objected. After finding that the Eighth Amendment prohibits execution of a prisoner who is insane, the Court addressed whether the district court was required to hold an evidentiary hearing to determine Ford's sanity. ${ }^{262}$ The question hinged on whether the state court trier of fact had held a full hearing and "reliably found the relevant facts," in which case a district court hearing would not be required. ${ }^{263}$ The Court thus reviewed the adequacy of the state court procedures where a prisoner's competency determination is conducted "wholly within the executive branch." 264 The Court found that the procedures "fail[ed] to achieve even the minimal degree of reliability required for the protection of any constitutional interest." 265 In so concluding, the Court found that "[p]erhaps the most striking defect" in the procedures was "the placement of the decision wholly within the executive branch." 266 The court noted that delay of execution on the grounds of insanity was not traditionally an executive decision: "Thus, history affords no better basis than does logic for placing the final determination of a fact, critical to the trigger of a constitutional limitation upon the State's power, in

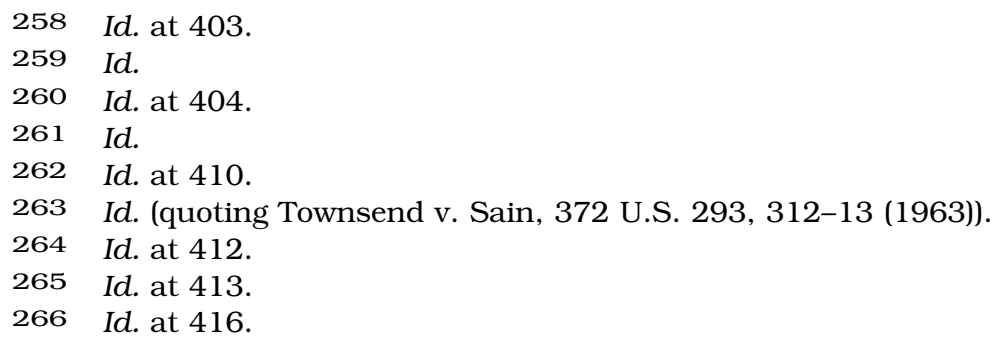


the hands of the State's own chief executive."267 The Court further asserted that this was an unprecedented case of shielding a constitutional decision from judicial review: "In no other circumstance of which we are aware is the vindication of a constitutional right entrusted to the unreviewable discretion of an administrative tribunal." 268 The plurality concluded that Florida's competency review procedures were insufficient.

More recently, in the denial of certiorari in a case challenging the constitutionality of Ohio's sentencing statute, Justice Sotomayor echoed this concern about insulating sentencing decisions from judicial review. In Campbell $v$. Ohio, Justice Sotomayor, writing separately, warned that Ohio's statute, which precludes review of a sentence imposed for murder or aggravated murder, "raises serious constitutional concerns."269 She elaborated: "Trial judges making the determination whether a defendant should be condemned to die in prison have a grave responsibility, and the fact that Ohio has set up a scheme under which those determinations 'cannot be reviewed' is deeply concerning." 270 Justice Sotomayor noted the parallels the Court has drawn between the death penalty and life without parole, and she reviewed the Court's decisions emphasizing the role of meaningful appellate review in ensuring the reliability of death sentences. ${ }^{271}$ In those cases, the Court stressed that appellate review "promotes reliability and consistency," 272 and ensures the penalty "is not imposed arbitrarily[,] . . . irrationally,"273 or "capriciously."274 While the Justice determined that the present case did not present the appropriate opportunity to address the issue of reviewability, she cautioned the Ohio courts to "be vigilant" in considering this question in the right case. ${ }^{275}$

As with the Eighth Amendment right at issue in Wainwright, the vindication of a parole applicant's constitutional

267 Id.

268 Id.

269138 S. Ct. 1059, 1059 (2018) (Sotomayor, J., concurring in denial of certiorari).

270 Id.

271 Id. at 1060.

272 Clemons v. Mississippi, 494 U.S. 738, 749 (1990).

273 Parker v. Dugger, 498 U.S. 308, 321 (1991).

274 Gregg v. Georgia, 428 U.S. 153, 195 (1976).

275 Campbell, 138 S. Ct. at 1061. See also Jones, 141 S. Ct. at 1340, n.10 (Sotomayor, J., dissenting) (rebuking the Court for "gestur[ing] at a potential lifeline from other [state] institutions": "The Eighth Amendment guarantees juvenile offenders like Jones a basic constitutional protection against disproportionate punishments. The Court should not leave the vindication of such important legal rights to others, or to chance."). 
rights and the determination of whether life without parole is a proportionate sentence cannot be foisted onto an administrative agency without judicial review. As Justice Sotomayor emphasized, meaningful appellate review serves an important role in ensuring that sentencing decisions are reliable and are not arbitrary or irrational. ${ }^{276}$ Given the parole board's constitutional obligation to assess what length of incarceration would be proportionate for the juvenile parole applicant, meaningful judicial review must be available to ensure the reliability of the parole board's decision.

\section{B. Review Beyond Procedural Due Process Compliance}

One argument that follows from the idea that Graham, Miller, and Montgomery constitutionalized parole is that the decisions created a liberty interest in parole for individuals who were under age eighteen at the time of the crime. This argument would trigger an analysis of the procedural protections due when the State purports to deprive people who were children at the time of the crime of this liberty interest. This is not a new theory, ${ }^{277}$ nor should it be overlooked. Such an analysis would lead to important procedural protections in juvenile parole hearings: the right to counsel, the right to present materials in support of parole, access to expert witnesses, and indeed the right to judicial review.

Yet, an assessment that focuses exclusively on the liberty interest in parole will not guarantee that the Eighth Amendment rights of people who committed crimes as children will be vindicated. Under a procedural due process analysis, there is no unfettered right to the liberty interest at stake. Rather, there is a right not to have the government deprive you of that protected interest without following a certain process. ${ }^{278}$ Conversely, the right to be free from disproportionate punishment is not so dependent. The government cannot impose punishment in violation of the Eighth Amendment simply because it

\footnotetext{
276 Id. at 1060.

277 See Bell, supra note 165, at 525-27 (analyzing how juvenile lifer jurisprudence challenges the Greenholtz paradigm, and arguing that juvenile lifer parole decisions are subject to constitutional due process protections); Drecun, supra note 165, at 731-33 (urging adaption of procedural due process principles to juvenile parole cases to require enhanced procedures); Russell, supra note 165, at 417-18 (articulating the argument that Graham "trigger[s] procedural due process protections" under Greenholtz, but concluding that analysis of rights for release under the Eighth Amendment rather than the Fourteenth "could lead to a more robust view of those rights").
}

278 See Morrissey v. Brewer, 408 U.S. 471, 484 (1972). 
has followed certain procedures. ${ }^{279}$ Procedural due process review asks whether a liberty interest might guarantee a certain process, but not a certain outcome. Under the Eighth Amendment, the outcome of the parole hearing matters.

In Greenholtz, while the Court determined there was no liberty interest in release on parole generally, the Court recognized that where a statute by its language provides for a liberty interest in parole, some procedural protections may be required. ${ }^{280}$ Because the Nebraska parole statute at issue in Greenholtz contained language that the board "shall order [a parole applicant's] release" unless certain conditions were met, the Court accepted that "the expectancy of release provided in this statue is entitled to some measure of constitutional protection." 281 The Court determined that the board's practices of allowing applicants a personal interview before the parole decision and of communicating the reasons for denial were sufficient for Fourteenth Amendment purposes. ${ }^{282}$

Juvenile parole applicants could assert a liberty interest in their parole release based on Graham, Miller, and Montgomery. Graham requires that juveniles convicted of nonhomicide offenses be given "a meaningful opportunity to obtain release based on demonstrated maturity and rehabilitation."283 Montgomery asserts that "[t]he opportunity for release will be afforded to those who demonstrate the truth of Miller's central intuition-that children who commit even heinous crimes are capable of change." 284 As the Greenholtz Court explained, "to obtain a protectable right . . . '[a person] must . . . have a legitimate claim of entitlement to it."'285 Graham and Montgomery's language arguably gives juvenile parole applicants a legitimate claim of entitlement to a meaningful opportunity for parole based on demonstrated growth and maturity.

Yet, under a procedural due process analysis alone, an individual imprisoned for a crime that occurred when they were a child might be offered some procedural protections, but they may still be forced to serve a disproportionate sentence even if

279 See, e.g., Graham v. Florida, 560 U.S. 48, 79 (2010) (determining that the Eighth Amendment requires a categorical rule against life without parole for juveniles convicted of nonhomicide offenses).

280 See Greenholtz v. Inmates of Neb. Penal \& Corr. Complex, 442 U.S. 1, 11-12 (1979).

281 Id.

282 Id. at 15-16.

283 Graham v. Florida, 560 U.S. 48, 75 (2010).

284 Montgomery v. Louisiana, 136 S. Ct. 718, 736 (2016).

285 Greenholtz, 442 U.S. at 7. 
they demonstrate rehabilitation. Procedural due process protections are intended to structure the board's exercise of discretion by providing an accurate record on which to base a decision. ${ }^{286}$ However, the parole board could have an entirely accurate record of the applicant's offense, background, youthrelated mitigating factors, and prison record-as well as evidence of growth and maturity-but could still render a decision denying parole. Procedural due process would have nothing to say about such a determination. ${ }^{287}$ And such an analysis ignores that no amount of procedure allows a state to require someone who was a child at the time of the crime to serve a disproportionate sentence.

A review of cases analyzing Graham and Montgomery claims under a procedural due process rubric demonstrates the limits of focusing exclusively on such an analysis. In Diatchenko, the Massachusetts Supreme Court addressed what constitutional protections were necessary for juvenile parole hearings. ${ }^{288}$ The court framed the question as "what is procedurally required in order to protect a juvenile homicide offender's expectation of 'a meaningful opportunity to obtain release based on demonstrated maturity and rehabilitation." 289 The court held that juvenile parole hearings required access to counsel, to funds for expert witnesses at the judge's discretion, and to judicial review. ${ }^{290}$ The court asserted an abuse of discretion standard for judicial review 291 and emphasized:

The purpose of judicial review here is not to substitute a judge's or an appellate court's opinion for the board's judgment . . . because this would usurp impermissibly the role of the board. Rather, judicial review is limited to the question whether the board has carried out its responsibility to take into account the . . . factors just described . . . 292

Because the court's focus was on the procedural requirements for a parole hearing, its understanding of the board's responsibility was correspondingly limited. The board must "take into

286 Morrissey v. Brewer, 408 U.S. 471, 484 (1972).

287 See, e.g., Swarthout v. Cooke, 562 U.S. 216, 222 (2011) (per curiam) (“Because the only federal right at issue is procedural, the relevant inquiry is what process [the parole applicants] received, not whether the state court decided the case correctly.").

288 Diatchenko v. Dist. Attorney for Suffolk Dist., 27 N.E.3d 349, 358 (Mass. 2015).

289 Id. (emphasis added) (quoting Graham v. Florida, 560 U.S. 48, 75 (2010)).

290 Id. at 361, 363, 365.

291 Id. at 366.

292 Id. at 365. 
account" youth and rehabilitation. ${ }^{293}$ But no result is guaranteed from such consideration. The board's determination will "constitute an abuse of discretion only if the board essentially failed to take these factors into account, or did so in a cursory way."294 This leaves open the possibility that the board will consider a juvenile parole applicant's youth and demonstrated maturity and rehabilitation, and yet deny parole based on, for example, the nature of the underlying offense. Massachusetts's standard of review would not remedy such an outcome. ${ }^{295}$

A New York appellate court also took up the issue of review for juvenile parole hearings. In Hawkins $v$. New York State Department of Corrections \& Community Supervision, the court determined that the parole board was required to consider the defendant's youth in making a release determination. ${ }^{296}$ In that case, the parole board had denied Hawkins nine times, most recently when he was fifty-four years old and had served thirty-six years of his sentence, because release "would so deprecate the seriousness of [his] offense as to undermine respect for the law."297 While the Hawkins court recognized that "petitioner has a substantive constitutional right not to be punished with a life sentence if the crime reflects transient immaturity," the court focused on consideration of youth as "the minimal procedural requirement necessary to ensure the substantive Eighth Amendment protections."298 Because the parole transcript in that case did not reflect that the board had considered youth in relation to the crime, the court held that Hawkins was entitled to a new parole hearing. ${ }^{299}$ The court's decision, though, does not inform the board's determination-only the factors it must consider along the way. Hawkins emphasizes procedures to the detriment of the outcome. As with Diatchenko, as long as the board considers youth, regardless of the outcome, the decision would stand.

A subsequent decision relying on Hawkins demonstrates the limitations of a bare requirement to consider youth. In

293 Id.

294 Id. at 366.

295 Sarah Mehta's comprehensive report on juvenile parole review reflects that in Massachusetts, since 2013, while the overall grant rate for juvenile lifers has been about 37\%, none of the fourteen juvenile lifers reviewed between August and December of 2015, after Diatchenko was decided, were granted parole. MEHTA, supra note 240 , at 50 .

29630 N.Y.S.3d 397, 398 (App. Div. 2016).

297 Id.

298 Id. (emphasis added).

299 Id. at 401. 
Allen v. Stanford, the New York Supreme Court, Appellate Division reviewed the case of Michael Allen, who was denied parole after he had served twenty-seven years in prison. ${ }^{300}$ The court cited Hawkins for the proposition that the board must consider "youth and its attendant characteristics."301 Yet, the court emphasized that the scope of review "is narrow" and that "[j]udicial intervention is warranted only when there is a showing of irrationality bordering on impropriety." 302 The court determined that the board had considered Allen's youth, but ultimately "placed greater emphasis on other factors, including the seriousness of petitioner's crimes and his history of unlawful and violent conduct." 303 The court highlighted the nature of the crime. ${ }^{304}$ The court did not fault the parole board for assigning greater weight to crime-related factors than to youthrelated factors in reaching its decision. ${ }^{305}$ Thus, under Hawkins, consideration of youth can be subsumed by the nature of the offense, and the board can deny parole for reasons unrelated to demonstrated maturity. ${ }^{306}$

The result of these decisions, which focus on the process rather than the outcome of the board's determination, is pro forma assessment of whether the board gave some consideration to youth. Such focus does not shed light on whether the parole applicant is in fact serving a disproportionate sentence. Analyzing the board's decision under the Eighth Amendment, not just its process, is necessary to ensuring that individuals who demonstrate rehabilitation are not held in prison in violation of the constitution. To be sure, if parole procedures entirely disallow consideration of youth, the board will be unable to make the constitutional determination with which it has been tasked. ${ }^{307}$ But, if review of parole decisions focuses exclusively on the procedures, it cannot ensure that the rights of

\footnotetext{
30078 N.Y.S.3d 445, 446-47 (App. Div. 2018).

301 Id. at 447.

302 Id. (internal citations omitted).

303 Id. at 448.

304 Id.

305 Id. at 450.

306 See also Wershe v. Combs, No. 1:12-CV-1375, 2016 WL 1253036, at *4-5 (W.D. Mich. Mar. 31, 2016) (granting parole board's motion for summary judgment because board had considered age and maturity; nothing more than consideration of youth was required).

307 Sarah Russell and Laura Cohen have highlighted the need for procedures that structure the board's ultimate determination in order to ensure that parole review is meaningful. Russell, supra note 165, at 415, 417; Cohen, supra note 165 , at $1087-88$.
} 
people incarcerated for offenses committed as juveniles have been vindicated.

\section{Proposed Standard for Judicial Review: Independent Review}

This Article proposes that a coherent reading of Graham, Miller, and Montgomery means that in juvenile parole hearings, a parole board must grant release unless it determines by clear and convincing evidence that the parole applicant has not matured and rehabilitated. The court should review the board's determination de novo to assess whether there was in fact sufficient evidence to support denial. While the court would not be conducting a rehearing, and would thus defer to credibility determinations by the parole board, the court would not be bound by the board's assessment of the evidence. ${ }^{308}$ This is a more stringent standard of review than that provided in most traditional parole hearings. Yet, such a heightened standard follows from the understanding of juvenile parole hearings as vindicating the Eighth Amendment right to a proportionate sentence; the reviewing court is being tasked with determining whether parole denial violates the applicant's constitutional rights. ${ }^{309}$

Some jurisdictions do subject parole board determinations to more rigorous scrutiny, even under the traditional parole model. An analysis of their reasoning is instructive as to what heightened review might look like in juvenile parole hearings. While these courts style their standards as abuse of discretion review, in practice they function like a stricter appraisal.

The New Jersey Supreme Court, while asserting that courts should not reverse parole board determinations unless they are "arbitrary or an abuse of discretion," 310 has described the court's review as requiring more exacting scrutiny. The court has interpreted the standard of review as requiring the reviewing court to consider "whether the record contains sub-

308 This may depend in part on which court hears the appeal. Jurisdictions vary in their mechanisms for appealing parole board decisions. In some states parole applicants file state habeas or post-conviction petitions, while in others they proceed through the normal appellate process. See Table in Appendix. Assuming robust parole board standards, a direct appeal is recommended. However, if the parole hearing did not allow for full development of the record, a habeas or post-conviction petition would allow for introduction of evidence directly before the reviewing court.

309 See Cohen, supra note 165, at 1088 (proposing less deferential standards of judicial review of parole board determinations).

310 Trantino v. N.J. State Parole Bd., 711 A.2d 260, 262-63 (N.J. 1998) (internal citation omitted). 
stantial evidence to support the findings on which the agency based its action." 311 This entails a determination of "whether the factual finding could reasonably have been reached on sufficient credible evidence in the whole record."312 New Jersey courts have applied this standard to reverse parole board determinations in many cases where the court disagreed with the sufficiency of the evidence upon which the board relied. ${ }^{313}$

In Trantino $v$. New Jersey State Parole Board, the New Jersey Supreme Court held that the parole board's decision was not supported by sufficient evidence, and remanded the case for rehearing. ${ }^{314}$ The parole applicant, who had been convicted of murder and sentenced to death, had his sentence commuted to life in prison after the New Jersey Supreme Court found the death penalty in that state unconstitutional. ${ }^{315}$ The parole board repeatedly denied Trantino parole, based largely on a requirement that he be placed in a halfway house. ${ }^{316}$ Trantino requested placement on multiple occasions only to be denied by prison officials. ${ }^{317}$ The board recognized that Trantino had "reached his rehabilitative potential within the confines of his current state prison setting," but maintained that he needed to be treated at a halfway house so that it could be determined whether or not he had been "fully rehabilitated."318 In reversing the parole board's decision, the court relied on the facts that Trantino had no disciplinary infractions in over two decades, that he had participated in dozens of work and recreation excursions to the community without incident, that he had completed several programs with positive reports from program supervisors, and that psychological reports provided favorable prognoses. ${ }^{319}$ The court rejected the board's finding that Trantino was avoiding responsibility for his crimes by claiming

\footnotetext{
311 Id. at 262.

312 Id. released).

314 Trantino, 711 A.2d at 261-62.

315 Id. at 262.

316 Id. at 264.

317 Id.

318 Id. at 265.

319 Id. at 266-67.
}

313 See, e.g., id. at 270 (remanding to the Parole Board for a determination that "must be based on whether there is a likelihood that Trantino will again engage in criminal activity," and on the defendant's age, successful completion of work detail, furlough, programming, education, lack of disciplinary infractions for almost three decades, stable support network, and positive psychological evaluations); Williams v. N.J. State Parole Bd., 763 A.2d 747, 751-52 (N.J. Super. Ct. App. Div. 2000) (reversing denial of parole because record did not contain sufficient credible evidence that the defendant would commit another crime if 
memory loss. ${ }^{320}$ The court found that evidence in the record showed that "Trantino's memory loss is consistent, long-standing and genuine," and that "his acknowledgment of responsibility is sincere and legitimate." ${ }^{21}$ Ultimately, the court held that "the Parole Board's final determination cannot be said to be supported by adequate findings of fact derived from sufficient credible evidence." 322

In Williams $v$. New Jersey State Parole Board, the New Jersey Court of Appeals reversed denial of parole to an individual who had been convicted of sexual assault of a child. ${ }^{323}$ The parole applicant had previously been granted parole, but release was revoked for failure to register as a sex offender and failure to gain approval of his change in residence and employment, despite the hearing officer's recommendation that the applicant continue on parole. ${ }^{324}$ A psychological report prepared for the subsequent parole hearing contradicted, without reference, an earlier report that Williams was appropriate for parole. The second report found that, "as long as Williams refuses to accept responsibility for his anti-social acts, he will be unable to progress in his rehabilitation and will remain a danger to society." 325 Relying in part on this new report, the parole board denied release. ${ }^{326}$ The reviewing court determined that the record did not "contain sufficient credible evidence that appellant would commit another crime if released," citing the fact that Williams did not commit any crime while previously on parole, and finding that the second psychological report "[was] entirely without foundation and [was] contradicted by the empirical evidence." 327 The court reversed the board's decision and concluded that Williams was entitled to immediate release because he was already less than a year away from his mandatory release date. ${ }^{328}$

Like New Jersey, Washington State relies on a seemingly heightened abuse of discretion standard. Washington's Indeterminate Sentence Review Board (ISRB) is the administrative body responsible for making discretionary parole determina-

\footnotetext{
320 Id. at 267-68.

321 Id. at 267.

322 Id. at 270.

323 Williams v. N.J. State Parole Bd., 763 A.2d 747, 748 (N.J. Super. Ct. App. Div. 2000).

324 Id. at 749.

325 Id. at 750.

326 Id. at 751.

327 Id. at 751-52.

328 Id. at 752.
} 
tions in that state. ${ }^{329}$ The courts in that state review ISRB decisions for abuse of discretion, which the Washington Supreme Court has interpreted to include decisions based on speculation and on the nature of the crime. ${ }^{330}$ In Dyer, the court held that the ISRB abused its discretion in denying release to a parole applicant serving a life sentence for two counts of rape. ${ }^{331}$ On each of three occasions that the ISRB considered Dyer for parole, he had been denied. ${ }^{332}$ The parole board's reason for the most recent denial was his failure to undergo sex offender treatment and an assessment that he "shows that he is an orderly person, careful in his work and is able to maintain himself within the institution[,] . . . precisely the behavior demonstrated in the crimes." ${ }^{333}$ The parole applicant had participated in numerous programs but did not complete sex offender therapy because he denied having committed the rapes. ${ }^{334}$ Before his most recent hearing, a psychological evaluation found him to be a "low risk to reoffend." 335 The court determined that the record did not support parole denial based on any of the factors listed in the governing regulations, that the board ignored the evidence, and that it based its decision instead on speculation and on the nature of the crime. ${ }^{336}$ The court emphasized that the ISRB may not "disregard the evidence presented at the hearing and base a decision on speculation and conjecture unsupported by evidence in the record."337 The court held that such a circumstance constitutes abuse of discretion, and remanded the case to the parole board for a new hearing. ${ }^{338}$

While New Jersey and Washington have applied heightened standards of review to traditional parole board hearings, California provides an example of a heightened standard of review in juvenile parole hearings. In 2018, the California Appellate Court determined that juvenile parole decisions should be subject to more stringent evaluation. ${ }^{339}$ In Palmer, the appellate court concluded that the juvenile parole applicant was

329 In re Dyer, 139 P.3d 320, 321 (Wash. 2006).

330 Id. at 325.

331 Id.

332 Id. at 321.

333 Id. at 322.

334 Id. at 321.

335 Id. at 324.

336 Id. at 323-24.

337 Id. at 321.

338 Id. at 325.

339 In re Palmer, 238 Cal. Rptr. 3d 59, 61 (Ct. App. 2018). The state supreme court ordered the decision not to be published after granting review in the case. 
entitled to a new parole hearing because the board failed "to comply with a statutory mandate to give 'great weight' to certain [youth-related] factors." 340 Palmer pled guilty to kidnapping for robbery and was sentenced to life in prison with the possibility of parole. ${ }^{341}$ He was denied parole ten times, and appealed the board's most recent denial, claiming, inter alia, that the board failed to give "great weight" to youth-related mitigation and identified no countervailing evidence of dangerousness that would outweigh the youth-related factors. ${ }^{342}$ In reversing the denial, the appellate court reasoned that "punishment cannot be imposed on a juvenile without giving 'great weight' to the factors that account for the diminished culpability of youth offenders and, therefore, might point to the constitutional disproportionality of the punishment." 343 Thus, the court concluded that this requirement "diminishes the Board's discretion to determine the bases upon which suitability or unsuitability for release may be determined." 344

The Palmer court created a heightened standard for juvenile parole hearings and for review of those decisions. The court explained that giving "great weight" to youth constrains the parole board's discretion and requires more than pro forma consideration of age:

Untenably, the Board treats the youth offender statutes as merely an exhortation for leniency, placing no limitation on the Board's unfettered discretion to decide whether a youthful offender remains an unreasonable risk of danger to society ... and requiring only that the prisoner's status as a youth offender be acknowledged for the record and taken into account in some undefined fashion. ${ }^{345}$

Rather, to give great weight to youth-related factors, "the Board must accept those factors as indicating suitability for release on parole absent substantial evidence of countervailing considerations indicating unsuitability," and the court would review to ensure substantial evidence supports denying release. ${ }^{346}$ Applying the articulated standard of review to Palmer's hearing, the court concluded that the board's decision "hardly ap-

Ultimately, the court dismissed the case after the state adopted new parole regulations.

340 Id.

341 Id.

342 Id.

343 Id. at 69.

344 Id.

345 Id. at 72.

346 Id. at 71. 
pear[ed] to reflect substantial evidence of countervailing considerations." ${ }^{447}$ The board's decision in that case hinged on an apparent determination of immaturity based on Palmer's improper use of a cell phone to contact his sister about his mother's death and on his gifting his girlfriend one of his Tshirts. ${ }^{348}$ The court vacated the parole board's decision and ordered a new hearing. ${ }^{349}$ The California Supreme Court granted review in Palmer in January 2019 but recently dismissed the case after new Board of Parole Hearings regulations were adopted. ${ }^{350}$

This Article proposes a standard of judicial review different from those described above. Because, unlike in Washington or New Jersey, juvenile parole hearings serve a constitutional function, courts must be able to review de novo parole board decisions. Deference may be owed to credibility determinations, but not to an assessment of whether the evidence overcomes the presumption that the juvenile parole applicant has matured and rehabilitated. Like California's scheme, this Article's proposal would allow the reviewing court to examine the evidence required to overcome the presumption of release. However, rather than adopt Palmer's "substantial evidence" standard, this Article proposes independent review to determine whether clear and convincing evidence rebuts the presumption. While the Palmer court used "substantial evidence" in the colloquial sense of significant or weighty, ${ }^{351}$ in the administrative law context such a standard reflects a requirement

\footnotetext{
347 Id. at 79 (internal quotations omitted).

348 Id. at $78-79$.

349 Id. at 79.

350 Palmer (William M.) on H.C., S252145 (Cal. dismissed Apr. 30, 2020). In its order of dismissal, the court noted that, as of January 2020, new regulations governing juvenile parole hearings had taken effect: "Because those regulations now affect all of the Board's parole suitability determinations for youth offenders, and because the regulations were not in effect when the Board held the parole hearing at issue in this matter, review in the above-captioned matter is hereby dismissed." Id. The Board's new regulations set forth a number of governing procedures for juvenile parole hearings. See CAL. CODE REGs. tit. 15, $\S \S 2440-2448$ (2020). The regulations codify the requirement that the board "give great weight to . . . (1) the diminished culpability of youth as compared to adults; (2) the hallmark features of youth; and (3) any subsequent growth and increased maturity of the inmate." CAL. CODE REGS. tit. $15 \S 2445$ (b) (2020). In addition, the regulations require denying parole when the parole board finds that "youth offender factors" are outweighed by "relevant and reliable evidence that the youth offender remains a current, unreasonable risk to public safety." Id. at (d). The regulations do not address judicial review of the board's decision.

351 See In re Palmer, 238 Cal. Rptr. 3d at 79.
} 
less than the weight of the evidence. ${ }^{352}$ As described in section III.D., supra, juvenile parole cases require a heightened standard of review.

Independent judicial review of juvenile parole determinations would ensure that, absent evidence they have failed to mature and rehabilitate, people who committed crimes as children will not be forced to spend the rest of their lives in prison. With a presumption of release, parole boards ought to be granting parole for most juvenile parole applicants, meaning the courts would not review most cases. Where parole is denied, however, de novo review tasks the courts with assessing whether there was indeed sufficient evidence to overcome the presumption that only rarely will a juvenile be irreparably corrupt. The courts, rather than parole boards, will be the ultimate deciders of whether the juvenile parole applicant is being forced to serve a disproportionate sentence. As in the states that have operated under a more stringent standard of review, the courts' review of juvenile parole determinations will force parole boards to rely on the evidence in the record and to take seriously the Supreme Court's judgment that the vast majority of people who commit crimes as children are capable of rehabilitation and deserving of lives outside of prison. ${ }^{353}$

\section{CONCLUSION}

Once an act of legislative and administrative grace, parole has taken on new significance in the context of juvenile parole hearings. Now tasked with rendering valid the life sentence of someone who committed a crime as a child, parole boards are making a constitutional determination. This constitutional charge has transformed parole into more than a purely discretionary assessment.

Yet, most parole systems do not have standards or procedures that address the constitutional task the Supreme Court has assigned to them. Parole applicants can demonstrate reform and rehabilitation but can still be forced to spend their lives in prison. And courts will have little to say about parole board decisions.

352 See, e.g., Consolo v. FMC, 383 U.S. 607, 619-20 (1966) (explaining that "substantial evidence," as set forth in the Administrative Procedure Act, is "something less than the weight of evidence").

353 See, e.g., Montgomery v. Louisiana, 136 S. Ct. 718, 734-36 (2016) (explaining that Miller's rule applies retroactively because there is a risk that "the vast majority of juvenile offenders" are facing unconstitutional punishment; describing Miller's conclusion that life without parole is disproportionate for the "vast majority" of people who committed crimes as children). 
The constitutionalization of parole for people who were under the age of eighteen at the time of their crimes requires new standards to ensure that these individuals' Eighth Amendment rights are vindicated. A presumption of release on parole, coupled with judicial review of the board's determination would help ensure Montgomery's promise that children who mature and rehabilitate are not forced to serve a disproportionate sentence. ${ }^{354}$

Such reforms provide an opportunity for states seeking to make real the protections of Graham and Miller and Montgomery for the many people for whom parole is the only hope of a life outside of prison. They provide a way to prevent that hope from being illusory, to offer instead a real guarantee of not spending the rest of one's life under a disproportionate sentence of incarceration.

The reforms proposed here are not the only method of ensuring that people who commit crimes as children do not serve disproportionate sentences. Changes must be made, and indeed are underway, to require that courts at the front end give credit to the mandate that we treat children differently at sentencing. ${ }^{355}$ Further reforms aimed at eliminating mandatory minimum sentences, decreasing sentence lengths, and keeping more children under the jurisdiction of juvenile courts are crucial. Additionally, making parole constitutionally meaningful for people who were children at the time of the crime does not address the many serious problems that follow from spending years, decades, or perhaps the rest of their lives under supervision. ${ }^{356}$ Indeed, ideally the sentence itself would change, not only the location in which it is served. But the reality for many

354 See id. at 736 ("[P]arole ensures that juveniles . . . who have since matured . . . will not be forced to serve a disproportionate sentence.").

355 See, e.g., CONN. GEN. STAT. § 54-91g (2015) (requiring courts at sentencing to consider defendant's age, "the hallmark features of adolescence," and the science that shows the difference between a child and adult's brain development); NEV. REV. STAT. ANN. § 176.017 (2017) (when sentencing someone convicted as an adult for an offense that occurred when they were under age eighteen, the court must "consider the differences between juvenile and adult offenders, including, without limitation, the diminished culpability of juveniles as compared to that of adults and the typical characteristics of youth").

356 In other words, this does not address the problem of mass supervision. See Gwen Robinson, Fergus McNeill \& Shadd Maruna, Punishment in Society: the Improbable Persistence of Probation and Other Community Sanctions and Measures, in THE SAGE HANDBOOK OF PUNISHMENT AND SOCIETY 321-40 (Jonathan Simon \& Richard Sparks eds., 2013); Michelle S. Phelps, Mass Probation: Toward a More Robust Theory of State Variation in Punishment, 19 PUNISHMENT \& SOC'Y 53, 53-55 (2017); Reuben Jonathan Miller \& Amanda Alexander, The Price of Carceral Citizenship: Punishment, Surveillance, and Social Welfare Policy in an Age of Carceral Expansion, 21 MICH. J. RACE \& L. 291, 291-94 (2016). 
individuals is that their sentence will not change, ${ }^{357}$ and that parole is their only chance to be released from prison. Moreover, recognizing the constitutionalization of parole offers a key normative shift in how we perceive the place and meaning of rehabilitation in criminal system reform more broadly. It puts rehabilitation at the center of the decision about how long someone ought to spend in prison, and asks decisionmakers to reflect not on the crime, but on the person before them.

Thousands of people have been sentenced to spend their lives behind bars for crimes committed when they were children, and many state parole boards have already been tasked with making constitutional decisions about how long these individuals should spend in prison. This Article proposes a way to ensure that this group receives meaningful review and sees the fulfillment of the Court's promise that the vast majority of people who were incarcerated as children will not be denied a life outside of prison.

357 And for some people even resentencing can only result in a sentence of life with the possibility of parole. See Russell, supra note 165, at 385 (explaining that in many states that have abolished mandatory life without parole for juveniles, under the new statutory schemes, a court may only impose either a sentence of life with parole or a sentence of life without parole). 


\section{Appendix}

\begin{tabular}{|c|c|c|c|c|c|}
\hline State & $\begin{array}{l}\text { Current } \\
\text { discre- } \\
\text { tionary } \\
\text { parole } \\
\text { scheme? }\end{array}$ & $\begin{array}{l}\text { Special } \\
\text { provi- } \\
\text { sions for } \\
\text { juvenile } \\
\text { parole? }\end{array}$ & $\begin{array}{l}\text { Mechanism } \\
\text { for judicial } \\
\text { review of } \\
\text { parole } \\
\text { board deci- } \\
\text { sion }\end{array}$ & $\begin{array}{l}\text { Standard of } \\
\text { review for } \\
\text { parole re- } \\
\text { lease deci- } \\
\text { sions }\end{array}$ & $\begin{array}{l}\text { Overview of ju- } \\
\text { dicial review of } \\
\text { parole decisions }\end{array}$ \\
\hline $\mathrm{AL}$ & $\begin{array}{l}\text { Yes with } \\
\text { some limi- } \\
\text { tations for } \\
\text { certain } \\
\text { violent } \\
\text { offenses }^{1}\end{array}$ & No & $\begin{array}{l}\text { Common } \\
\text { law petition } \\
\text { for writ of } \\
\text { certiorari to } \\
\text { trial court }^{2}\end{array}$ & $\begin{array}{l}\text { Arbitrary } \\
\text { and capri- } \\
\text { cious }\end{array}$ & $\begin{array}{l}\text { The courts will } \\
\text { review parole } \\
\text { board decisions } \\
\text { to determine if } \\
\text { board acted in an } \\
\text { arbitrary or ca- } \\
\text { pricious man- } \\
\text { ner. }{ }^{3} \text { There is no } \\
\text { liberty interest in } \\
\text { parole, and so no } \\
\text { due process re- } \\
\text { view. }{ }^{4} \text { The board } \\
\text { "must comply } \\
\text { with constitu- } \\
\text { tional require- } \\
\text { ments and may } \\
\text { not determine } \\
\text { parole eligibility } \\
\text { on improper } \\
\text { ground...parole } \\
\text { should not be } \\
\text { denied for false, } \\
\text { insufficient, or } \\
\text { capricious rea- } \\
\text { sons." } 5\end{array}$ \\
\hline $\mathrm{AK}$ & $\begin{array}{l}\text { Yes with } \\
\text { limited } \\
\text { excep- } \\
\text { tions }^{6}\end{array}$ & No & $\begin{array}{l}\text { Petition for } \\
\text { Postconvic- } \\
\text { tion relief }\end{array}$ & $\begin{array}{l}\text { Reasonable } \\
\text { basis / } \\
\text { abuse of } \\
\text { discretion }\end{array}$ & $\begin{array}{l}\text { "We review the } \\
\text { Parole Board's } \\
\text { discretionary au- } \\
\text { thority under the } \\
\text { reasonable basis } \\
\text { standard to in- } \\
\text { sure that the }\end{array}$ \\
\hline
\end{tabular}
27.4 .

ALA. CODE $\S \S 15-22-27,15-22-27.1,15-22-27.2,15-22-27.3,15-22-$

2 See, e.g., Ellard v. State, 474 So. 2d 743, 748 (Ala. Crim. App. 1984) (holding that writ of certiorari appropriate to review decisions of administrative parole board); Tedder v. Ala. Bd. Pardons \& Paroles, 677 So. 2d 1261 (Ala. Crim. App. 1996) (petition for writ of certiorari is correct method to challenge parole board's denial).

3 Andrus v. Lambert, 424 So.2d 5, 6 (Ala. Crim. App. 1982).

4 Id.

5 Id.

6 Alaska Stat. Ann. § 33.16.090. 


\begin{tabular}{|c|c|c|c|c|c|}
\hline State & $\begin{array}{l}\text { Current } \\
\text { discre- } \\
\text { tionary } \\
\text { parole } \\
\text { scheme? }\end{array}$ & $\begin{array}{l}\text { Special } \\
\text { provi- } \\
\text { sions for } \\
\text { juvenile } \\
\text { parole? }\end{array}$ & $\begin{array}{l}\text { Mechanism } \\
\text { for judicial } \\
\text { review of } \\
\text { parole } \\
\text { board deci- } \\
\text { sion }\end{array}$ & $\begin{array}{l}\text { Standard of } \\
\text { review for } \\
\text { parole re- } \\
\text { lease deci- } \\
\text { sions }\end{array}$ & $\begin{array}{l}\text { Overview of ju- } \\
\text { dicial review of } \\
\text { parole decisions }\end{array}$ \\
\hline & & & & & $\begin{array}{l}\text { Board's determi- } \\
\text { nations are sup- } \\
\text { ported by evi- } \\
\text { dence in the rec- } \\
\text { ord as a whole } \\
\text { and there is not } \\
\text { an abuse of dis- } \\
\text { cretion." } 7\end{array}$ \\
\hline $\mathrm{AZ}$ & $\begin{array}{l}\text { Not for } \\
\text { offenses } \\
\text { after } \\
1994,8 \\
\text { except for } \\
\text { juvenile } \\
\text { offenses }\end{array}$ & Yes $^{9}$ & $\begin{array}{l}\text { Special Ac- } \\
\text { tion to su- } \\
\text { perior } \\
\text { court }^{10}\end{array}$ & $\begin{array}{l}\text { Due process } \\
\text { compliance }\end{array}$ & $\begin{array}{l}\text { Before discre- } \\
\text { tionary parole } \\
\text { was abolished in } \\
1994, \text { the court } \\
\text { recognized a lib- } \\
\text { erty interest in } \\
\text { parole and at- } \\
\text { tendant need for } \\
\text { judicial review to } \\
\text { ensure due pro- } \\
\text { cess require- } \\
\text { ments were } \\
\text { met. } 11 \text { Otherwise, } \\
\text { actions of the } \\
\text { parole board "are } \\
\text { not, generally, } \\
\text { subject to judicial } \\
\text { review." } 12\end{array}$ \\
\hline AR & Yes $^{13}$ & Yes $^{14}$ & $\begin{array}{l}\text { Petition for } \\
\text { judicial re- } \\
\text { view }\end{array}$ & $\mathrm{N} / \mathrm{A}$ & $\begin{array}{l}\text { Arkansas law } \\
\text { precludes judicial } \\
\text { review of an ad- } \\
\text { ministrative ad- } \\
\text { judication re- }\end{array}$ \\
\hline
\end{tabular}

7 Duyck v. State, 2008 WL 269462 at *1 (Alaska Ct. App. 2008) (citing Covington v. State, 938 P.2d 1085, 1090-91 (Alaska App. 1997)).

8 See S.B. 1049, 41st Leg., 1st Reg. Sess. (Ariz. 1993).

9 See ARIZ. REV. STAT. ANN. \$§ 13-716, 41-1604.09 (making parole eligibility and parole classifications applicable to individuals who committed felony offenses before January 1, 1994 and to individuals subject to $\S 13-716$ juvenile parole statute).

10 See Sheppard v. Arizona Bd. of Pardons \& Paroles, 536 P.2d 196, 196197 (Ariz. 1975).

11 See Stewart v. Arizona Bd. of Pardons \& Paroles, 753 P.2d 1194, 1194 (Ariz. 1988).

12 Sheppard, 536 P.2d at 196.

13 See ARK. CODE ANN. § 16-93-614.

14 ARK. CODE 5-4-104(b), 5-4-602(3), 5-10-101(c), 5-10-102(c), 16-93612(e), 16-93-614, 16-93-618. 


\begin{tabular}{|c|c|c|c|c|c|}
\hline State & $\begin{array}{l}\text { Current } \\
\text { discre- } \\
\text { tionary } \\
\text { parole } \\
\text { scheme? }\end{array}$ & \begin{tabular}{|l|} 
Special \\
provi- \\
sions for \\
juvenile \\
parole?
\end{tabular} & $\begin{array}{l}\text { Mechanism } \\
\text { for judicial } \\
\text { review of } \\
\text { parole } \\
\text { board deci- } \\
\text { sion }\end{array}$ & $\begin{array}{l}\text { Standard of } \\
\text { review for } \\
\text { parole re- } \\
\text { lease deci- } \\
\text { sions }\end{array}$ & $\begin{array}{l}\text { Overview of ju- } \\
\text { dicial review of } \\
\text { parole decisions }\end{array}$ \\
\hline & & & & & $\begin{array}{l}\text { garding a prison- } \\
\text { er. }{ }^{15} \text { However, a } \\
\text { court will review } \\
\text { if the prisoner's } \\
\text { complaint asserts } \\
\text { an infringement } \\
\text { of constitutional } \\
\text { rights. }{ }^{16} \text { There is } \\
\text { no liberty interest } \\
\text { in parole release, } \\
\text { so no review for } \\
\text { violation of due } \\
\text { process. }{ }^{17}\end{array}$ \\
\hline $\mathrm{CA}$ & $\operatorname{Yes}^{18}$ & Yes $^{19}$ & $\begin{array}{l}\text { Habeas cor- } \\
\text { pus }\end{array}$ & $\begin{array}{l}\text { Some evi- } \\
\text { dence }\end{array}$ & $\begin{array}{l}\text { California courts } \\
\text { have recognized a } \\
\text { due process liber- } \\
\text { ty interest in pa- } \\
\text { role. }{ }^{20} \text { Courts } \\
\text { will review deci- } \\
\text { sions of the } \\
\text { board to deter- } \\
\text { mine whether } \\
\text { some evidence } \\
\text { supports the } \\
\text { board's deci- } \\
\text { sion. }{ }^{21} \text { The } \\
\text { standard requires } \\
\text { only "a modicum } \\
\text { of evidence."22 } \\
\text { A recent appel- } \\
\text { late court case, } \\
\text { ordered not to be } \\
\text { published after } \\
\text { the state su- } \\
\text { preme court } \\
\text { granted review, } \\
\text { relied on a }\end{array}$ \\
\hline
\end{tabular}

15 ARK. STAT. ANN. § 25-15-212.

16 Ruiz v. Felts, 512 S.W.3d 626, 628-29 (Ark. 2017); see also Clinton v. Bonds, 816 S.W. 2d 169, 171-72 (Ark. 1991) (constitutional questions are exception to statutory preclusion of judicial review for inmates in DOC custody).

17 Ruiz, 512 S.W.3d at 629.

18 Cal. Penal Code $\S 3046$.

19 SB 260; CAL. Penal Code $\S \S 3041,3046,4801,3051$

20 In re Rosenkrantz, 59 P.3d 174, 203 (Cal. 2002).

21 Id. at 205.

22 In re Shaputis, 265 P.3d 253, 265 (Cal. 2011). 


\begin{tabular}{|c|c|c|c|c|c|}
\hline State & $\begin{array}{l}\text { Current } \\
\text { discre- } \\
\text { tionary } \\
\text { parole } \\
\text { scheme? }\end{array}$ & $\begin{array}{l}\text { Special } \\
\text { provi- } \\
\text { sions for } \\
\text { juvenile } \\
\text { parole? }\end{array}$ & $\begin{array}{l}\text { Mechanism } \\
\text { for judicial } \\
\text { review of } \\
\text { parole } \\
\text { board deci- } \\
\text { sion }\end{array}$ & $\begin{array}{l}\text { Standard of } \\
\text { review for } \\
\text { parole re- } \\
\text { lease deci- } \\
\text { sions }\end{array}$ & $\begin{array}{l}\text { Overview of ju- } \\
\text { dicial review of } \\
\text { parole decisions }\end{array}$ \\
\hline & & & & & $\begin{array}{l}\text { heightened "sub- } \\
\text { stantial evidence" } \\
\text { standard for ju- } \\
\text { dicial review of } \\
\text { juvenile parole } \\
\text { hearings. } 23\end{array}$ \\
\hline $\mathrm{CO}$ & $Y_{e s}{ }^{24}$ & Yes $^{25}$ & $\mathrm{~N} / \mathrm{A}$ & $\mathrm{N} / \mathrm{A}$ & $\begin{array}{l}\text { The Colorado } \\
\text { Supreme Court } \\
\text { has held that } \\
\text { "the decision of } \\
\text { the board to } \\
\text { grant or deny is } \\
\text { not subject to } \\
\text { judicial review." } 26\end{array}$ \\
\hline CT & $\mathrm{Yes}^{27}$ & $\mathrm{Yes}^{28}$ & $\begin{array}{l}\text { Habeas cor- } \\
\text { pus if con- } \\
\text { stitutional } \\
\text { claim }\end{array}$ & $\mathrm{N} / \mathrm{A}$ & $\begin{array}{l}\text { Connecticut Gen- } \\
\text { eral Statutes pro- } \\
\text { vide that the de- } \\
\text { cision of the pa- } \\
\text { role board "shall } \\
\text { not be subject to } \\
\text { appeal." } 29 \text { The } \\
\text { Connecticut Su- } \\
\text { preme Court has } \\
\text { found no liberty } \\
\text { interest in re- } \\
\text { lease, and af- } \\
\text { firmed that the } \\
\text { decision to grant } \\
\text { parole is entirely } \\
\text { within the } \\
\text { board's discre- } \\
\text { tion. }{ }^{30} \text { However, } \\
\text { lower courts have } \\
\text { recognized that } \\
\text { the board's dis- }\end{array}$ \\
\hline
\end{tabular}

23 In re Palmer, 238 Cal. Rptr.3d 59, 71 (2018), review granted and ordered not to be published, Palmer, 433 P.3d 1 (Cal. 2019).

24 COLO. REV. STAT. § 17-22.5-403.

25 SB 16-180 (COLO. REv STAT §§ 17-22.5-403.7(2), 24-4.1-302.5(1)(j), 1734-101, -102, 17-22.5-403(4.5), 17-22.5-403.7(6).

26 In re Question Concerning State Judicial Review of Parole Denial Certified by U.S. Court of Appeals for Tenth Circuit, 610 P.2d 1340, 1341 (Col. 1980).

27 Conn. Gen. Stat. § 54-125a.

28 Id.

29 Id.

30 Baker v. Commissioner, 914 A.2d 1034, 1043 (Conn. 2007). 


\begin{tabular}{|c|c|c|c|c|c|}
\hline State & $\begin{array}{l}\text { Current } \\
\text { discre- } \\
\text { tionary } \\
\text { parole } \\
\text { scheme? }\end{array}$ & $\begin{array}{l}\text { Special } \\
\text { provi- } \\
\text { sions for } \\
\text { juvenile } \\
\text { parole? }\end{array}$ & $\begin{array}{l}\text { Mechanism } \\
\text { for judicial } \\
\text { review of } \\
\text { parole } \\
\text { board deci- } \\
\text { sion }\end{array}$ & $\begin{array}{l}\text { Standard of } \\
\text { review for } \\
\text { parole re- } \\
\text { lease deci- } \\
\text { sions }\end{array}$ & $\begin{array}{l}\text { Overview of ju- } \\
\text { dicial review of } \\
\text { parole decisions }\end{array}$ \\
\hline & & & & & $\begin{array}{l}\text { cretion does not } \\
\text { allow it to deny } \\
\text { parole for consti- } \\
\text { tutionally im- } \\
\text { permissible rea- } \\
\text { sons. }^{31}\end{array}$ \\
\hline $\mathrm{DE}$ & $\begin{array}{l}\text { Not for } \\
\text { offenses } \\
\text { after } \\
1990^{32}\end{array}$ & No & $\begin{array}{l}\text { Writ of } \\
\text { mandamus }\end{array}$ & \begin{tabular}{|l|} 
Statutory \\
and regula- \\
tory compli- \\
ance
\end{tabular} & $\begin{array}{l}\text { Granting parole } \\
\text { is within the } \\
\text { board's discre- } \\
\text { tion, and the } \\
\text { court's review is } \\
\text { limited to deter- } \\
\text { mining whether } \\
\text { the board fol- } \\
\text { lowed the proce- } \\
\text { dures in the gov- } \\
\text { erning statutes } \\
\text { and regula- } \\
\text { tions. }\end{array}$ \\
\hline $\mathrm{FL}$ & $\begin{array}{l}\text { Not for } \\
\text { offenses } \\
\text { after } \\
1983^{34}\end{array}$ & No & $\begin{array}{l}\text { Writ of } \\
\text { mandamus; } \\
\text { habeas cor- } \\
\text { pus }\end{array}$ & $\begin{array}{l}\text { Abuse of } \\
\text { discretion }\end{array}$ & $\begin{array}{l}\text { The board cannot } \\
\text { deny parole on } \\
\text { illegal grounds or } \\
\text { based on improp- } \\
\text { er considera- } \\
\text { tions. }{ }^{35} \text { The } \\
\text { court will review } \\
\text { for abuse of dis- } \\
\text { cretion. } 36\end{array}$ \\
\hline GA & Yes $^{37}$ & No & $\begin{array}{l}\text { Writ of } \\
\text { mandamus }\end{array}$ & $\begin{array}{l}\text { Gross abuse } \\
\text { of discretion }\end{array}$ & $\begin{array}{l}\text { The court has } \\
\text { recognized review } \\
\text { of the parole } \\
\text { board's decision } \\
\text { only where there } \\
\text { is gross abuse of } \\
\text { discretion. }{ }^{38}\end{array}$ \\
\hline
\end{tabular}

31 Cook v. Warden, 915 A.2d 935, 940 (Conn. Super. Ct. 2005).

32 Del. Admin Code. PAR 2.

33 Bradley v. Delaware Parole Bd., 460 A.2d 532, 534 (Del. 1983).

34 See Release Types: Parole, FLORIDA COMMISSION ON OFFENDER REVIEW, https://www.fcor.state.fl.us/release-types.shtml (last visited Nov. 2, 2020) [https://perma.cc/9N73-LBSY].

35 See Moore v. Fla. Parole \& Prob. Comm'n, 289 So. 2d 719, 720 (Fla. 1974).

36 Fla. Parole Comm'n v. Brown, 989 So. 2d 723, 724 (Fla. Dist. Ct. App. 2008).

37 GA. CODE ANN. § 42-9-45.

38 Justice v. State Bd. of Pardons \& Paroles, 218 S.E.2d 45, 46 (Ga. 1975). 


\begin{tabular}{|c|c|c|c|c|c|}
\hline State & $\begin{array}{l}\text { Current } \\
\text { discre- } \\
\text { tionary } \\
\text { parole } \\
\text { scheme? }\end{array}$ & $\begin{array}{l}\text { Special } \\
\text { provi- } \\
\text { sions for } \\
\text { juvenile } \\
\text { parole? }\end{array}$ & $\begin{array}{l}\text { Mechanism } \\
\text { for judicial } \\
\text { review of } \\
\text { parole } \\
\text { board deci- } \\
\text { sion } \\
\end{array}$ & $\begin{array}{l}\text { Standard of } \\
\text { review for } \\
\text { parole re- } \\
\text { lease deci- } \\
\text { sions }\end{array}$ & $\begin{array}{l}\text { Overview of ju- } \\
\text { dicial review of } \\
\text { parole decisions }\end{array}$ \\
\hline HI & Yes $^{39}$ & $\operatorname{Yes}^{40}$ & $\begin{array}{l}\text { Habeas cor- } \\
\text { pus }\end{array}$ & $\begin{array}{l}\text { Arbitrary } \\
\text { and capri- } \\
\text { cious abuse } \\
\text { of discretion }\end{array}$ & $\begin{array}{l}\text { Judicial review is } \\
\text { limited to "situa- } \\
\text { tions where the } \\
\text { parole board has } \\
\text { failed to exercise } \\
\text { any discretion at } \\
\text { all, or arbitrarily } \\
\text { and capriciously } \\
\text { abused its discre- } \\
\text { tion so as to give } \\
\text { rise to a due pro- } \\
\text { cess violation or } \\
\text { has otherwise } \\
\text { violated any con- } \\
\text { stitutional rights } \\
\text { of the prison- } \\
\text { er." } 41\end{array}$ \\
\hline ID & Yes $^{42}$ & No & $\begin{array}{l}\text { Habeas cor- } \\
\text { pus }\end{array}$ & $\begin{array}{l}\text { Rational } \\
\text { basis }\end{array}$ & $\begin{array}{l}\text { Courts will review } \\
\text { the parole } \\
\text { board's decision } \\
\text { only to determine } \\
\text { there is a rational } \\
\text { basis for the } \\
\text { board's deci- } \\
\text { sion. }{ }^{43} \text { However, } \\
\text { some courts have } \\
\text { recognized the } \\
\text { possibility of a } \\
\text { constitutional } \\
\text { claim based on } \\
\text { parole denial for } \\
\text { constitutionally } \\
\text { impermissible } \\
\text { reasons. }\end{array}$ \\
\hline IL & $\begin{array}{l}\text { Not for } \\
\text { offenses }\end{array}$ & Yes $^{46}$ & $\begin{array}{l}\text { Habeas cor- } \\
\text { pus for fed- }\end{array}$ & $\mathrm{N} / \mathrm{A}$ & $\begin{array}{l}\text { Illinois regula- } \\
\text { tions provide that }\end{array}$ \\
\hline
\end{tabular}

39 Haw. Rev. Stat. § 706-670.

40 Id. §§ 706-656(1), -657; Haw. Admin. Rules § 23-700-31(b).

41 Turner v. Haw. Paroling Auth., 1 P.3d 768, 776, 778 (Haw. Ct. App. 2000), as amended (May 9, 2000) (internal quotation marks omitted).

42 Idaho Code Ann. § 20-223.

43 Ybarra v. Dermitt, 657 P.2d 14, 15 (Idaho 1983); Burghart v. Carlin, 264 P.3d 71, 74 (Idaho Ct. App. 2011).

44 See Drennon v. Craven, 105 P.3d 694, 699 (Idaho Ct. App. 2004) (recognizing petitioner's constitutional claim that parole denial based on petitioner's legal actions against state officials would violate the First Amendment). 


\begin{tabular}{|c|c|c|c|c|c|}
\hline State & $\begin{array}{l}\text { Current } \\
\text { discre- } \\
\text { tionary } \\
\text { parole } \\
\text { scheme? }\end{array}$ & $\begin{array}{l}\text { Special } \\
\text { provi- } \\
\text { sions for } \\
\text { juvenile } \\
\text { parole? }\end{array}$ & $\begin{array}{l}\text { Mechanism } \\
\text { for judicial } \\
\text { review of } \\
\text { parole } \\
\text { board deci- } \\
\text { sion }\end{array}$ & $\begin{array}{l}\text { Standard of } \\
\text { review for } \\
\text { parole re- } \\
\text { lease deci- } \\
\text { sions }\end{array}$ & $\begin{array}{l}\text { Overview of ju- } \\
\text { dicial review of } \\
\text { parole decisions }\end{array}$ \\
\hline & \begin{tabular}{|l|} 
after \\
$1977^{45}$
\end{tabular} & & $\begin{array}{l}\text { eral consti- } \\
\text { tutional } \\
\text { claims }\end{array}$ & & $\begin{array}{l}\text { parole is an act of } \\
\text { grace and execu- } \\
\text { tive discretion, } \\
\text { not a right. }{ }^{47} \text { The } \\
\text { Illinois Supreme } \\
\text { Court has found } \\
\text { that the legisla- } \\
\text { ture intended the } \\
\text { parole board to } \\
\text { have complete } \\
\text { discretion, so a } \\
\text { court cannot } \\
\text { evaluate the } \\
\text { board's decision } \\
\text { to deny parole. }{ }^{48}\end{array}$ \\
\hline IN & \begin{tabular}{|l|} 
Not after \\
$1977-$ \\
moved to \\
fixed sen- \\
tences and \\
mandatory \\
parole $^{49}$
\end{tabular} & No & $\begin{array}{l}\text { Habeas cor- } \\
\text { pus }\end{array}$ & \begin{tabular}{|l|} 
Did board \\
act within \\
scope of its \\
powers; due \\
process \\
compliance
\end{tabular} & $\begin{array}{l}\text { Parole board has } \\
\text { almost absolute } \\
\text { discretion; the } \\
\text { courts will review } \\
\text { the board's deci- } \\
\text { sion only for pro- } \\
\text { cedural due pro- } \\
\text { cess compliance } \\
\text { and to determine } \\
\text { whether the } \\
\text { board acted with- } \\
\text { in the scope of its } \\
\text { powers. }{ }^{50} \\
\end{array}$ \\
\hline IA & Yes $^{51}$ & Yes $^{52}$ & $\begin{array}{l}\text { Petition for } \\
\text { judicial re- } \\
\text { view }\end{array}$ & $\begin{array}{l}\text { Unreasona- } \\
\text { ble, arbi- } \\
\text { trary, capri- } \\
\text { cious, or } \\
\text { abuse of } \\
\text { discretion }\end{array}$ & $\begin{array}{l}\text { The Iowa Su- } \\
\text { preme Court has } \\
\text { determined that } \\
\text { parole board de- } \\
\text { cisions qualify as } \\
\text { "other agency } \\
\text { action[s]" and are } \\
\text { therefore re- }\end{array}$ \\
\hline
\end{tabular}

46730 ILl. COMP. STAT. ANN. s 5/5-4.5-115 (parole review for persons under age 21 , effective June 2019 and applying prospectively).

45730 Ill. Comp. Stat. Ann. s 5/3-3-3.

47 ILL. ADMIN. CODE tit. 20 § 1610.50.

48 Hanrahan v. Williams, 673 N.E.2d 251, 253, 255 (Ill. 1996).

49 See Indiana Parole Board, INDIANA DEPARTMENT OF CORRECTION, https:// www.in.gov/idoc/2324.htm (last visited Sept. 16, 2019) [https://perma.cc/ U6KS-8Q4P].

50 Murphy v. Ind. Parole Bd., 397 N.E. 2d 259, 261 (Ind. 1979).

51 Iowa Code Ann. § 902.12.

52 IOWA CODE ANN. §§ 902.1, 903A.2. 


\begin{tabular}{|c|c|c|c|c|c|}
\hline State & $\begin{array}{l}\text { Current } \\
\text { discre- } \\
\text { tionary } \\
\text { parole } \\
\text { scheme? }\end{array}$ & $\begin{array}{l}\text { Special } \\
\text { provi- } \\
\text { sions for } \\
\text { juvenile } \\
\text { parole? }\end{array}$ & $\begin{array}{l}\text { Mechanism } \\
\text { for judicial } \\
\text { review of } \\
\text { parole } \\
\text { board deci- } \\
\text { sion }\end{array}$ & $\begin{array}{l}\text { Standard of } \\
\text { review for } \\
\text { parole re- } \\
\text { lease deci- } \\
\text { sions }\end{array}$ & $\begin{array}{l}\text { Overview of ju- } \\
\text { dicial review of } \\
\text { parole decisions }\end{array}$ \\
\hline & & & & & $\begin{array}{l}\text { viewed to deter- } \\
\text { mine whether } \\
\text { they are "unrea- } \\
\text { sonable, arbi- } \\
\text { trary, capricious, } \\
\text { or an abuse of } \\
\text { discretion."53 } \\
\end{array}$ \\
\hline KA & $\begin{array}{l}\text { Not for } \\
\text { offenses } \\
\text { after } \\
1993^{54}\end{array}$ & No & $\begin{array}{l}\text { Habeas cor- } \\
\text { pus }\end{array}$ & $\begin{array}{l}\text { Statutory } \\
\text { compliance, } \\
\text { arbitrary } \\
\text { and capri- } \\
\text { cious }\end{array}$ & $\begin{array}{l}\text { For individuals } \\
\text { sentenced before } \\
\text { 1993, the court's } \\
\text { review is limited } \\
\text { to determining } \\
\text { whether the } \\
\text { board complied } \\
\text { with applicable } \\
\text { statutes and } \\
\text { whether its deci- } \\
\text { sion was arbi- } \\
\text { trary and capri- } \\
\text { cious. }\end{array}$ \\
\hline $\mathrm{KY}$ & Yes $^{56}$ & No & $\begin{array}{l}\text { Petition for } \\
\text { declaratory } \\
\text { judgment }\end{array}$ & $\begin{array}{l}\text { Statutory } \\
\text { compliance }\end{array}$ & $\begin{array}{l}\text { Kentucky stat- } \\
\text { utes provide that } \\
\text { parole board de- } \\
\text { cisions "shall not } \\
\text { be reviewable" } \\
\text { except to deter- } \\
\text { mine statutory } \\
\text { compliance. } 57 \\
\text { The Kentucky } \\
\text { Supreme Court } \\
\text { has found no } \\
\text { liberty interest in } \\
\text { parole. }{ }^{58}\end{array}$ \\
\hline LA & Yes $^{59}$ & Yes $^{60}$ & $\mathrm{~N} / \mathrm{A}$ & $\mathrm{N} / \mathrm{A}$ & $\begin{array}{l}\text { Louisiana stat- } \\
\text { utes and parole } \\
\text { regulations pro- } \\
\text { vide that parole } \\
\text { is a discretionary }\end{array}$ \\
\hline
\end{tabular}

53 Johnson v. Dep’t of Corr., 635 N.W. 2d 487, 488, 489 (Iowa Ct. App. 2011) (citing Iowa Code $§ 17 A .19(10)$.

54 Kan. Stat. Ann. \& 22-3717.

55 Swisher v. Hamilton, 740 P.2d 95, 97 (Kan. App. 1987).

56 Ky. Rev. Stat. Ann. § 439.340.

57 Ky. Rev. Stat. Ann. § 439.330(3).

58 Belcher v. Ky. Parole Bd., 917 S.W. 2d 584, 587 (Ку. 1996).

59 LA. STAT. ANN. § 15:574.4 (2019).

60 La. Rev. Stat. Ann. § 15:574.4, Code of Crim. P. art. 878.1 (2017). 


\begin{tabular}{|c|c|c|c|c|c|}
\hline State & $\begin{array}{l}\text { Current } \\
\text { discre- } \\
\text { tionary } \\
\text { parole } \\
\text { scheme? }\end{array}$ & $\begin{array}{l}\text { Special } \\
\text { provi- } \\
\text { sions for } \\
\text { juvenile } \\
\text { parole? }\end{array}$ & $\begin{array}{l}\text { Mechanism } \\
\text { for judicial } \\
\text { review of } \\
\text { parole } \\
\text { board deci- } \\
\text { sion }\end{array}$ & $\begin{array}{l}\text { Standard of } \\
\text { review for } \\
\text { parole re- } \\
\text { lease deci- } \\
\text { sions }\end{array}$ & $\begin{array}{l}\text { Overview of ju- } \\
\text { dicial review of } \\
\text { parole decisions }\end{array}$ \\
\hline & & & & & $\begin{array}{l}\text { decision not sub- } \\
\text { ject to appeal. } 61\end{array}$ \\
\hline $\mathrm{ME}$ & \begin{tabular}{|l} 
Not for \\
offenses \\
after \\
$1976^{62}$
\end{tabular} & No & $\begin{array}{l}\text { Petition for } \\
\text { post- } \\
\text { conviction } \\
\text { review }\end{array}$ & Unclear & $\begin{array}{l}\text { Maine courts } \\
\text { have recognized a } \\
\text { right to petition } \\
\text { for post- } \\
\text { conviction review } \\
\text { of a parole } \\
\text { board's denial of } \\
\text { release, but the } \\
\text { standard of re- } \\
\text { view is unclear. }\end{array}$ \\
\hline $\mathrm{MD}$ & Yes $^{64}$ & No & $\begin{array}{l}\text { Petition for } \\
\text { review }\end{array}$ & $\begin{array}{l}\text { Arbitrary } \\
\text { and capri- } \\
\text { cious }\end{array}$ & $\begin{array}{l}\text { Courts have rec- } \\
\text { ognized common } \\
\text { law jurisdiction } \\
\text { to review the } \\
\text { board's action to } \\
\text { determine wheth- } \\
\text { er it was arbi- } \\
\text { trary and capri- } \\
\text { cious. } 65\end{array}$ \\
\hline MA & Yes $^{66}$ & Yes $^{67}$ & $\begin{array}{l}\text { Post- } \\
\text { conviction } \\
\text { motion }\end{array}$ & $\begin{array}{l}\text { Sufficiency } \\
\text { of the evi- } \\
\text { dence and } \\
\text { statutory } \\
\text { compliance }\end{array}$ & $\begin{array}{l}\text { Massachusetts } \\
\text { appears to accept } \\
\text { limited review of } \\
\text { parole board de- } \\
\text { cisions for suffi- }\end{array}$ \\
\hline
\end{tabular}

61 LA. Admin. Code tit. 22, Pt XI, § 705 (2020); LA. STAT. ANN. § 15:574.11 (2010); see also Sinclair v. Kennedy, 701 So. 2d 457, 462 (La. Ct. App. 1997) (no remedy for claim that board improperly denied parole).

62 ME. REv. STAT. ANN. tit. 34-A, §§ 5801, 5802 (2017).

63 See Mahaney v. State, 610 A.2d 738, 740-43 (Me. 1992) (allowing appeal via post-conviction review from denial of parole but holding that parole applicant was not entitled to appear personally at parole hearing, was not entitled to parole because of the board's failure to follow its own procedures, and was not denied equal protection); Fernald v. Me. State Parole Bd., 447 A.2d 1236, 1239 (Me. 1982) (holding that Maine's post-conviction review statute applies to review of parole denial for pre-Code sentences, but not clarifying the standard of review).

64 MD. Code AnN., Corr. Servs. § 7-301 (West 2017).

65 Pollock v. Patuxent Inst. Bd. of Rev., 751 A.2d 496, 499 (Md. 2000).

66 Mass. Gen. Laws Ann. ch. $127 \S 133$.

67 MASS. GEN. LAwS ANN. ch. $119 \S 72 \mathrm{~B}$ (persons between ages 14 and 18 are eligible for parole after 15 years); ch. $127 \S \S 133 \mathrm{~A}$ (providing right to counsel and funds for experts to parole applicants serving life sentences for crimes committed before age 18); see also Diatchenko v. Dist. Attorney for Suffolk Dist., 27 N.E. 3d 349, 356-67 (Mass. 2015) (requiring heightened procedural protections for juvenile parole hearings). 


\begin{tabular}{|c|c|c|c|c|c|}
\hline State & $\begin{array}{l}\text { Current } \\
\text { discre- } \\
\text { tionary } \\
\text { parole } \\
\text { scheme? }\end{array}$ & $\begin{array}{l}\text { Special } \\
\text { provi- } \\
\text { sions for } \\
\text { juvenile } \\
\text { parole? }\end{array}$ & $\begin{array}{l}\text { Mechanism } \\
\text { for judicial } \\
\text { review of } \\
\text { parole } \\
\text { board deci- } \\
\text { sion }\end{array}$ & $\begin{array}{l}\text { Standard of } \\
\text { review for } \\
\text { parole re- } \\
\text { lease deci- } \\
\text { sions }\end{array}$ & $\begin{array}{l}\text { Overview of ju- } \\
\text { dicial review of } \\
\text { parole decisions }\end{array}$ \\
\hline & & & & & $\begin{array}{l}\text { ciency of the evi- } \\
\text { dence and statu- } \\
\text { tory compliance, } \\
\text { as well as for } \\
\text { constitutional } \\
\text { claims. } 68\end{array}$ \\
\hline $\mathrm{MI}$ & Yes $^{69}$ & No & $\begin{array}{l}\text { Habeas cor- } \\
\text { pus }\end{array}$ & $\begin{array}{l}\text { Compliance } \\
\text { with govern- } \\
\text { ing law, } \\
\text { "competent, } \\
\text { material, } \\
\text { and sub- } \\
\text { stantial evi- } \\
\text { dence" (only } \\
\text { for claims } \\
\text { by State or } \\
\text { victim) }\end{array}$ & $\begin{array}{l}\text { Only the prose- } \\
\text { cutor or the } \\
\text { crime victim may } \\
\text { appeal the parole } \\
\text { board's deci- } \\
\text { sion. }{ }^{70} \text { Review } \\
\text { shall determine } \\
\text { whether the deci- } \\
\text { sion is authorized } \\
\text { by law and sup- } \\
\text { ported by "com- } \\
\text { petent, material, } \\
\text { and substantial } \\
\text { evidence."71 The } \\
\text { court will review } \\
\text { a prisoner's claim } \\
\text { that parole was } \\
\text { denied for an } \\
\text { unconstitutional } \\
\text { reason like race, } \\
\text { religion or na- } \\
\text { tional origin. }{ }^{72}\end{array}$ \\
\hline $\mathrm{MN}$ & $\begin{array}{l}\text { Not for } \\
\text { offenses } \\
\text { after } \\
1980^{73}\end{array}$ & No & $\begin{array}{l}\text { Habeas cor- } \\
\text { pus }\end{array}$ & $\begin{array}{l}\text { Clear abuse } \\
\text { of discre- } \\
\text { tion; due } \\
\text { process, } \\
\text { statutory, } \\
\text { constitu- } \\
\text { tional com- } \\
\text { pliance }\end{array}$ & $\begin{array}{l}\text { Traditionally, } \\
\text { parole was con- } \\
\text { sidered an act of } \\
\text { grace not subject } \\
\text { to judicial review, } \\
\text { but courts will } \\
\text { review to ensure } \\
\text { procedural due } \\
\text { process compli- }\end{array}$ \\
\hline
\end{tabular}

68 Greenman v. Mass. Parole Bd., 540 N.E.2d 1309, 1312-13 (Mass. 1989).

69 Mich. Comp. Laws Ann. § 791.234.

70 Mich. COMP. LAws ANN. \$791.234 (11); Morales v. Michigan Parole Bd., 676 N.W.2d 221, 227 (Mich. App. 2003).

71 Mich. Const. Art. $6 \S 28$.

72 Morales, 676 N.W.2d at 230.

73 See Community Supervision: How Supervision Works, Minnesota DEPARTMENT OF CORRECTIONS, available at https://mn.gov/doc/communitysupervision/supervision-101faq/ (last visited Sept. 16, 2019) [https:// perma.cc/4UZB-RXAY]. 


\begin{tabular}{|c|c|c|c|c|c|}
\hline State & $\begin{array}{l}\text { Current } \\
\text { discre- } \\
\text { tionary } \\
\text { parole } \\
\text { scheme? }\end{array}$ & $\begin{array}{l}\text { Special } \\
\text { provi- } \\
\text { sions for } \\
\text { juvenile } \\
\text { parole? }\end{array}$ & $\begin{array}{l}\text { Mechanism } \\
\text { for judicial } \\
\text { review of } \\
\text { parole } \\
\text { board deci- } \\
\text { sion }\end{array}$ & $\begin{array}{l}\text { Standard of } \\
\text { review for } \\
\text { parole re- } \\
\text { lease deci- } \\
\text { sions }\end{array}$ & $\begin{array}{l}\text { Overview of ju- } \\
\text { dicial review of } \\
\text { parole decisions }\end{array}$ \\
\hline & & & & & $\begin{array}{l}\text { ance and to re- } \\
\text { view allegations } \\
\text { of failure to follow } \\
\text { applicable statu- } \\
\text { tory and consti- } \\
\text { tutional princi- } \\
\text { ples. } \\
\text { review is limited } \\
\text { to determining if } \\
\text { there is a clear } \\
\text { abuse of discre- } \\
\text { tion. }{ }^{75}\end{array}$ \\
\hline MS & Yes $^{76}$ & No & $\begin{array}{l}\text { Petition to } \\
\text { show cause; } \\
\text { habeas cor- } \\
\text { pus }\end{array}$ & $\mathrm{N} / \mathrm{A}$ & $\begin{array}{l}\text { There is no right } \\
\text { of appeal from } \\
\text { the denial of pa- } \\
\text { role, but the } \\
\text { courts recognize } \\
\text { jurisdiction to } \\
\text { review constitu- } \\
\text { tional claims re- } \\
\text { garding the } \\
\text { board's deci- } \\
\text { sion. }^{77}\end{array}$ \\
\hline $\mathrm{MO}$ & Yes $^{78}$ & Yes $^{79}$ & $\begin{array}{l}\text { Petition for } \\
\text { declaratory } \\
\text { judgment; } \\
\text { petition for } \\
\text { trial de novo }\end{array}$ & $\begin{array}{l}\text { Statutory } \\
\text { compliance; } \\
\text { constitu- } \\
\text { tional com- } \\
\text { pliance }\end{array}$ & $\begin{array}{l}\text { Missouri statutes } \\
\text { provide that de- } \\
\text { nial of parole is } \\
\text { not reviewable. } 80 \\
\text { The courts will } \\
\text { only review the } \\
\text { board's decision } \\
\text { to ensure compli- } \\
\text { ance with the } \\
\text { governing parole } \\
\text { statutes, } 81 \\
\text { though some } \\
\text { cases suggest the }\end{array}$ \\
\hline
\end{tabular}

74 Kelsey v. State, 283 N.W. 2d 892, 894 (Minn. 1979).

75 Edstrom v. State, 378 N.W. 2d 90, 93 (Minn. Ct. App. 1985), affd, 386 N.W. 2d 708 (Minn. 1986).

76 Miss. Code. Ann. § 47-7-3.

77 Mangum v. Mississippi Parole Bd., 76 So.3d 762, 768-69 (Miss. Ct. App. 2011).

78 Mo. Ann. Stat. § 217.690.

79 Mo. ANN. STAT. §§ 558.047, 565.020, .030, .033, .034, .040.

80 MO. ANN. STAT. § $217.670(3)$.

81 Ladd v. Missouri Bd. of Prob. \& Parole, 299 S.W. 3d 33, 37 (Mo. Ct. App. 2009). 


\begin{tabular}{|c|c|c|c|c|c|}
\hline State & $\begin{array}{l}\text { Current } \\
\text { discre- } \\
\text { tionary } \\
\text { parole } \\
\text { scheme? }\end{array}$ & $\begin{array}{l}\text { Special } \\
\text { provi- } \\
\text { sions for } \\
\text { juvenile } \\
\text { parole? }\end{array}$ & $\begin{array}{l}\text { Mechanism } \\
\text { for judicial } \\
\text { review of } \\
\text { parole } \\
\text { board deci- } \\
\text { sion }\end{array}$ & $\begin{array}{l}\text { Standard of } \\
\text { review for } \\
\text { parole re- } \\
\text { lease deci- } \\
\text { sions }\end{array}$ & $\begin{array}{l}\text { Overview of ju- } \\
\text { dicial review of } \\
\text { parole decisions }\end{array}$ \\
\hline & & & & & $\begin{array}{l}\text { court will review } \\
\text { claims that pa- } \\
\text { role denial was } \\
\text { unconstitution- } \\
\text { al. }{ }^{82}\end{array}$ \\
\hline MT & $\mathrm{Yes}^{83}$ & No & $\begin{array}{l}\text { Habeas cor- } \\
\text { pus }\end{array}$ & $\begin{array}{l}\text { Statutory } \\
\text { compliance; } \\
\text { violation of } \\
\text { due process }\end{array}$ & $\begin{array}{l}\text { Montana recog- } \\
\text { nizes limited re- } \\
\text { view to ensure } \\
\text { compliance with } \\
\text { parole statutes, } \\
84 \\
\text { as well as with } \\
\text { procedural due } \\
\text { process require- } \\
\text { ments, at least in } \\
\text { pre-1989 cases } \\
\text { before the lan- } \\
\text { guage of the pa- } \\
\text { role statute was } \\
\text { amended. }{ }^{85}\end{array}$ \\
\hline $\mathrm{NE}$ & Yes $^{86}$ & Yes $^{87}$ & $\begin{array}{l}\text { Habeas cor- } \\
\text { pus, writ of } \\
\text { mandamus }\end{array}$ & $\begin{array}{l}\text { Due process } \\
\text { compliance; } \\
\text { statutory } \\
\text { compliance }\end{array}$ & $\begin{array}{l}\text { Courts will review } \\
\text { for compliance } \\
\text { with governing } \\
\text { parole statutes } \\
\text { and with re- } \\
\text { quirements of } \\
\text { procedural due }_{\text {process. }^{88}}\end{array}$ \\
\hline $\mathrm{NV}$ & Yes $^{89}$ & $\operatorname{Yes}^{90}$ & $\begin{array}{l}\text { Writ of } \\
\text { mandamus }\end{array}$ & $\begin{array}{l}\text { Statutory } \\
\text { and regula- } \\
\text { tory compli- } \\
\text { ance }\end{array}$ & $\begin{array}{l}\text { Nevada statutes } \\
\text { provide that pa- } \\
\text { role is an act of } \\
\text { grace entailing no }\end{array}$ \\
\hline
\end{tabular}

82 Cooper v. Missouri Bd. of Prob. \& Parole, 866 S.W. 2d 135, 137 (1993) (addressing prisoner's claim that denial of parole violated the Equal Protection Clause).

83 MonT. CODE ANN. § 46-23-201.

84 State v. Carson, 56 P.3d 844, 848 (Mont. 2002) (reviewing whether a claimed statutory right to counsel at parole hearing was denied).

85 Sage v. Gamble, 929 P.2d 822. 825 n.1 (Mont. 1996); West v. Mahoney, 22 P.3d 201, 201 (Mont. 2001).

86 Neb. Rev. Stat. Ann. § 83-1,110.

87 NEB. REV. STAT. ANN. §§ 28-105.02; § 83-1,110.04.

88 See Greenholtz v. Inmates of Nebraska Penal \& Corr. Complex, 442 U.S. 1, 12 (1979) (analyzing procedural due process claim); Van Ackeren v. Nebraska Bd. of Parole, 558 N.W.2d 48, 50, 53 (Neb. 1997) (discussing both statutory and procedural due process requirements).

89 Nev. Rev. Stat. Ann. § 213.120.

$90 \quad$ Nev. Rev. Stat. Ann. §§ 213.085, 213.12135, 213.1215. 


\begin{tabular}{|c|c|c|c|c|c|}
\hline State & $\begin{array}{l}\text { Current } \\
\text { discre- } \\
\text { tionary } \\
\text { parole } \\
\text { scheme? }\end{array}$ & \begin{tabular}{|l|} 
Special \\
provi- \\
sions for \\
juvenile \\
parole?
\end{tabular} & $\begin{array}{l}\text { Mechanism } \\
\text { for judicial } \\
\text { review of } \\
\text { parole } \\
\text { board deci- } \\
\text { sion }\end{array}$ & $\begin{array}{l}\text { Standard of } \\
\text { review for } \\
\text { parole re- } \\
\text { lease deci- } \\
\text { sions }\end{array}$ & $\begin{array}{l}\text { Overview of ju- } \\
\text { dicial review of } \\
\text { parole decisions }\end{array}$ \\
\hline & & & & & $\begin{array}{l}\text { right or liberty } \\
\text { interest. } 91 \text { How- } \\
\text { ever, courts will } \\
\text { review to ensure } \\
\text { the parole board } \\
\text { follows it govern- } \\
\text { ing statutes and } \\
\text { internal guide- } \\
\text { lines. }{ }^{92}\end{array}$ \\
\hline $\mathrm{NH}$ & Yes $^{93}$ & No & $\begin{array}{l}\text { Habeas cor- } \\
\text { pus }\end{array}$ & $\begin{array}{l}\text { Arbitrary } \\
\text { and capri- } \\
\text { cious - } \\
\text { modicum of } \\
\text { evidence; } \\
\text { constitu- } \\
\text { tional com- } \\
\text { pliance }\end{array}$ & $\begin{array}{l}\text { The court's re- } \\
\text { view of the parole } \\
\text { board's decision } \\
\text { is limited to } \\
\text { whether the deci- } \\
\text { sion was plainly } \\
\text { arbitrary, that is, } \\
\text { whether it is } \\
\text { supported by a } \\
\text { modicum of evi- } \\
\text { dence, or wheth- } \\
\text { er there was a } \\
\text { constitutional } \\
\text { violation. } 94\end{array}$ \\
\hline $\mathrm{NJ}$ & Yes $^{95}$ & Yes $^{96}$ & Appeal & $\begin{array}{l}\text { Arbitrary or } \\
\text { abuse of } \\
\text { discretion - } \\
\text { must be } \\
\text { substantial, } \\
\text { credible } \\
\text { evidence to } \\
\text { support } \\
\text { board's } \\
\text { findings }\end{array}$ & $\begin{array}{l}\text { Courts rely on an } \\
\text { arbitrariness or } \\
\text { abuse of discre- } \\
\text { tion standard for } \\
\text { review of parole } \\
\text { board decisions. } \\
\text { The standard has } \\
\text { been interpreted } \\
\text { to mean that } \\
\text { there must be } \\
\text { sufficient credible } \\
\text { evidence to sup- } \\
\text { port the finding } \\
\text { there is a sub- } \\
\text { stantial likeli- } \\
\text { hood the prisoner } \\
\text { will commit a }\end{array}$ \\
\hline
\end{tabular}

91 Nev. Rev. Stat. Ann. § 213.10705.

92 Anselmo v. Bisbee, 396 P.3d 848, 849 (Nev. 2017), reh'g denied (Nov. 16, 2017), reconsideration en banc denied (Jan. 19, 2018).

93 N.H. Rev. Stat. Ann. § 651-A:2.

94 Bussiere v. Cunningham, 571 A.2d 908, 913 (N.H. 1990).

95 N.J. STAT. ANN. § 30:4-123.51.

96 N.J. Stat. Ann. § 2C:11-3. 


\begin{tabular}{|c|c|c|c|c|c|}
\hline State & $\begin{array}{l}\text { Current } \\
\text { discre- } \\
\text { tionary } \\
\text { parole } \\
\text { scheme? }\end{array}$ & $\begin{array}{l}\text { Special } \\
\text { provi- } \\
\text { sions for } \\
\text { juvenile } \\
\text { parole? }\end{array}$ & $\begin{array}{l}\text { Mechanism } \\
\text { for judicial } \\
\text { review of } \\
\text { parole } \\
\text { board deci- } \\
\text { sion }\end{array}$ & $\begin{array}{l}\text { Standard of } \\
\text { review for } \\
\text { parole re- } \\
\text { lease deci- } \\
\text { sions }\end{array}$ & $\begin{array}{l}\text { Overview of ju- } \\
\text { dicial review of } \\
\text { parole decisions }\end{array}$ \\
\hline & & & & & $\begin{array}{l}\text { crime if re- } \\
\text { leased. } 97\end{array}$ \\
\hline $\mathrm{NM}$ & $\begin{array}{l}\text { After } \\
1979, \text { only } \\
\text { for those } \\
\text { serving life } \\
\text { sentenc- } \\
\text { es } 98\end{array}$ & No & $\mathrm{N} / \mathrm{A}$ & $\mathrm{N} / \mathrm{A}$ & $\begin{array}{l}\text { Parole is a matter } \\
\text { of grace resting } \\
\text { in discretion of } \\
\text { parole board, and } \\
\text { court will not } \\
\text { review the } \\
\text { board's deci- } \\
\text { sion. }^{99}\end{array}$ \\
\hline NY & Yes $^{100}$ & Yes $^{101}$ & $\begin{array}{l}\text { Article } 78 \\
\text { appeal of } \\
\text { agency deci- } \\
\text { sion }\end{array}$ & $\begin{array}{l}\text { Arbitrary or } \\
\text { capricious }\end{array}$ & $\begin{array}{l}\text { Courts will inter- } \\
\text { vene in the } \\
\text { board's decision } \\
\text { only when "there } \\
\text { is a showing of } \\
\text { irrationality bor- } \\
\text { dering on impro- } \\
\text { priety." } 102 \text { Review } \\
\text { is under arbitrary } \\
\text { and capricious } \\
\text { standard. }{ }^{103}\end{array}$ \\
\hline $\mathrm{NC}$ & $\begin{array}{l}\begin{array}{l}\text { Not for } \\
\text { offenses } \\
\text { after }\end{array} \\
1994^{104}\end{array}$ & No & $\begin{array}{l}\text { Habeas cor- } \\
\text { pus }\end{array}$ & $\begin{array}{l}\text { Due process } \\
\text { compliance; } \\
\text { constitu- } \\
\text { tional com- } \\
\text { pliance }\end{array}$ & $\begin{array}{l}\text { North Carolina } \\
\text { has recognized a } \\
\text { liberty interest- } \\
\text { and therefore a } \\
\text { right to due pro- } \\
\text { cess review-in } \\
\text { parole for people } \\
\text { whose offenses } \\
\text { occurred before } \\
1994.105 \text { The } \\
\text { court also recog- } \\
\text { nizes jurisdiction } \\
\text { to determine } \\
\text { whether the } \\
\text { board's action }\end{array}$ \\
\hline
\end{tabular}

97 Trantino v. New Jersey Parole Bd., 711 A.2d 260, 262 (N.J. 1998).

98 N.M. Stat. Ann. § 31-21-10.

99 Owens v. Swope, 287 P.2d 605, 612 (N.M. 1955).

100 N.Y. Penal Law § 70.40.

101 See Hawkins v. New York State Dep't of Corr. \& Cmty. Supervision, 140

A.D.3d 34, 38-40 (N.Y. App. Div. 2016).

102 Silmon v. Travis, 741 N.E.2d 501, 504 (N.Y. 2000).

103 Id.

104 Crimes-Convictions-Structured Sentencing, 1993 North Carolina Laws Ch. 538, at 2336 (H.B. 277).

105 Harwood v. Johnson, 388 S.E.2d 439, 444 (N.C. 1990). 


\begin{tabular}{|c|c|c|c|c|c|}
\hline State & $\begin{array}{l}\text { Current } \\
\text { discre- } \\
\text { tionary } \\
\text { parole } \\
\text { scheme? }\end{array}$ & $\begin{array}{l}\text { Special } \\
\text { provi- } \\
\text { sions for } \\
\text { juvenile } \\
\text { parole? }\end{array}$ & $\begin{array}{l}\text { Mechanism } \\
\text { for judicial } \\
\text { review of } \\
\text { parole } \\
\text { board deci- } \\
\text { sion }\end{array}$ & $\begin{array}{l}\text { Standard of } \\
\text { review for } \\
\text { parole re- } \\
\text { lease deci- } \\
\text { sions }\end{array}$ & $\begin{array}{l}\text { Overview of ju- } \\
\text { dicial review of } \\
\text { parole decisions }\end{array}$ \\
\hline & & & & & $\begin{array}{l}\text { exceeds constitu- } \\
\text { tional limits. }{ }^{106}\end{array}$ \\
\hline $\mathrm{ND}$ & Yes $^{107}$ & No & Unclear & $\begin{array}{l}\text { Statutory } \\
\text { compliance }\end{array}$ & $\begin{array}{l}\text { North Dakota } \\
\text { statutes provide } \\
\text { that orders of the } \\
\text { parole board are } \\
\text { not reviewable } \\
\text { except for statu- } \\
\text { tory compli- } \\
\text { ance. }{ }^{108}\end{array}$ \\
\hline $\mathrm{OH}$ & $\begin{array}{l}\begin{array}{l}\text { Not for } \\
\text { offenses } \\
\text { after }\end{array} \\
1996^{109}\end{array}$ & No & $\begin{array}{l}\text { Declaratory } \\
\text { judgment, } \\
\text { habeas cor- } \\
\text { pus }\end{array}$ & $\begin{array}{l}\text { Constitu- } \\
\text { tional com- } \\
\text { pliance }\end{array}$ & $\begin{array}{l}\text { The courts rec- } \\
\text { ognize challenges } \\
\text { to parole board } \\
\text { decisions on con- } \\
\text { stitutional } \\
\text { grounds only. }{ }^{110}\end{array}$ \\
\hline OK & Yes $^{111}$ & No & $\mathrm{N} / \mathrm{A}$ & $\mathrm{N} / \mathrm{A}$ & $\begin{array}{l}\text { Oklahoma parole } \\
\text { board decisions } \\
\text { are not subject to } \\
\text { Article II of the } \\
\text { Oklahoma Ad- } \\
\text { ministrative Pro- } \\
\text { cedures Act, } \\
\text { which provides } \\
\text { for judicial review } \\
\text { of final agency } \\
\text { orders; the courts } \\
\text { will not inter- } \\
\text { vene. }{ }^{112}\end{array}$ \\
\hline OR & $\begin{array}{l}\text { Not for } \\
\text { offenses } \\
\text { after } \\
1989,113\end{array}$ & Yes $^{114}$ & $\begin{array}{l}\text { Petition for } \\
\text { judicial re- } \\
\text { view }\end{array}$ & $\begin{array}{l}\text { Substantial } \\
\text { evidence; } \\
\text { regulatory, } \\
\text { statutory, }\end{array}$ & $\begin{array}{l}\text { Oregon statutes } \\
\text { provide for judi- } \\
\text { cial review of a } \\
\text { final parole board }\end{array}$ \\
\hline
\end{tabular}

106 Jones v. Keller, 698 S.E.2d 49, 54 (N.C. 2010).

107 N.D. CENT. CODE ANN. §§ 12.1-32-09.1, 12-59-09.

108 N.D. Cent. Code Ann. § 12-59-18.

109 Ohio Rev. Code Ann. § 2967.13.

110 Woodson v. Ohio Adult Parole Auth., 2002 WL 31722278, at *2 (Ohio App. 2002) ("Because appellant does not allege that his parole was denied for a constitutionally impermissible reason, the OAPA's decision to deny parole is not subject to judicial review."); Mayrides v. Ohio Adult Parole Auth., 1998 WL 211923 , at *2 (Ohio App. 1998).

111 OKLA. STAT. ANN. tit. 57 §32.7.

112 Shabazz v. Keating, 977 P.2d 1089, 1094 (Okla. 1999).

113 Or. Rev. Stat. Ann. § 144.050.

114 S. 1008, 80th Gen. Assemb., Reg. Sess. (Or. 2019). 


\begin{tabular}{|c|c|c|c|c|c|}
\hline State & \begin{tabular}{|l|} 
Current \\
discre- \\
tionary \\
parole \\
scheme?
\end{tabular} & \begin{tabular}{|l|} 
Special \\
provi- \\
sions for \\
juvenile \\
parole?
\end{tabular} & $\begin{array}{l}\text { Mechanism } \\
\text { for judicial } \\
\text { review of } \\
\text { parole } \\
\text { board deci- } \\
\text { sion }\end{array}$ & \begin{tabular}{|l|} 
Standard of \\
review for \\
parole re- \\
lease deci- \\
sions
\end{tabular} & $\begin{array}{l}\text { Overview of ju- } \\
\text { dicial review of } \\
\text { parole decisions }\end{array}$ \\
\hline & $\begin{array}{l}\text { except for } \\
\text { juvenile } \\
\text { offenses }\end{array}$ & & & $\begin{array}{l}\text { constitu- } \\
\text { tional com- } \\
\text { pliance }\end{array}$ & $\begin{array}{l}\text { order. }{ }^{115} \text { The } \\
\text { court will remand } \\
\text { the case if it finds } \\
\text { that the board's } \\
\text { exercise of discre- } \\
\text { tion was outside } \\
\text { that delegated to } \\
\text { it by law, was } \\
\text { inconsistent with } \\
\text { agency rules or } \\
\text { practice, or was } \\
\text { in violation of a } \\
\text { statutory or con- } \\
\text { stitutional provi- } \\
\text { sion; the court } \\
\text { will also remand } \\
\text { if it finds the } \\
\text { board's order is } \\
\text { not supported by } \\
\text { substantial evi- } \\
\text { dence, i.e. the } \\
\text { record would not } \\
\text { permit a reason- } \\
\text { able person to } \\
\text { make that find- } \\
\text { ing. } \\
\end{array}$ \\
\hline $\mathrm{PA}$ & Yes $^{117}$ & Yes $^{118}$ & N/A & $\mathrm{N} / \mathrm{A}$ & $\begin{array}{l}\text { A Pennsylvania } \\
\text { appellate court } \\
\text { has found there } \\
\text { is no right of ap- } \\
\text { peal from a deci- } \\
\text { sion of the board } \\
\text { denying parole, } \\
\text { including for } \\
\text { constitutional } \\
\text { claims. }{ }^{119} \\
\end{array}$ \\
\hline $\mathrm{RI}$ & Yes $^{120}$ & No & PCR & $\begin{array}{l}\text { Abuse of } \\
\text { discretion; } \\
\text { statutory } \\
\text { compliance }\end{array}$ & $\begin{array}{l}\text { State supreme } \\
\text { court decisions } \\
\text { seem to recognize } \\
\text { review under an }\end{array}$ \\
\hline
\end{tabular}

115 Or. Rev. Stat. Ann. § 144.335.

116 Or. Rev. Stat. Ann. § 183.482.

$11761 \mathrm{~Pa}$. Stat. and Cons. Stat. Ann. § 6137.

11818 Pa. Stat. and Cons. Stat. Ann. §§ 1102.1, 6139.

119 Weaver v. Pa. Bd. of Prob. \& Parole, 688 A.2d 766, 770-72 (Pa. Commw. Ct. 1997).

12013 R.I. GEN. LAWS ANN. §§ 13-8-8, 13-8-13. 


\begin{tabular}{|c|c|c|c|c|c|}
\hline State & $\begin{array}{l}\text { Current } \\
\text { discre- } \\
\text { tionary } \\
\text { parole } \\
\text { scheme? }\end{array}$ & $\begin{array}{l}\text { Special } \\
\text { provi- } \\
\text { sions for } \\
\text { juvenile } \\
\text { parole? }\end{array}$ & $\begin{array}{l}\text { Mechanism } \\
\text { for judicial } \\
\text { review of } \\
\text { parole } \\
\text { board deci- } \\
\text { sion }\end{array}$ & $\begin{array}{l}\text { Standard of } \\
\text { review for } \\
\text { parole re- } \\
\text { lease deci- } \\
\text { sions }\end{array}$ & $\begin{array}{l}\text { Overview of ju- } \\
\text { dicial review of } \\
\text { parole decisions }\end{array}$ \\
\hline & & & & & $\begin{array}{l}\text { abuse of discre- } \\
\text { tion standard to } \\
\text { determine if the } \\
\text { board exercised } \\
\text { discretion within } \\
\text { bounds set by } \\
\text { statute. }^{121}\end{array}$ \\
\hline $\mathrm{SC}$ & Yes $^{122}$ & No & $\begin{array}{l}\text { Appeal with } \\
\text { Administra- } \\
\text { tive Law } \\
\text { Court }\end{array}$ & $\begin{array}{l}\text { Arbitrary } \\
\text { and capri- } \\
\text { cious; stat- } \\
\text { utory com- } \\
\text { pliance }\end{array}$ & $\begin{array}{l}\text { The Administra- } \\
\text { tive Law Court } \\
\text { will review parole } \\
\text { board decisions } \\
\text { to determine if } \\
\text { the decision was } \\
\text { arbitrary and } \\
\text { capricious and } \\
\text { complied with } \\
\text { statutory re- } \\
\text { quirements. }{ }^{123} \\
\end{array}$ \\
\hline $\mathrm{SD}$ & $\begin{array}{l}\text { Yes pre- } \\
1996 \text { and } \\
\text { if denied } \\
\text { at initial } \\
\text { date post- } \\
1996^{124}\end{array}$ & No & $\mathrm{N} / \mathrm{A}$ & $\mathrm{N} / \mathrm{A}$ & $\begin{array}{l}\text { There is no ap- } \\
\text { peal from the } \\
\text { denial of the pa- } \\
\text { role board. }{ }^{125}\end{array}$ \\
\hline $\mathrm{TN}$ & Yes $^{126}$ & No & $\begin{array}{l}\text { Petition for } \\
\text { writ of certi- } \\
\text { orari (com- } \\
\text { mon law) }\end{array}$ & $\begin{array}{l}\text { Did board } \\
\text { exceed ju- } \\
\text { risdiction or } \\
\text { act illegally, } \\
\text { fraudulent- } \\
\end{array}$ & $\begin{array}{l}\text { Tennessee stat- } \\
\text { utes provide that } \\
\text { the board's deci- } \\
\text { sion shall not be } \\
\text { reviewable "if }\end{array}$ \\
\hline
\end{tabular}

121 See Estrada v. Walker, 743 A.2d 1026, 1031 (R.I. 1999); State v. Tillinghast, 609 A.2d 217, 218 (R.I. 1992); State v. Ouimette, 367 A.2d 704, 710 (R.I. 1976).

122 S.C. CODE ANN. § 24-21-610.

123 Cooper v. S.C. Dep’t of Prob., Parole \& Pardon Servs., 661 S.E.2d 106, 110, 112 (S.C. 2008).

124 See Frequent Questions: Parole, SOUTH DAKOTA DEPARTMENT OF CORRECTIONS, https://doc.sd.gov/about/faq/parole.aspx [https://perma.cc/JU7LJGJX, https://perma.cc/W3BD-QP6K] (last visited Sept 16. 2019). Under the system for crimes committed on or after July 1, 1996, prisoners will be released at their initial parole date unless they fail to complete their Individual Program Directive. Id. After the initial parole date, subsequent hearings are discretionary. Id.

125 Bergee v. South Dakota Bd. of Pardons \& Paroles, 608 N.W. 23 636, 641 (S.D. 2000).

126 TenN. CODE ANN. § 40-35-501. 


\begin{tabular}{|c|c|c|c|c|c|}
\hline State & $\begin{array}{l}\text { Current } \\
\text { discre- } \\
\text { tionary } \\
\text { parole } \\
\text { scheme? }\end{array}$ & $\begin{array}{l}\text { Special } \\
\text { provi- } \\
\text { sions for } \\
\text { juvenile } \\
\text { parole? }\end{array}$ & $\begin{array}{l}\text { Mechanism } \\
\text { for judicial } \\
\text { review of } \\
\text { parole } \\
\text { board deci- } \\
\text { sion }\end{array}$ & $\begin{array}{l}\text { Standard of } \\
\text { review for } \\
\text { parole re- } \\
\text { lease deci- } \\
\text { sions }\end{array}$ & $\begin{array}{l}\text { Overview of ju- } \\
\text { dicial review of } \\
\text { parole decisions }\end{array}$ \\
\hline & & & & $\begin{array}{l}\text { ly, or arbi- } \\
\text { trarily }\end{array}$ & $\begin{array}{l}\text { done according to } \\
\text { law." } 127 \text { However } \\
\text { courts have rec- } \\
\text { ognized limited } \\
\text { review to deter- } \\
\text { mine if the board } \\
\text { exceeded its ju- } \\
\text { risdiction, or act- } \\
\text { ed illegally, } \\
\text { fraudulently or } \\
\text { arbitrarily in the } \\
\text { manner in which } \\
\text { it reached its de- } \\
\text { cision. }{ }^{128} \text { Courts } \\
\text { may also review } \\
\text { claims that the } \\
\text { denial was un- } \\
\text { constitutional. }{ }^{129} \\
\end{array}$ \\
\hline $\mathrm{TX}$ & Yes $^{130}$ & No & $\begin{array}{l}\text { Habeas cor- } \\
\text { pus, writ of } \\
\text { mandamus }\end{array}$ & $\begin{array}{l}\text { Due process } \\
\text { compliance }\end{array}$ & $\begin{array}{l}\text { There is no re- } \\
\text { view of a parole } \\
\text { denial, though } \\
\text { courts may re- } \\
\text { view for proce- } \\
\text { dural due pro- } \\
\text { cess compli- } \\
\text { ance. }^{131}\end{array}$ \\
\hline UT & Yes $^{132}$ & No & $\begin{array}{l}\text { Petition for } \\
\text { extraordi- } \\
\text { nary relief, } \\
\text { habeas cor- } \\
\text { pus }\end{array}$ & $\begin{array}{l}\text { Due process } \\
\text { compliance }\end{array}$ & $\begin{array}{l}\text { Utah statutes } \\
\text { provide that deci- } \\
\text { sions of the pa- } \\
\text { role board are } \\
\text { final and not } \\
\text { subject to judicial } \\
\text { review. }{ }^{133} \text { Courts }\end{array}$ \\
\hline
\end{tabular}

127 TENn. CODE ANN. § 40-28-115(c).

128 Arnold v. Tennessee Bd. of Paroles, 956 S.W.2d 478, 480 (1997).

129 See, e.g., Swatzell v. Tennessee Board of Parole, 2019 WL $1533445 * 3-8$

(M.D. Tenn. 2019) (declining to dismiss claims that parole denial violated Ex Post Facto clause and Equal Protection, and permitting amendment to allege eighth amendment violation).

130 Tex. Gov't Code Ann. § 508.145.

131 See Ex parte Geiken, 28 S.W.3d 553, 559 (Tex. Crim. App. 2000); In re Texas Bd. of Pardons \& Paroles, 495 S.W.3d 554, 561-62 (Tex. App. 2016); Hills v. State, 2011 WL $5343690 * 2$ (Tex. App. 2011).

132 Utah Code Ann. § 77-27-5.

133 UTAH CODE ANN. § 77-27-5(3); see also Linden v. State, Dept. of Corr., 81 P.3d 802, 805 (2003) (no state or federal right to judicial review of initial parole release decision). 


\begin{tabular}{|c|c|c|c|c|c|}
\hline State & $\begin{array}{l}\text { Current } \\
\text { discre- } \\
\text { tionary } \\
\text { parole } \\
\text { scheme? }\end{array}$ & $\begin{array}{l}\text { Special } \\
\text { provi- } \\
\text { sions for } \\
\text { juvenile } \\
\text { parole? }\end{array}$ & $\begin{array}{l}\text { Mechanism } \\
\text { for judicial } \\
\text { review of } \\
\text { parole } \\
\text { board deci- } \\
\text { sion }\end{array}$ & $\begin{array}{l}\text { Standard of } \\
\text { review for } \\
\text { parole re- } \\
\text { lease deci- } \\
\text { sions }\end{array}$ & $\begin{array}{l}\text { Overview of ju- } \\
\text { dicial review of } \\
\text { parole decisions }\end{array}$ \\
\hline & & & & & $\begin{array}{l}\text { will only review } \\
\text { the process by } \\
\text { which the board } \\
\text { reaches its deci- } \\
\text { sion, but not the } \\
\text { decision itself. }{ }^{134}\end{array}$ \\
\hline VT & Yes $^{135}$ & Yes $^{136}$ & $\begin{array}{l}\text { Petition for } \\
\text { postconvic- } \\
\text { tion relief }\end{array}$ & $\mathrm{N} / \mathrm{A}$ & $\begin{array}{l}\text { Vermont appears } \\
\text { to prohibit judi- } \\
\text { cial review, ex- } \\
\text { cept perhaps for } \\
\text { alleged constitu- } \\
\text { tional viola- } \\
\text { tions. }^{137}\end{array}$ \\
\hline VA & $\begin{array}{l}\text { No, except } \\
\text { for juve- } \\
\text { niles, only } \\
\text { geriatric } \\
\text { parole for } \\
\text { offenses } \\
\text { after } \\
1995^{138}\end{array}$ & Yes $^{139}$ & Unclear & $\begin{array}{l}\text { Due process } \\
\text { compliance }\end{array}$ & $\begin{array}{l}\text { Courts have re- } \\
\text { viewed Virginia } \\
\text { parole board de- } \\
\text { cisions for proce- } \\
\text { dural due pro- } \\
\text { cess compli- } \\
\text { ance. }{ }^{140} \text { It is un- } \\
\text { clear what stand- } \\
\text { ard will be ap- } \\
\text { plied in reviewing } \\
\text { new juvenile pa- } \\
\text { role decisions. }\end{array}$ \\
\hline WA & $\begin{array}{l}\text { Not for } \\
\text { offenses } \\
\text { after } 1984\end{array}$ & Yes $^{142}$ & $\begin{array}{l}\text { Personal } \\
\text { restraint } \\
\text { petition }\end{array}$ & $\begin{array}{l}\text { Abuse of } \\
\text { discretion }\end{array}$ & $\begin{array}{l}\text { The court will } \\
\text { review parole } \\
\text { board decisions }\end{array}$ \\
\hline
\end{tabular}

134 Preece v. House, 886 P.2d 508, 512 (Utah 1994); see also Foote v. Utah Bd. of Pardons, 808 P.2d 734, 735-45 (Utah 1991) (due process review available); Labrum v. Utah Stat. Bd. of Pardons, 870 P.2d 902, 911 (Utah 1993) (due process requires timely disclosure of parole files).

135 VT. STAT. ANN. tit. 28, § 501.

136 VT. STAT. ANN. tit. 13, § 7045.

137 See Berard v. State of Vt. Parole Bd., 730 F.2d 71, 75 (Vt. 1984) (no liberty interest in parole warranting due process protection); In re Girouard, 102 A. 3d 1079, 1082 (Vt. 2014) (constitutional claims are reviewable by courts).

138 Criminal Sentencing Virginia Laws 2nd Sp. Sess. Ch. 1 (S.B. 3001); VA. CodE ANN. § 53.1-40.01; H.B. 35, 3030 Leg. Reg. Sess. (Va. 2020).

139 In February 2020 Virginia enacted legislation creating parole eligibility for individuals who were juveniles at the time of a felony offense or offenses and who have served at least 20 years of their sentence. H.B. 35, 2020 Leg., Reg. Sess. (Va. 2020). The legislation reinstates parole for people who were kids at the time of the crime in a state that had previously abandoned its discretionary parole system.

140 See Franklin v. Shields, 569 F.2d 784, 790 (4th Cir. 1977); Jackson v. Shields, 438 F. Supp. 183, 184 (W.D. Va. 1977). 


\begin{tabular}{|c|c|c|c|c|c|}
\hline State & $\begin{array}{l}\text { Current } \\
\text { discre- } \\
\text { tionary } \\
\text { parole } \\
\text { scheme? }\end{array}$ & $\begin{array}{l}\text { Special } \\
\text { provi- } \\
\text { sions for } \\
\text { juvenile } \\
\text { parole? }\end{array}$ & $\begin{array}{l}\text { Mechanism } \\
\text { for judicial } \\
\text { review of } \\
\text { parole } \\
\text { board deci- } \\
\text { sion }\end{array}$ & $\begin{array}{l}\text { Standard of } \\
\text { review for } \\
\text { parole re- } \\
\text { lease deci- } \\
\text { sions }\end{array}$ & $\begin{array}{l}\text { Overview of ju- } \\
\text { dicial review of } \\
\text { parole decisions }\end{array}$ \\
\hline & $\begin{array}{l}\text { except for } \\
\text { juvenile } \\
\text { offenses } \\
\text { and cer- } \\
\text { tain sex } \\
\text { offens- }_{\text {es }^{141}}\end{array}$ & & & & $\begin{array}{l}\text { for abuse of dis- } \\
\text { cretion to see if } \\
\text { the board failed } \\
\text { to follow its own } \\
\text { procedural rules } \\
\text { or acted without } \\
\text { consideration of } \\
\text { and in disregard } \\
\text { of the facts; } \\
\text { board may not } \\
\text { base its decision } \\
\text { on specula- } \\
\text { tion. } 143\end{array}$ \\
\hline WV & Yes $^{144}$ & Yes $^{145}$ & $\begin{array}{l}\text { Habeas cor- } \\
\text { pus }\end{array}$ & $\begin{array}{l}\text { Abuse of } \\
\text { discretion / } \\
\text { arbitrary } \\
\text { and capri- } \\
\text { cious; due } \\
\text { process } \\
\text { compliance }\end{array}$ & $\begin{array}{l}\text { West Virginia } \\
\text { recognizes a lib- } \\
\text { erty interest in } \\
\text { parole. Courts } \\
\text { will review the } \\
\text { board's decision } \\
\text { to see if the } \\
\text { board abused its } \\
\text { discretion by act- } \\
\text { ing arbitrarily } \\
\text { and capricious- } \\
\text { ly. }{ }^{146}\end{array}$ \\
\hline WI & $\begin{array}{l}\begin{array}{l}\text { Not for } \\
\text { offenses } \\
\text { after } \\
1999^{147}\end{array} \\
\end{array}$ & No & $\begin{array}{l}\text { Writ of cer- } \\
\text { tiorari }\end{array}$ & $\begin{array}{l}\text { Statutory } \\
\text { compliance; } \\
\text { arbitrary, } \\
\text { oppressive } \\
\text { or unrea- } \\
\text { sonable }\end{array}$ & $\begin{array}{l}\text { The court's re- } \\
\text { view is limited to } \\
\text { determining } \\
\text { whether the } \\
\text { board acted with- } \\
\text { in its jurisdiction } \\
\text { and according to } \\
\text { law; and whether } \\
\text { the board's ac- } \\
\text { tion was arbi- } \\
\text { trary, oppressive } \\
\text { or unreasonable } \\
\text { and represented }\end{array}$ \\
\hline
\end{tabular}

142 Wash. Rev. Code Ann. § 9.94A.730.

141 WASH. REV. CODE ANN. §§ 9.95.110-9.95.116, 9.95-190

143 In re Dyer, 139 P.3d 320, 323, 325 (Wash. 2006).

144 W. Va. Code Ann. § 62-12-13.

145 W. VA. CODE ANN. §§ 61-11-23, 62-12-13b.

146 Tasker v. Mohn, 267 S.E.2d 183, 190-91 (W. Va. 1980).

147 See Wisconsin Parole Commission, STATE OF Wisconsin DEPARTMENT OF CORRECTIONS, https://doc.wi.gov/Pages/AboutDOC/ParoleCommission.aspx [https://perma.cc/K8M8-UQRX] (last visited Sept. 16, 2019). 


\begin{tabular}{|l|l|l|l|l|l|}
\hline State & $\begin{array}{l}\text { Current } \\
\text { discre- } \\
\text { tionary } \\
\text { parole } \\
\text { scheme? }\end{array}$ & $\begin{array}{l}\text { Special } \\
\text { provi- } \\
\text { sions for } \\
\text { juvenile } \\
\text { parole? }\end{array}$ & $\begin{array}{l}\text { Mechanism } \\
\text { for judicial } \\
\text { review of } \\
\text { parole } \\
\text { board deci- } \\
\text { sion }\end{array}$ & $\begin{array}{l}\text { Standard of } \\
\text { review for } \\
\text { parole re- } \\
\text { lease deci- } \\
\text { sions }\end{array}$ & $\begin{array}{l}\text { Overview of ju- } \\
\text { dicial review of } \\
\text { parole decisions }\end{array}$ \\
\hline & & & & $\begin{array}{l}\text { its will and not } \\
\text { its judgment; and } \\
\text { whether the evi- } \\
\text { dence reasonably } \\
\text { calls into ques- } \\
\text { tion the deci- } \\
\text { sion. }{ }^{148}\end{array}$ \\
\hline WY & Yes ${ }^{149}$ & Yes ${ }^{150}$ & N/A & N/A & $\begin{array}{l}\text { Wyoming stat- } \\
\text { utes exempt pa- } \\
\text { role board deci- } \\
\text { sions from review } \\
\text { under the state } \\
\text { Administrative } \\
\text { Procedure Act. }\end{array}$ \\
\hline
\end{tabular}

148 State v. Goulette, 222 N.W. 2d 622, 626 (Wis. 1974).

149 Wyo. Stat. Ann. § 7-13-402.

150 WYO. STAT. ANN. §§ 6-2-101(b), 6-2-306, 6-10-201(b), 6-10-301, 7-13- 